Cecilia Rezende da Silva Cunha

\title{
Perda perinatal: um estudo sobre luto e vínculo
}

Dissertação de Mestrado

Dissertação apresentada como requisito parcial para obtenção do grau de Mestre pelo Programa de PósGraduação em Psicologia (Psicologia Clínica) do Departamento de Psicologia da PUC-Rio.

Orientadora: Profa. Luciana Fontes Pessôa

Rio de Janeiro, Março de 2021 
Pontifícia Universidade Católica

Cecilia Rezende da Silva Cunha

\section{Perda perinatal: um estudo sobre luto e vínculo}

Dissertação apresentada como requisito parcial para obtenção do grau de Mestre pelo Programa de Pós-Graduação em Psicologia (Psicologia Clínica) da PUC-Rio. Aprovada pela Comissão Examinadora abaixo.

Profa. Luciana Fontes Pessôa

Orientadora

Departamento de Psicologia - PUC-Rio

Profa. Monah Winograd

Departamento de Psicologia - PUC-Rio

Prof ${ }^{\mathrm{a}}$ Maria Helena Pereira Franco Departamento de Psicologia - PUC-SP

Rio de Janeiro, 19 de março de 2021 
Todos os direitos reservados. É proibida a reprodução total ou parcial do trabalho sem autorização da universidade, da autora e da orientadora.

\section{Cecilia Rezende da Silva Cunha}

Psicóloga graduada pela PUC-Rio (2005). Especialista em Psicologia Clínica pela PUC-Rio (2007). Especialista em Psicologia Oncológica pelo INCA (2009). Aprimoramento em Teoria, Pesquisa e Intervenção em Luto Pelo Instituto 4 Estações (2012). Aprimoramento em Teoria do Apego pelo Instituto 4 Estações (2015). Sócia fundadora do Instituto Entrelaços de Psicologia (2012). Professora e supervisora do curso de especialização em Psico-Oncologia da PUC-Rio. Atua na área de Psicologia Clínica, com interesse nos temas: luto, perda, adoecimento, terminalidade, psico-oncologia.

\section{Ficha Catalográfica}

Cunha, Cecilia Rezende da Silva

Perda perinatal : um estudo sobre luto e vínculo / Cecilia Rezende da Silva Cunha ; orientadora: Luciana Fontes Pessoa. - 2021. 140 f. : il. color. ; $30 \mathrm{~cm}$

Dissertação (mestrado)-Pontifícia Universidade Católica do Rio de Janeiro, Departamento de Psicologia, 2021.

Inclui bibliografia

1. Psicologia - Teses. 2. Luto. 3. Perda perinatal. 4. Vínculo. 5. Apego. 6. Interações iniciais. I. Pessoa, Luciana Fontes. II. Pontifícia Universidade Católica do Rio de Janeiro. Departamento de Psicologia. III. Título. 
Dedico esta Dissertação a todos os bebês que não puderam ficar neste mundo, mas que se fazem tão presentes na vida de suas famílias. 


\section{Agradecimentos}

À Luciana Fontes Pessôa, minha orientadora, por todo cuidado e atenção no desenvolvimento desse trabalho. Agradeço por suas contribuições, seu incentivo e confiança do início ao fim!

À CAPES e à PUC-Rio pelos auxílios concedidos, sem os quais este trabalho não poderia ter sido realizado.

À profa. Dra. Maria Helena Pereira Franco, que esteve presente na qualificação e aceitou o convite de participar mais uma vez. Agradeço por sua presença acadêmica e afetiva na minha vida!

À profa. Dra. Monah Winograd, pela presença na banca e pela disponibilidade em avaliar minha dissertação.

Aos professores da PUC-Rio pelo espaço para aprendizagem e discussão.

Às mães que aceitaram fazer parte desse trabalho, por dividirem suas histórias de amor e dor e pelo desejo genuíno de contribuição com a pesquisa.

Aos meus pacientes, por me permitirem acompanhar suas trajetórias de construção de sentido.

À Bruna Soares, encontro significativo dessa jornada acadêmica, por dividir aprendizados e angústias.

À Isabela Cristina Gonçalves Sena, por sua gentileza e generosidade.

À Erika Pallottino, sócia e amiga, por ser sempre incentivo e asa para meus voos.

Ao Instituto Entrelaços, minha segunda casa, por possibilitar o meu cuidado aos enlutados.

À Jessica e Eliana, pelo imprescindível apoio técnico.

Às minhas grandes e queridas amigas, pela presença constante e por todos os momentos de descontração.

Ao Felipe, parceiro e amor da vida, que mais uma vez esteve junto nessa caminhada. Aos meus filhos, Isabel e Gustavo, por me ensinarem todos os dias sobre amor e cuidado.

À minha grande e linda família, porto e base seguros. Sem vocês não seria possível! O presente trabalho foi realizado com apoio da Coordenação de Aperfeiçoamento de Pessoal de Nível Superior - Brasil (CAPES) - Código de Financiamento 001. 


\section{Resumo}

Cunha, Cecilia Rezende da Silva; Pessôa, Luciana Fontes. Perda perinatal: um estudo sobre luto e vínculo. Rio de Janeiro, 2021. 140p. Dissertação de Mestrado - Programa de Pós-Graduação em Psicologia Clínica, Pontifícia Universidade Católica do Rio de Janeiro.

O luto vivenciado a partir de uma perda gestacional ou neonatal apresenta características e reações semelhantes a outros tipos de luto, entretanto, muitas vezes é não-reconhecido (Doka, 1989). Espera-se que a chegada de um novo bebê seja capaz de "resolver" o luto. O vínculo entre cuidador primário e a criança é fundamental para a sobrevivência física e emocional e, por isso, essa relação inicial é tão importante para o desenvolvimento de todos os indivíduos. O objetivo da pesquisa foi investigar as repercussões da perda gestacional ou neonatal prévia no processo de construção do vínculo da mãe com o bebê que nasce durante o processo de luto. $\mathrm{O}$ estudo de cunho qualitativo entrevistou 17 mulheres que tiveram ao menos uma perda gestacional ou neonatal e tiveram um novo bebê após a perda. Os resultados demonstraram a necessidade das mães explicarem detalhadamente a experiência de perda, em uma possível busca de construção de sentido. A tristeza e a culpa foram identificadas como principais reações frente ao luto que foi vivenciado de maneira silenciosa. A maioria das mães referiu medo relacionado à gravidez subsequente e à vinculação com o bebê durante o período gestacional. O contato corporal foi o principal sistema parental identificado nas interações. O trabalho concluiu que apesar de serem comuns e frequentes e, muitas vezes nãoreconhecidas, perdas perinatais são vividas de maneira singular, repercutem nas interações e não são resolvidas com o nascimento de um novo bebê. Acredita-se que esse estudo possa contribuir para a legitimação e o reconhecimento do luto por perda gestacional e neonatal e para a maior atenção às interações iniciais nesse contexto.

\section{Palavras-chave}

Luto; perda perinatal; vínculo; apego; interações iniciais; desenvolvimento inicial. 


\section{Abstract}

Cunha, Cecilia Rezende da Silva; Pessôa, Luciana Fontes (Advsor). Perinatal loss: a study on grieving and bonding. Rio de Janeiro, 2021. 140p. Dissertação de Mestrado - Programa de Pós-Graduação em Psicologia Clínica, Pontifícia Universidade Católica do Rio de Janeiro.

The grief experienced after a miscarriage, stillbirth, or neonatal loss presents characteristics and reactions similar to other types of bereavement although it is often unrecognized (Doka, 1989). It is expected that the arrival of a new baby should be able to "resolve" the grief. The bond between the primary caregiver and the child is fundamental for physical and emotional survival and that is why this initial relationship is so important for the development of all individuals. The objective of this research was to investigate the repercussions of a previous perinatal loss in the process of building the mother's bond with the baby born during the grieving process. The qualitative study interviewed 17 women who had at least one perinatal loss and had a new baby after such loss. The results demonstrated the need for mothers to explain the loss experience in detail, possibly searching for the meaning reconstruction. Sadness and guilt were identified as the main reactions to the grief, which was experienced silently. Most mothers reported fear related to the subsequent pregnancy and to bonding with the baby during the gestational period. Body contact was the main parental system identified in the interactions. The study concluded that, although common and frequent and, many times, unrecognized, perinatal losses are experienced in a unique way, impact on interactions, and are not necessarily resolved with the birth of a new baby. We believe that this study may contribute to the legitimacy and recognition of mourning from perinatal loss and to greater attention to the initial interactions in this context.

\section{Keywords}

Grief; bereavement; perinatal loss; bonding; attachment; early interaction; initial development. 


\section{Sumário}

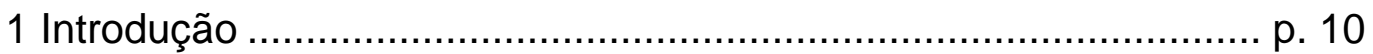

2 Construção de vínculo e interações iniciais .................................. p. 12

30 processo de luto …............................................................... p. 24

4 Perda gestacional e neonatal e luto …….................................. p. 34

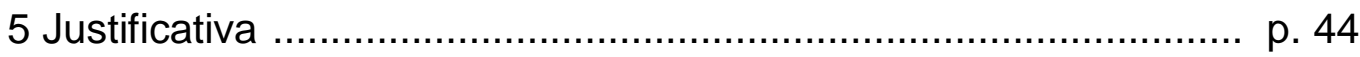

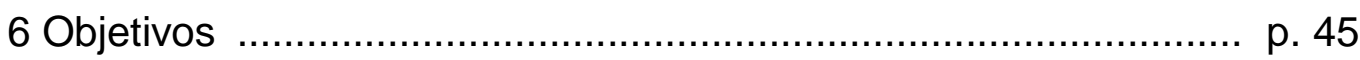

6.1 Objetivo geral ……........................................................ p. 45

6.2 Objetivos específicos …........................................................ p. 45

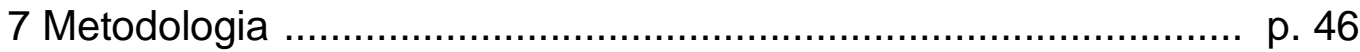

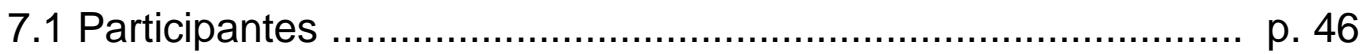

7.2 Procedimentos de coleta e análise dos dados ........................ p. 47

7.3 Cuidados éticos …........................................................... p. 48

8 Resultados e discussão …………………………................ p. 50

9 Considerações finais ........................................................... p.129

10 Referências ………....................................................... p.132

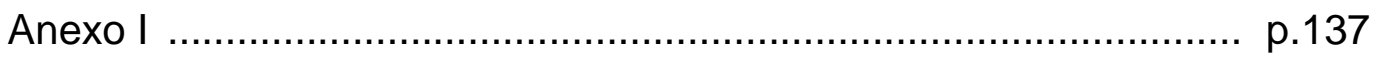

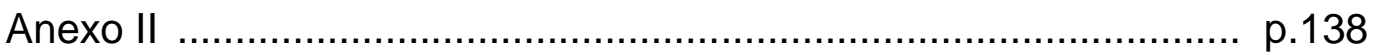


"Embora saibamos que depois de uma perda dessas o estado agudo do luto abrandará, sabemos também que continuaremos inconsoláveis e não encontraremos nunca um substituto. Não importa o que venha a preencher a lacuna, e, mesmo que esta seja totalmente preenchida, ainda assim alguma coisa permanecerá. E, na verdade, assim deve ser. É a única maneira de perpetuar aquele amor que não desejamos abandonar."

Sigmund Freud (em carta a Ludwig Binswanger) 


\section{1 Introdução}

A ideia deste trabalho surgiu a partir do meu encontro na clínica com mulheres que buscaram psicoterapia especializada em luto após a perda de seus bebês durante a gestação, no parto ou pouco tempo depois do nascimento de seus filhos. O foco da psicoterapia era o processo de luto e as repercussões trazidas pela perda na vida da paciente e de sua família. Entretanto, nesses primeiros momentos, aparecia também a ideia de planejamento de uma futura gravidez. A ambivalência de sentimentos entre o profundo desejo de uma nova gravidez e o medo de uma nova perda era bastante presente no discurso. Para muitas mulheres, a perda gestacional carrega a marca da falha do seu corpo e faz com que se pergunte se seu ventre é ainda um ambiente seguro para gerar um filho.

Muitos foram os questionamentos sobre qual seria o momento ideal para tentar engravidar novamente e a liberação médica não era, necessariamente, a autorização para o início das tentativas para todas. De que maneira o processo de luto influenciava nessa decisão? Em alguns momentos sentiam-se incapazes de enfrentar a gravidez e tudo o que o processo de gerar e gestar um bebê envolve, mas, em outros, acreditavam que o seu luto só seria "resolvido" com a chegada de um novo bebê.

Não há dúvidas que cada gravidez é única, mas foi possível verificar que a forma com que lidavam com o processo foi muito diferente do que antes de ter acontecido a perda: momento de contar sobre a gravidez, para quem contar, enxoval e roupas, chá de bebê. A alegria de estar grávida era visível, mas o medo de perder novamente dava o tom do percurso. Posso contar? Devo contar? Posso organizar as roupas e o quartinho? Não vou avisar quando for para a maternidade! E se eu perder novamente?

O bebê que chega após uma perda gestacional ou neonatal é chamado, por muitas famílias, de bebê arco-íris, sendo referido por elas que, assim como a luz do arco-íris aparece depois da escuridão de um céu chuvoso, um bebê arco-íris acontece depois da dor da perda. Acompanhei essas pacientes até o final da nova gestação e o tema e repercussões do luto estavam presentes até o momento do parto. Entretanto, chamou-me atenção que nenhuma dessas pacientes retornou à 
psicoterapia durante o primeiro ano de vida do bebê arco-íris. O luto tinha repercussões na vida daquela família ou havia sido resolvido coma chegada do bebê? O que estava acontecendo era uma inibição do processo? Que tipo de vínculo essas mães estavam construindo com seus bebês? Agora que estavam em seus braços era impossível se afastar deles? De que maneira a perda gestacional anterior interferiria na construção desse novo laço?

Esse estudo procurou identificar a forma como o vínculo mãe-bebê se constrói após uma perda gestacional e neonatal, buscando compreender como o luto poderia influenciar nessa construção.

A Teoria do Apego de John Bowlby (1907/1990), psiquiatra e psicanalista britânico, é um dos referenciais teóricos deste trabalho e visa compreender como se constroem os vínculos entre mãe e bebê. Bowlby $(2006,2002)$ refere que o apego será desenvolvido e definido pelo relacionamento afetivo profundo entre bebê/criança e cuidador. $\mathrm{O}$ impacto do vínculo entre cuidador primário e a criança é fundamental para a sobrevivência física e emocional e, por isso, essa relação inicial é tão importante para o desenvolvimento de todos os indivíduos.

O trabalho também abordou a construção do vínculo através das interações sociais que permitirão ao bebê desenvolver a capacidade de comunicar seu estado a seus parceiros sociais e relacioná-lo ao deles. Essas interações ocorrem a partir do nascimento e até mesmo antes dele, uma vez que a mãe é capaz de interpretar os movimentos do bebê ainda dentro da barriga (Seidl-de-Moura, 2009).

O processo de luto traz impactos nas mais diferentes esferas da vida do indivíduo: emocional, física, social, cognitiva, comportamental e espiritual. É um processo natural e esperado frente ao rompimento de um vínculo significativo, implicando na transformação e ressignificação da relação com aquilo que foi perdido (Bowlby, 2002,2004,2006; Franco, 2009; Parkes,1998,2009). Entretanto, o luto por uma perda gestacional ou neonatal carrega e especificidade de, muitas vezes, ser não-reconhecido (Doka, 1989) uma vez que se espera que a mulher possa logo engravidar novamente e "substituir" o filho perdido ou não se valida o vínculo com o bebê que não foi conhecido.

A questão que se coloca é de que maneira esse luto vivenciado e nãoreconhecido, ou que se espera que se resolva com a chegada de um novo bebê, pode influenciar no estabelecimento do vínculo com o bebê que foi concebido durante o processo de luto. 


\section{2 Construção de vínculo e interações iniciais}

Muito se tem discutido na atualidade sobre a importância das relações e interações sociais para o desenvolvimento humano, não só nas fases iniciais, mas ao longo de todo o processo de desenvolvimento. Importante ressaltar, entretanto, as marcas significativas que as primeiras interações deixam para toda a vida.

John Bowlby (1907/1990), médico e psicanalista inglês criador da Teoria do Apego, foi um dos primeiros autores a focar seus estudos na observação direta de crianças pequenas em diferentes situações. Iniciou os seus trabalhos de construção da Teoria do Apego na primeira metade do século XX, logo após ter saído da graduação. Suas observações acerca de meninos desajustados que viviam em um abrigo identificaram que havia ocorrido rompimentos importantes no relacionamento desses meninos com suas mães na primeira infância e que essas questões seriam precursoras de psicopatologias que aconteciam mais tarde. A partir desse primeiro estudo (Bowlby, 1944), constrói sua Teoria que reflete sobre a importância dos relacionamentos iniciais para o desenvolvimento imediato dos bebês e, não apenas, sobre o impacto das interações iniciais na vida das pessoas já adultas. Até aquele momento, a maioria dos estudos eram feitos a partir de relatos de adultos sobre suas experiências iniciais (Cassidy, 2008).

Em relação à motivação do bebê humano para se vincular a um outro, antes da construção da Teoria do Apego, a ligação entre o bebê e sua mãe (ou figura de cuidado principal) era explicada pela teoria do impulso secundário (Freud, 1916/1996) que propunha que a vinculação emergia pelo fato de a mãe alimentar seu bebê e esse prazer experimentado era o que criaria o vínculo (Bowlby, 2002). De acordo com Freud (1926/1996), a criança de colo quer sua mãe por saber que suas necessidades serão satisfeitas sem demora. Posteriormente, Freud (1940/1996) acrescenta, mais especificamente, que a origem do amor está na necessidade satisfeita do alimento. Portanto, o bebê se vincularia àquele que o alimentasse, assim como as relações afetivas na vida adulta teriam como motivação o desejo e necessidade de procriação.

A partir de observações sistemáticas de bebês humanos, Bowlby (2002) constata que estes também ficavam apegados a pessoas que não os alimentavam. 
Além disso, por não estar satisfeito com a explicação da teoria do impulso secundário, vai buscar ajuda com colegas de outras áreas do conhecimento, como a etologia, biologia evolucionista, teoria cognitiva e do controle dos sistemas e psicologia do desenvolvimento.

Segundo Bowlby (2002), esse laço tão forte resulta não apenas de um processo de aprendizagem associativa - mamar - prazer - vínculo, mas, também, de um desejo biologicamente baseado, de busca de proximidade, que surge através do processo de seleção natural. Quando falamos em relações de apego, a proximidade buscada, importante que seja ressaltado, não é com qualquer pessoa, mas, sim, busca-se proximidade de alguém considerado mais forte e mais sábio, capaz de fornecer conforto e segurança. Relações de apego devem ser capazes de fornecer conforto e segurança.

O trabalho de Bowlby (2006) aponta a importância do ambiente para o desenvolvimento psicológico, postulando, no início da construção de sua teoria, que o apego seria a propensão dos seres humanos a construírem vínculos significativos com outros específicos. Portanto, a vinculação do bebê com suas figuras significativas, sendo a primeira delas a mãe, tem um papel extremamente relevante no desenvolvimento social das crianças, assim como nos relacionamentos futuros que irá construir em sua trama de interações.

A formação, manutenção e rompimento de vínculo são consideradas as mais intensas experiências que o ser humano vive ao longo de seu ciclo vital (Bowlby, 2006). De acordo com Bowlby (2002), muitas são as evidências de que seres humanos de todas as idades parecem ser mais felizes e dotados de maior capacidade para desenvolver seus talentos quando se sentem seguros de que existe uma ou mais pessoas disponíveis caso surjam dificuldades ao longo da vida.

A importância dos contextos interacionais para a construção dos vínculos, além de também trazer para o foco a maneira como aspectos da mãe e do bebê influenciam na formação dos laços afetivos, são fios condutores da Teoria do Apego (Vicente, 2009). De acordo com Bowlby (2002), o padrão de interação que se desenvolve entre um bebê e sua mãe só pode ser compreendido como resultante das contribuições de ambos e, especialmente, da forma como cada um influencia o comportamento do outro.

As características iniciais de um bebê podem influenciar o modo como a mãe cuida dele, assim como as características da mãe também são capazes de 
influenciar na forma como seu bebê lhe responde. Bowlby (2002), acrescenta que a participação da mãe nessa interação é extremamente complexa, uma vez que advém não só de aspectos inatos e particulares, mas também de uma longa história de relações interpessoais em sua família de origem, assim como de práticas e valores da cultura em que está inserida.

Visto através a partir de um processo evolucionista, a busca pelo vínculo, a necessidade de estar ligado a alguém é uma adaptação básica para a sobrevivência. É através do mecanismo de apego que os bebês vão buscar extrair os cuidados essenciais de que necessitam para se manterem vivos. A construção do vínculo é, portanto, essencial para a sobrevivência do ser humano. Se não estivermos ligados a alguém, especialmente no início da vida, não será possível sobreviver.

Bowlby (2002) descreve o comportamento de apego como tendo duas características principais: seu objetivo é a manutenção da proximidade com um outro e a especificidade desse outro a quem o comportamento é dirigido. Nos bebês humanos, o comportamento de apego pode ser dirigido a outras pessoas, mas em relação à mãe, esses comportamentos acontecem mais cedo, mais fortemente e são mais sistemáticos.

Para alcançar essa proximidade, o bebê utiliza os comportamentos de apego, que têm como resultado previsível o aumento da proximidade entre o bebê e sua figura de apego (geralmente a mãe). Alguns comportamentos de apego servem para alertar a mãe sobre o interesse na interação (sorrir, vocalizar, por exemplo). Outros, como chorar, são comportamentos aversivos e fazem com que a mãe aja para terminar com ele. Em um momento um pouco mais adiante no desenvolvimento, se aproximar e seguir são movimentos que levam a criança na direção da mãe (Bowlby, 2002).

Muitos são os efeitos benéficos que resultam da proximidade da criança aos seus cuidadores, tais como, se alimentar, aprender sobre o ambiente e interação social. Cassidy (2008) pontua que, no ambiente da adaptação evolutiva, bebês que eram biologicamente predispostos a ficarem próximos de suas mães tinham menor chance de serem mortos por predadores, sendo esse o motivo de Bowlby (2002) ter identificado a proteção contra predadores como uma função biológica do comportamento de apego.

Por conta dessa função biológica do comportamento de apego, Bowlby (2002) considerava que os bebês têm a condição particular de procurar por seus pais 
em momentos de ameaça e estresse. A partir dessa leitura, o apego é, então, considerado uma característica normal e saudável dos humanos ao longo do ciclo vital.

Os comportamentos de apego são organizados em sistemas de comportamento de apego, agrupados em um conjunto de comportamentos específicos que levam a resultados específicos. A meta-fixada desses comportamentos é a proximidade da mãe. Os comportamentos escolhidos vão de acordo com o momento específico e particular, uma vez que o bebê escolhe, dentro de seu repertório, o que achou ser mais útil naquele momento para atingir a meta de proximidade. Ao longo do desenvolvimento, a criança é capaz de ter acesso a uma maior gama de formas de alcançar a proximidade e com isso, vai aprendendo quais são as mais eficazes para cada circunstância. A meta do comportamento de apego não é um objeto (a mãe), mas um estado de segurança que a manutenção de certa proximidade da mãe proporciona. Quando a separação entre mãe e bebê se torna grande demais, em tempo ou em distância, o sistema de apego é ativado e quando a proximidade suficiente é alcançada, ele é desligado (Bowlby, 2002).

A proximidade necessária não é sempre a mesma e varia de acordo com as circunstâncias. Condições de perigo ou estresse parecem ativar o sistema de apego. Tais condições podem estar relacionadas a um estado da própria criança (doença, cansaço, dor) ou ao ambiente (presença de estímulos ameaçadores). Também é muito importante a maneira ou motivos pelos quais a mãe se distancia dessa bebê (rejeição, abandono, morte) tendo influência na ativação do sistema de apego. O comportamento de apego é cessado na presença de um estímulo que é capaz de o colocar a termo. As circunstâncias que envolvem o desligamento do comportamento de apego estão relacionadas à forma pela qual este foi ativado. Se o sistema de apego foi intensamente ativado, o contato físico com a mãe pode ser necessário para acalmar. Se foi moderadamente ativado, a presença da mãe pode ser suficiente. Em ambos os casos, o bebê utiliza a mãe como porto seguro de que necessita em momentos de estresse ou ameaça (Cassidy, 2008).

De acordo com Vicente (2009), o desenvolvimento do apego acontece através das interações realizadas pelo bebê e da maneira encontrada por ele para lidar com os conteúdos emocionais e afetivos gerados por essas interações.

Bowlby (2006) descreve quatro fases para a construção do vínculo de apego. 
a) Nas primeiras semanas, é vivenciado o período "pré-apego" no qual são manifestados os primeiros comportamentos que aproximam o bebê de sua figura principal de cuidado, o que indica a predisposição para a interação social e consequente vinculação. Aqui, apesar de ser evidenciada uma figura de preferência, o bebê não demonstra desconforto em sua ausência, se deixado sob cuidados adequados e contingentes de outras pessoas.

b) Por volta de dois meses e meio, há mudanças qualitativas no mundo interno do bebê e na sua condição física, o que facilita as trocas emocionais. Esse é o chamado período de "estabelecimento do apego" em que passa a discriminar pessoas conhecidas de desconhecidas e começa a sorrir socialmente, sendo aqui iniciados os jogos faciais. É capaz de demonstrar afeto positivo para a mãe através de novas habilidades conquistadas e esta responde às ações do bebê. Em torno dos seis meses de idade, inicia-se o período de "apego propriamente dito", quando o bebê já é capaz de buscar e manter a proximidade através de locomoção e de sinais direcionados a esse outro específico e preferido.

c) Aos nove meses há um aumento da busca de conhecimento do mundo e é também o momento em que surgem os comportamentos de ansiedade de separação e ansiedade em relação a estranhos que podem ser compreendidos como facilitadores da manutenção do vínculo mãe-bebê, uma vez que a separação da figura principal de apego é sentida como perigosa e ameaçadora. Nesta fase do desenvolvimento do apego são explicitados os comportamentos de Base Segura. É a partir da confiança nessa pessoa específica, considerada mais forte e mais sábia, que o indivíduo se sentirá seguro e capaz de explorar e conhecer o mundo. Primeiro em pequenas jornadas que vão alargando a partir da experiência de se sentir capaz e seguro de ter para onde voltar.

d) O quarto período de desenvolvimento do apego é descrito como "relacionamento recíproco", uma vez que nesse momento o bebê compreende melhor os comportamentos da mãe e é capaz de se ajustar a eles assim como também pode modificá-los.

Algumas condições contribuem para o desenvolvimento do apego a uma figura específica, tais como, a sensibilidade dessa figura para responder aos sinais do bebê e a quantidade e natureza das interações entre os componentes dessa dupla. 
Ao longo do desenvolvimento, é possível perceber que a mãe passa a esperar e perceber, de modo típico, os comportamentos do bebê, assim como a criança também passa a aguardar e receber, de modo típico, as interações com a mãe (Bowlby, 2002). Nota-se, portanto, que o comportamento de um é capaz de modelar o do outro.

De acordo com o Bowlby (2002), o padrão de comportamento de apego que o bebê vai desenvolvendo ao longo da vida está relacionado às suas inclinações iniciais, mas também à forma como a mãe responde ao contato. Da mesma maneira, a mãe também é afetada pela forma como o bebê interage com ela, sendo difícil estabelecer se o comportamento do outro é resultado de uma inclinação inicial ou se é resultado da influência do outro.

Ao explicar a relação entre o comportamento de apego e o comportamento exploratório, Bowlby (1988) aponta que uma regra da relação de cuidado é que o mais frágil e menos experiente busca a proteção de um outro considerado mais forte e mais sábio. Aquele que está no papel de ser cuidado mantém o cuidador ao seu alcance, e o grau de proximidade e acessibilidade varia conforme as circunstâncias: daí advém o conceito de comportamento de apego. Um outro componente importante da natureza humana é a necessidade de buscar a exploração do ambiente, comportamento antagônico ao comportamento de apego. $\mathrm{O}$ autor afirma que, quando um indivíduo de qualquer idade se sente seguro ele é capaz de explorar o ambiente, mesmo longe de sua figura de apego. Por outro lado, quando se sente ameaçado, ansioso ou cansado, busca proximidade e proteção. Esse é o padrão típico de interação a partir de uma base segura (Bowlby, 1988). Quando confia que os pais estarão acessíveis e serão responsivos quando precisar, a criança é capaz de sair para exploração. Entretanto, é necessário também que os pais promovam a capacidade exploratória da criança.

São inúmeras as formas e variações na interação mãe e bebê, mas pesquisadores acreditam que seja possível encontrar algo de universal na maneira como as crianças se organizam em relação às suas figuras significativas (Vicente, 2009). A partir dessa premissa, foi desenvolvido por Mary Ainsworth (2015), o procedimento da Situação Estranha, único procedimento laboratorial validado para avaliar apego em crianças pequenas, no qual busca-se testar empiricamente o padrão de segurança do vínculo da criança com a mãe. A hipótese é de que mães e bebês reproduzem na Situação Estranha os seus comportamentos cotidianos. 
O procedimento da Situação Estranha é realizado com bebês de 12 meses em uma série de episódios de três minutos, com duração total de vinte minutos, nos quais a criança é observada em uma sala pequena e confortável, com um número significativo de brinquedos (que não lhe são familiares), primeiro na companhia de sua mãe, depois sem ela e, finalmente após a sua volta.

O bebê que consegue fazer suas explorações com razoável liberdade em uma situação estranha - usando a mãe como base segura - que não se amedronta com a chegada de uma pessoa estranha, que demostra saber do paradeiro da mãe, mesmo na sua ausência, e que acolhe calorosamente quando ela retorna é identificado como seguramente apegado, de acordo com a classificação de Ainsworth (2015). São considerados seguramente apegados, mesmo que se mostrem aflitos temporariamente com a ausência da mãe ou enfrentem com tranquilidade breves períodos distantes da mãe.

De acordo com a autora, em um polo oposto, encontram-se os bebês inseguramente apegados e que não são capazes de fazer qualquer exploração mesmo quando a mãe está presente e/ou se mostram muito aflitos na presença de um estranho e/ou se desorganizam significativamente quando a mãe se ausenta e demoram para se sentirem tranquilos mesmo quando ela retorna. São também considerados inseguros e adotam estratégias de evitação, os bebês que não se afetam em absoluto na ausência da mãe, assim como também demonstram um aparente desinteresse em seu retorno.

No Teste da Situação Estranha foram identificados três padrões de apego, denominados por Ainsworth (2015) como:

Padrão A - Ansiosamente apegados à mãe e esquivos - constituem aproximadamente $20 \%$ das amostras e evitam a reunião, especialmente após o segundo momento de ausência.

Padrão B - Seguramente apegados à mãe - constituem a maioria na maior parte das amostras e tem como características serem ativos nas brincadeiras, buscam contato quando se sentem aflitos e, logo se tranquilizam após serem confortados pela mãe, retornando à brincadeira.

Padrão C - Ansiosamente apegados à mãe e resistentes - constituem aproximadamente $10 \%$ das amostras e oscilam entre a busca por proximidade e contato com a mãe e a resistência ao contato e à interação. 
O processo de vinculação é descrito por Bowlby (2002) como sendo realizado na interação, uma vez que, o sistema de comportamento de apego possibilita que o indivíduo responda de maneira flexível às mudanças no ambiente (inclui-se aqui a mãe como ambiente) enquanto procura atingir a meta.

Considera-se como característica fundamental das interações iniciais mãebebê, a capacidade de estabelecer uma harmonia ou adaptação mútua entre os ritmos de comportamento além da regulação da atenção conjunta. Pode-se perceber que as diferenças na forma de cuidado refletem em diferenças na forma de interação.

O bebê humano é dependente do cuidado do outro para sobreviver e, também, tem como característica essencial sua predisposição para trocas. Segundo Keller (2002), os bebês são equipados desde seu nascimento, ou até mesmo antes dele, de predisposições específicas que apoiam o seu desenvolvimento e crescimento. Uma dessas predisposições é que os bebês são capazes de "atrair" seus cuidadores, fazendo com que voltem sua atenção para eles. São dotados de características como Kindchenschema (Lorenz, 1943). O esquema corporal próprio dos bebês, como cabeça grande, rosto redondo e olhos grandes, bochechas fofas, boca e nariz pequenos, extremidades pequenas e grossas, que são percebidas como graciosas pelo outro, servem para motivar um comportamento de cuidar por parte daqueles que tem como função garantir a sobrevivência dos pequenos (Glocker, M. L., Langleben, D.D., Ruparel, K., Loughead, J.W. \& Sachser, N., 2009).

Ao manter essas características por algum tempo, os bebês são capazes de estimular no outro, mesmo que não seja de sua família, a proteção e consequente sobrevivência por mais tempo. Ademais, Keller (2002) pontua que os bebês humanos, por conta da sua natureza social, preferem os rostos humanos em relação a qualquer outro dispositivo e esperam que essas faces sejam responsivas ao seu contato. O que indica a predisposição de necessidade de interação desde as fases iniciais do desenvolvimento. Os bebês são sensíveis à estimulação e experienciam alívio quando recebem conforto, mas não são apenas passivos em relação a esse contato, pois também são capazes de afetar o outro nessa interação, já que participam ativamente da relação, construindo sua matriz social precoce (Keller, 2002).

Para Seidl-de-Moura (2009), a interação social tem como uma de suas consequências o desenvolvimento da capacidade de um indivíduo se colocar no 
lugar de outro, além de perceber os outros como seres intencionais. Acrescenta que o início das interações acontece mesmo antes do nascimento, no desenvolvimento pré-natal do bebê, que ao fazer movimentos dentro do útero da mãe já tem suas ações interpretadas por ela. Em contrapartida, o bebê também parece ser capaz de responder a alterações emocionais da mãe. Regulam-se assim, mãe e bebê, mesmo antes do nascimento.

Os bebês humanos nascem, de certa forma, prematuros, o que requer um maior investimento de cuidados. Portanto, faz-se necessário um ambiente de cuidados que possa compensar essas necessidades, assim como ajudar o bebê a desenvolver um repertório de comportamento adequado à sua cultura para que possa ensejar no outro uma atitude de cuidado. Assim como o bebê tem seu repertório de comportamentos para acionar no outro um comportamento de cuidado, os cuidadores também são dotados de predisposições de cuidado para interagir com seus bebês (Keller, 2002).

De acordo com Keller (2002), os sistemas parentais têm sua base em uma concepção etológica de sistemas de comportamento, uma vez que são organizados para atingir uma determinada meta e regulam a interação intencionalmente ou intuitivamente. Não se pode deixar de levar em conta o fato de que os cuidados parentais estão inseridos dentro de uma cultura que identifica o que é considerado bom ou ruim para os bebês dentro daquele contexto.

De uma maneira geral, a parentalidade compreende a motivação para os cuidados com o bebê através de uma atenção específica, consolo e conforto em momentos de maior desgaste, assim como responder adequadamente aos sinais de comunicação, além de estimular o crescimento e o desenvolvimento. A parentalidade está inserida em um contexto de interação e pode ser exercida por qualquer pessoa que tem como função prover cuidado. É organizada em conjuntos de comportamentos, definidos por Keller (2002) como: "cuidados primários", "contato corporal", "estimulação corporal", "estimulação por objeto" e "trocas face-a-face". Os processos psicológicos que são iniciados, a partir de cada um desses sistemas parentais, são modulados pelos cuidadores a partir de algumas características que promovem seu estilo de interação e o que buscam através desse contato.

a) Cuidados primários - Caracterizam-se pelo provimento de cuidados primários aos bebês, tais como comida, abrigo e higiene e certamente 
representam a forma mais antiga de cuidados parentais. A forma como esse sistema vai funcionar pode variar, na medida em que, sob determinadas circunstâncias, pode não haver, por exemplo, a possiblidade de alimentar o bebê adequadamente. Em situações como essa, o cuidado é oferecido, majoritariamente, através da proteção e abrigo. A função psicológica dessa forma de cuidado é reduzir o estresse, mais do que dividir momentos agradáveis com o bebê. Ao sentir que suas necessidades primárias são atendidas e seu nível de estresse é diminuído, o bebê expressa segurança e confiança na proteção daquele que lhe provê cuidados.

b) Contato corporal - $\mathrm{O}$ contato físico e o carregar extensivo são considerados um sistema parental. Em muitas culturas, os bebês são carregados junto ao corpo de suas mães durante um período significativo do dia. Carregar o bebê junto ao corpo é uma estratégia de proteção frente aos perigos e ameaças a que podem ser expostos, como fogo e animais venenosos em alguns ambientes. Pode parecer ser uma estratégia primitiva, visto que é uma estratégia de cuidado bastante utilizada pelos macacos. Porém, constata-se que, na espécie humana, os cuidadores muitas vezes pegam seus filhos no colo quando sentem que o ambiente é ameaçador, assim como os bebês também procuram o contato corporal quando se sentem em perigo ou inseguros. A função psicológica do contato corporal consiste na experiência do calor emocional. A proximidade física da mãe ou outro significativo é capaz de estimular o vínculo emocional que estabelece o desenvolvimento de sentimentos de estar relacionado a alguém e, também, de pertencimento.

c) Estimulação corporal - Esse sistema também é baseado na comunicação que é feita através do corpo, mas acontece em uma atividade diádica exclusiva. Os cuidadores estimulam os bebês promovendo experiências motoras que são desafiadoras através do toque e do movimento e, ao observar suas reações, modulam seus comportamentos. Essa forma de cuidado é uma reposta individual do adulto àquela criança específica, sendo, portanto, um sistema de cuidado que acontece somente na interação. Esse tipo de interação está muito ligado ao desenvolvimento motor da criança. A função psicológica da estimulação corporal parece ser uma maior e melhor 
percepção do próprio corpo, que faz com que este seja percebido como agente no ambiente e não apenas um corpo passivo.

d) Estimulação por objeto - A estimulação por objeto acontece sempre que o bebê é ligado a um mundo de objetos, como também ao ambiente de uma forma geral. A estimulação por objeto está muito relacionada a atividades exploratórias e tem como função psicológica nutrir o sistema cognitivo, além de desengajar o bebê da dependência de relacionamentos sociais.

e) Trocas face-a-face - As trocas face-a-face são essencialmente caracterizadas como contato ocular mútuo e frequente uso da linguagem. Essa forma de investimento parental consiste, principalmente, em uma dedicação e devoção exclusiva de tempo e atenção em trocas diádicas. As trocas face-a-face acontecem através de respostas que são dadas prontamente pelo cuidador aos sinais de comunicação do bebê, o que permite que este se perceba como causa da ação parental. As trocas face-aface são capazes de proporcionar ao bebê o sentimento de ser único e especial para aquele cuidador, além de também ser uma forma de compartilhar emoções positivas e se sentir relacionado a alguém, sendo essas as funções psicológicas desse sistema parental.

O envelope narrativo perpassa todos esses sistemas e pode ser considerado como um sexto sistema parental, uma vez que a linguagem e a maneira exclusiva de se comunicar com o bebê estão presentes em todas as formas de interação.

De acordo com Seidl-de-Moura (2009), as interações constituem o palco do desenvolvimento humano, sendo necessários engajamento e sincronia mútuos. A dimensão emocional da interação influencia as percepções, comportamentos e a possibilidade de compreendermos nós mesmos, nossos parceiros e o mundo. Portanto, não há como se pensar na formação do laço afetivo sem levar em conta a dupla que se interinfluencia durante todo o processo.

É importante marcar o aspecto bidirecional das interações, já que, para que estas ocorram é necessário que as ações sejam recíprocas - um que responde ao outro e vice-versa. As interações permitem ao bebê desenvolver capacidades de, a partir de experiências emocionais, comunicar seu estado aos parceiros e relacionálos a ele. Adulto e bebê devem ser considerados parceiros, sendo aqui considerado o papel ativo do bebê nas trocas com o adulto. Considera-se, portanto, um modelo 
de mão-dupla de interação e desenvolvimento, devendo ser consideradas a reciprocidade, adaptação mútua e as características individuais (Seidl-de-Moura, 2009).

As questões acerca da construção de vínculo e das interações sociais seguem, ainda hoje, muito focadas na mãe e pouco se tem discutido sobre o papel do pai nesse cenário inicial. Entretanto, autores da teoria do desenvolvimento evolucionista têm abordado a importância da convivência e não só do parentesco como propiciador de vinculações afetuosas e significativas entre os pais e seus bebês (Bussab, 2000).

Nunes, Fernandes e Vieira (2007) afirmam que há um crescimento do reconhecimento da participação dos pais como muito significativa nos cuidados parentais, possibilitando que o desenvolvimento do bebê aconteça em uma tríade interativa e não só na díade mãe-bebê. De acordo com os autores, há evidências de que a ausência ou deficiência do pai pode trazer repercussões negativas não só para o bebê, mas também para a mãe, tanto na gravidez quanto na maternagem. Considera-se, portanto, de fundamental importância, a presença e participação do pai no processo de vinculação com o bebê, assim como a presença suportiva junto à mãe também é um elemento facilitador dos cuidados e interações iniciais.

Ao se considerar a construção de vínculo nas etapas iniciais da vida como fundamental e estruturante para o ser humano e a mãe como uma das principais referências de cuidado, torna-se fundamental compreender as diferentes abordagens sobre o processo de luto para posteriormente refletir sobre o impacto de uma perda significativa nas interações com o bebê. Ademais, a ideia de que é possível ou necessário inibir ou adiar o processo de luto para que este não interfira no relacionamento com o bebê pode também repercutir no novo vínculo. 


\section{3 \\ O processo de luto}

O processo de luto é uma reação esperada e natural frente ao rompimento de um vínculo significativo. Franco (2010a) descreve o luto a partir de uma compreensão dinâmica e particular, como um processo de construção de significados que possibilita revisões na identidade, nas relações sociais e no sistema de crenças. De acordo com Barbosa (2016), trata-se de uma resposta adaptativa a uma experiência de perda que desencadeia diversas transformações na vida de uma pessoa.

Freud (1917/1996) tornou-se uma das grandes referências para o estudo do luto, uma vez que apresentou, pela primeira vez, uma análise sistemática do luto. Distinguiu minuciosamente luto e melancolia, afirmando que o luto não seria algo patológico e, portanto, não deveria receber qualquer tipo de intervenção, já que naturalmente se resolveria. $\mathrm{O}$ autor descreveu o luto como uma resposta mental em que a energia dirigida ao objeto perdido é progressivamente retirada e volta-se para o próprio sujeito enlutado e, ao fim de algum tempo, o ego volta a ficar livre para retornar o investimento no mundo externo. Durante esse período, o enlutado sentiria, especialmente, o mundo exterior mais vazio. O trabalho de luto estaria finalizado quando o sujeito desvinculasse sua energia do objeto perdido e voltasse a investir no mundo externo.

Franco (2010) pontua que, antes mesmo de Freud, o luto já estivera em destaque. Em 1621, Robert Burton publicou A anatomia da melancolia e afirmava que o pesar gerado por uma perda era tanto sintoma quanto causa da melancolia. Benjamin Rush (1746/1813), médico norte-americano, foi um dos primeiros a mencionar a "síndrome do coração partido", e descrevia a dissecção de cadáveres de pessoas falecidas por luto. Segundo Rush (1935), pessoas que tinham como causa da morte uma perda significativa apresentavam inflamação no coração e rompimento de aurículas e ventrículos. Além disso, ele também recomendava que os enlutados se afastassem do quarto do falecido e receitava ópio em doses significativas para estes.

A partir da publicação de Lindemann (1944), os pesquisadores começam a desenvolver estudos empíricos sobre o luto e suas consequências. Os sintomas 
relacionados ao luto descritos no estudo deste autor seguem sendo, ainda hoje, significativos nas avaliações de enlutados.

John Bowlby tem um papel fundamental nos estudos e pesquisas sobre o luto, pois, a partir da experiência com as crianças separadas de seus pais durante a guerra, elabora a Teoria do Apego. Ele postula o luto como consequência do rompimento de um vínculo significativo. A partir da observação das reações das crianças a essa separação, descreve o processo em quatro fases (Bowlby, 2004):

a. Entorpecimento: normalmente ocorre a partir da notícia da morte e pode durar de poucas horas até alguns dias. É caracterizada por choque, torpor e descrença. A pessoa parece estar desconectada do mundo, podendo haver crises de raiva ou intenso desespero. $\mathrm{O}$ entorpecimento tem uma função protetora, podendo ser compreendido como uma defesa, na medida que faz com que a pessoa disponha de tempo para assimilar o impacto da perda. Essa fase se encerra no momento em que a pessoa é capaz de aceitar, ao menos cognitivamente, que a pessoa se foi.

b. Anseio e procura: após a compreensão racional de que a perda aconteceu, o caminho para a aceitação emocional é longo e doloroso. Nesta fase, há intenso sofrimento psicológico, fortes emoções e até mesmo agitação física. $\mathrm{O}$ enlutado parece procurar a pessoa que se foi, indo a lugares onde antes podia encontrá-la, sendo comum confundi-la com outras pessoas na rua, o que gera frustração quando percebe o engano. É comum a sensação de presença, uma vez que o enlutado "vê", "escuta", sonha ou simplesmente acredita que a pessoa que morreu está ali. Pode ocorrer intensa preocupação com lembranças, pensamentos e objetos do morto. A sensação de presença faz com que, muitas vezes, pessoas próximas, e até mesmo o enlutado, percebam essa reação como loucura. De acordo com o autor, as manifestações transitórias que se parecem com "visões" ou "alucinações" são consideradas pertinentes e até mesmo esperadas no cenário do luto.

c. Desorganização e desespero: no momento em que o enlutado se dá conta que todo o seu comportamento de busca é em vão, recai sobre ele uma onda de apatia, desespero e depressão. É possível encontrar aqui uma necessidade de chorar alto, o que permite o compartilhamento do sentimento e faz com que as pessoas possam se aproximar do enlutado para oferecer 
suporte. É comum que, nesse período, o enlutado diga que sua vida perdeu o sentido e que não sente qualquer prazer em suas atividades. Essa parece ser uma das fases mais dolorosas do processo. São comuns a dificuldade de concentração e a sensação de estar alheio a tudo que não diz respeito à sua dor. Os sintomas somáticos, tais como, distúrbios no sono e na alimentação, persistem e, frequentemente, tornam-se até mesmo mais intensos. Risco de suicídio aumentado durante essa fase.

d. Reorganização: quando chega a essa fase, o enlutado começa a ter vontade, gradativamente, de voltar a se interessar pela vida e pelas pessoas que estão ao seu redor. Pode acontecer o resgate de relacionamentos antigos e até mesmo a construção de novos laços. Enlutado parece ter de volta a sua independência e autonomia, advindas da compreensão e aceitação de que a perda é irrevogável. Importante destacar, entretanto, que mesmo após a fase de reorganização, o enlutado pode ter o retorno de alguns sintomas, especialmente em datas significativas relacionadas ao enlutado, ao falecido ou ao falecimento.

Colin Murray Parkes (2009), psiquiatra britânico, complementa Bowlby e afirma que, assim como as crianças pequenas separadas de suas mães nos ensinam sobre o modo como se relacionam com ela e como percebem o mundo, os adultos que perdem uma pessoa amada também se comportam de uma maneira que nos ensina sobre seu relacionamento com ela e, também, com os outros. O primeiro fruto da colaboração entre esses autores foi um artigo (Bowlby \& Parkes, 1970) em que foram identificadas as similaridades entre a resposta de adultos à perda de um companheiro e a resposta de crianças pequenas à separação de suas mães.

Parkes (2009) destaca o fato de ter se juntado a Bowlby na compreensão do luto dividido em fases. Entretanto, ele faz uma crítica a esse entendimento, pois apesar de sugerir uma maneira de explicar o luto, apresenta a explicação de uma forma muito mais simples do que é o processo na realidade. Afirma que, com o passar do tempo, as fases do luto passaram a ser utilizadas como prescrição para o luto normal.

O livro de Parkes (1998) é um marco importante nos estudos sobre o luto, uma vez que consolidou muitas pesquisas que haviam sido realizadas até aquele momento e até hoje segue sendo reeditado em intervalos regulares no mundo todo. 
Há, ainda hoje, a compreensão de que o luto envolve apenas uma resposta emocional frente a uma perda. O luto envolve muito mais do que uma reação de pesar e nos coloca em contato com a sensação de ameaça à segurança e mudanças significativas na vida e na família. Outro ponto importante a ser ressaltado são os componentes essenciais do luto: a experiência de perda e o anseio intenso pelo objeto perdido (Parkes, 2009).

Segundo o autor, há evidências de que a perda de um vínculo significativo traz consequências importantes para a saúde, incluindo até mesmo o risco de morte. Além disso e, principalmente, pode acarretar perigos psicológicos importantes, uma vez que há grande intensidade das emoções evocadas pelo amor e pela perda. Parkes (2009) afirma que o luto por morte é uma das experiências mais graves e potencialmente danosas da vida de uma pessoa. Essa afirmação torna-se ainda mais contundente se pensarmos que a experiência de luto será vivenciada por quase todos nós em algum momento da vida.

Cabe aqui destacar que o trabalho de pesquisa e intervenção com enlutados de Parkes (1971) levou à construção de sua teoria da transição psicossocial. O conceito de mundo presumido é fundamental para o entendimento deste modelo de compreensão do luto. Mundo presumido é o aspecto do mundo interno que é tido como verdadeiro e garantido, e estão contidas nesse mundo as concepções sobre tudo que há de mais estruturante em nossas vidas: concepção sobre si mesmo, estratégias para lidar com o perigo e com o desconhecido, além de inúmeras cognições das quais dependem o sentido da vida (Parkes, 2009). Essas concepções são construídas umas sobre as outras e a maioria das modificações realizadas não desestabilizam a estrutura, a base. As mudanças significativas da vida fazem com que o mundo, que até então era garantido, precise ser modificado. As mudanças vividas a partir da perda desafiam o mundo presumido e provocam uma crise que desencadeia reações de inquietação, tensão, ansiedade e indecisão, com uma consequente dificuldade e até mesmo impossibilidade de transitar nesse mundo que passa a ser imprevisível e desconhecido. Na concepção de Parkes (2009), o processo de luto deve ser compreendido como um trabalho de transição. Após uma perda significativa não é mais possível viver como antes, sendo, então, necessária uma transição psicossocial para adaptação ao novo mundo e ao novo eu.

Muito se tem pesquisado a respeito de quais fatores teriam papel decisivo nos caminhos do luto e o que deveria ser avaliado para decidir se o processo terá 
um bom ou mau resultado. Parkes (2009) destaca como fundamental a avaliação dos seguintes fatores como possíveis preditores de risco: a vulnerabilidade pessoal do enlutado; a relação com a pessoa falecida; os eventos e circunstâncias que levaram à morte, bem como a morte em si e o apoio social e outras circunstâncias após a morte.

A culpa é uma resposta comum frente a uma situação de luto. As pessoas costumam pensar no que poderiam ter feito diferente quando têm uma perda significativa, o que pode fazer com que se sintam culpadas. Stroebe et al (2014) identificaram associação positiva entre autoculpabilização e sintomas de luto: altos níveis de autoculpabilização foram associadas com altos níveis iniciais de luto e uma diminuição mais lenta do luto com o passar do tempo. Esse padrão é consistente com a hipótese de que a autoculpabilização tem um papel importante na determinação do curso do luto.

Para se compreender o significado de uma perda é necessário que se compreenda a história do enlutado, os detalhes de sua história pessoal e como foi construída sua identidade. A perda de alguém significativo tem um lugar único na história daquela pessoa, é algo subjetivo e particular, não sendo possível ser encaixada em um padrão pré-estabelecido (Attig, 2011). A morte transforma profundamente a experiência que se tem da vida, de tal maneira que é importante apreender as diferentes maneiras através das quais a morte modifica o fluxo da vida de cada um e como o enlutado encara os desafios para seguir em frente. Attig (2011) aponta uma questão importante do processo de luto: quando alguém se enluta, um evento ou uma série de eventos, sobre os quais não se tem controle, aconteceram e muito disso (ou tudo isso) não pode ser desfeito - não há a possibilidade de que o outro volte a viver, isto é, a vida nunca mais será como antes. De acordo com o autor, alguns se colocam de maneira passiva frente ao luto, por acharem que nada podem fazer, ao passo que parece ser necessário enfrentar o luto, lidar com ele, ao invés de sucumbir a ele. O luto é um processo ativo, uma vez que o enlutado pode escolher, em alguma esfera, a forma como irá lidar com sua perda. Faz-se necessário organizar uma nova vida e uma nova forma de estar no mundo, pois há sempre novos desafios a serem endereçados e novas opções que se abrem. Ao escolher um caminho para o luto, abre-se a oportunidade de descobrir novos caminhos e possibilidades. Lidar com a perda implica dar uma resposta ativa ao que mudou a direção da vida. 
Worden (2013) estabelece um modelo que compreende o luto através de tarefas e o considera mais útil para a clínica. De acordo com o autor, pensar o luto, a partir de fases, implica uma certa passividade, uma vez que o enlutado pode percebê-las como algo que simplesmente precisa atravessar. Já um modelo que propõe tarefas, posiciona o enlutado de uma maneira mais ativa, uma vez que ele precisa agir, o que pode lhe dar a esperança de que tem algo que possa fazer ativamente para se adaptar à perda. $\mathrm{O}$ autor ainda afirma que é essencial que a pessoa enlutada se debruce sobre as tarefas a fim de que possa se adaptar à perda e cada um fará essa adaptação de maneira singular. Apesar de as tarefas não necessitarem acontecer em uma ordem específica, Worden (2013) sugere um ordenamento em suas definições, uma vez que não é possível realizar algumas das tarefas sem que outras tenham sido ultrapassadas.

Tarefa I - Aceitar a realidade da perda: a primeira tarefa do luto é encarar a realidade que a pessoa está morta e não vai mais voltar, sendo parte da aceitação acreditar que o reencontro é impossível (pelo menos nessa vida). Em oposição à aceitação está a descrença, por meio de uma espécie de negação, que acontece quando as pessoas se recusam a aceitar que a morte é real e ficam paralisadas nessa primeira tarefa do luto. Uma maneira de se proteger da realidade da perda é perceber a perda como algo insignificante. Outras pessoas impedem a conclusão dessa tarefa ao negar que a morte é irreversível. Atingir a aceitação da realidade da perda leva tempo, pois implica não só a aceitação cognitiva, mas também emocional, que é, muitas vezes, mais difícil e complexa. Os rituais de luto podem facilitar a conclusão dessa tarefam, uma vez que homenageiam a vida vivida e ratificam que a morte aconteceu.

Tarefa II - Processar a dor do luto: é necessário que a pessoa passe pelo sofrimento do luto para que este seja resolvido, pois, ao suprimir a dor ou evitá-la o processo de luto é prolongado no tempo. Worden (2013) afirma que, mesmo sendo o luto vivenciado por cada um de formas e intensidades diferentes, parece ser impossível perder alguém significativo sem sofrer em algum nível. A ausência desta tarefa de processamento da dor tem como consequência uma não sentir e, em alguns casos, as pessoas encurtam essa tarefa suprimindo os sentimentos e negando a dor que acompanha o rompimento de um vínculo significativo. Por vezes, o processo é bloqueado, 
e evita-se, a qualquer custo, pensamentos dolorosos. O autor ressalta que o sofrimento do luto não está ligado apenas à tristeza e que existem outras emoções ligadas à perda, tais como raiva, culpa, solidão, entre outras, que também precisam ser processadas.

Tarefa III - Ajustar-se a um mundo sem a pessoa morta: diferentes ajustes são necessários no enfrentamento à perda de uma pessoa significativa. São necessários ajustes externos, uma vez que a perda afeta o contexto habitual da vida; ajustes internos, pois a morte afeta o senso de si mesmo da pessoa; assim como também são necessários ajustes relacionados às crenças, valores $\mathrm{e}$ suposições da pessoa sobre $\mathrm{o}$ mundo. $\mathrm{A}$ impossibilidade de realizar essa tarefa resulta em um fracasso na adaptação à perda, uma vez que as pessoas não se mostram capazes de desenvolver habilidades necessárias para esse enfrentamento e/ou se afastam do mundo para não enfrentar as exigências do ambiente. Entretanto, a maior parte das pessoas parece ser capaz de assumir novos papeis, desenvolver novas habilidades e ter uma nova percepção sobre si mesmas e sobre o mundo.

Tarefa IV - Encontrar uma conexão duradoura com a pessoa morta em meio ao início de uma nova vida: a partir da compreensão de que as pessoas não se separam de quem morreu, mas encontram uma nova forma de relacionamento, torna-se fundamental encontrar um local apropriado para o morto na vida emocional do enlutado. Para muitas pessoas, é extremamente difícil concluir essa tarefa, ficam paralisadas e, mais tarde, percebem que a vida ficou estancada no momento em que a perda aconteceu.

Um modelo alternativo de luto é proposto por Neimeyer (1999), que tem como argumento principal a reconstrução de significado em resposta à perda como central no processo de luto. Essa forma de olhar para o processo de luto é advinda da Psicologia Construtivista que compreende o ser humano como um grande construtor de significados, que tece narrativas a respeito dos eventos significativos de sua vida. As estruturas de significados que são construídas ao longo da vida estão ancoradas não apenas na realidade objetiva, mas, sobretudo nas relações com outros significativos e na cultura em o indivíduo está inserido.

Neimeyer, Klass e Dennis (2014) referem que, apesar de o luto ser um processo universal e biológico, tanto a história da morte em si quanto a mudança no relacionamento com aquilo que perdemos, são narradas pessoalmente, divididas 
socialmente e expressadas de acordo ou em contradição com as normas da comunidade. A forma como esse rompimento é vivenciado é totalmente pessoal e terá uma narrativa e um significado próprios para cada pessoa, de acordo com as circunstâncias e momento de vida, assim como o lugar que o vínculo rompido passa a ocupar na continuidade da vida do enlutado.

A ideia de que as pessoas não se desligam da pessoa que morreu, não retiram todo o investimento desse relacionamento, mas desenvolvem um vínculo continuado com a pessoa falecida foi cunhada por Klass, Silverman e Nickman (1996). Durante muitos anos, parece ter sido um consenso entre psicólogos e psiquiatras que o luto bem-sucedido aconteceria quando o enlutado tivesse deixado seu morto no passado e pudesse seguir em frente, o que corroborava a ideia de que o luto é algo a ser superado. Os autores destacam que a ideia da continuidade do vínculo era, até então, relacionada a um luto não-resolvido e patológico. Entretanto, a experiência clínica demonstra que o vínculo com o falecido continua durante a vida, mas é transformado para ser integrado à biografia do enlutado. Klass e Steffen

(2018) apontam que alguns fenômenos descritos pelos enlutados ratificam a continuidade dos vínculos, tais como: o senso de presença, a crença de que a pessoa morta continua influenciando pensamentos e alguns eventos da vida de quem fica, assim como a incorporação consciente de características e/ou valores do ente querido. A ideia do vínculo continuado é atualmente compreendida como um aspecto natural do processo pela maior parte dos modelos contemporâneos do luto.

Bowlby (2004), ao descrever os estágios do luto, afirmava que o ajustamento à perda envolveria o rearranjo e, talvez, uma nova sintonia emocional dos investimentos, mais do que um completo desligamento da pessoa que morreu. O processo de reorganização diz respeito a uma transformação do laço afetivo

concomitantemente à possibilidade do estabelecimento de novos vínculos $\mathrm{e}$ parcerias.

O Modelo de Processo Dual, proposto por Schut e Stroebe (1999), fornece uma estrutura analítica para compreender como as pessoas se adaptam à perda de um vínculo significativo. Muitas teorias focalizaram a questão do "trabalho de luto" no processo, o que significava que as pessoas precisavam se confrontar com suas perdas, passar por cima do que aconteceu antes e no momento da morte, focar nas memórias e trabalhar com o objetivo de se desligar da pessoa que morreu. 
De acordo com Stroebe e Schut (2001), há limitações em se compreender o luto apenas através da via do "trabalho de luto". O Modelo de Processo Dual incorpora o trabalho de luto, mas expande a maneira de compreender a adaptação a uma perda significativa. Este Modelo especifica a existência de dois tipos de estressores relacionados à adaptação à perda: orientados para a perda e orientados para a restauração. Essa diferenciação é necessária porque os enlutados lidam não apenas com a perda de uma pessoa querida, mas também precisam lidar com ajustes e tarefas que acontecem como consequências secundárias da perda. Os dois aspectos são fontes potenciais de estresse e ansiedade. $\mathrm{O}$ enfrentamento voltado para a perda refere-se a lidar com a perda, concentrar e trabalhar em cima de aspectos relacionados com a perda em si, tais como: chorar, anseio e saudade pela pessoa falecida, olhar fotografias, lembrar momentos e experiências, entre outros. O enfrentamento voltado para a restauração, por outro lado, refere-se a, por exemplo, assumir tarefas que antes eram do falecido, lidar com os novos arranjos da nova vida e desenvolver e assumir novos papéis.

Um aspecto importante deste modelo é que o enfrentar é voltado para a perda ou voltado para a restauração. Apesar de os dois tipos de enfrentamento serem interrelacionados, eles não podem ocorrer simultaneamente. De alguma maneira, o enlutado escolhe ignorar ou se concentrar em um dos lados do processo. Ao movimento dinâmico do processo de luto, Stroebe e Schut (2001) nomeiam de oscilação e afirmam que essa alternância é fundamental para a adaptação.

Neimeyer (2002) descreve profundas mudanças em relação à teoria e clínica do luto a partir do século XXI. Atualmente, há um ceticismo a respeito da universalidade de uma trajetória emocional previsível que pretende transportar o enlutado de um desequilíbrio psicológico a um reajustamento completo, não mais se considerando o luto com uma trajetória percorrida em fases pré-estabelecidas como as descritas por Kubler-Ross (1985). Em contrapartida, a compreensão do processo estaria ligada a padrões muito mais complexos de adaptação e não de adequação. Além disso, há um afastamento de uma presunção de que o luto bem sucedido requer a retirada da energia psíquica do falecido em direção à ideia do reconhecimento do papel potencialmente saudável dos laços contínuos simbólicos com o morto. Há ainda uma maior atenção às diversas esferas do luto (cognitiva, social, espiritual e comportamental) e não apenas aos aspectos emocionais do processo. $\mathrm{O}$ autor também pontua como importante desenvolvimento das teorias 
sobre o luto o fato de terem demonstrado maior consciência das implicações das perdas significativas no senso de identidade do enlutado, sendo muitas vezes necessárias profundas redefinições no senso de si mesmo.

Destaca-se aqui a importância dos rituais para o processo de luto. De acordo com Mitima-Verloop, Mooren e Boelen (2019), os rituais oferecem a oportunidade de expressão das emoções culturalmente aceitas relacionadas ao luto, além de marcarem a transição na qual a irreversibilidade da morte pode ser enfatizada. Os rituais também podem ser, segundo os autores, um ponto de partida para recuperação, além de serem um veículo no processo de transformação, transição e continuidade. Uma despedida com sentido é capaz de auxiliar o enlutado no processo de integração do luto.

Segundo Doka (2006), os funerais têm um papel terapêutico pois proporcionam um tempo delimitado para estar com outras pessoas, dividir memórias e receber suporte. É também uma oportunidade para fazer algo em um período que tudo parece tão desorganizado e estressante. Há um fazer envolvido na construção e presença nos rituais de luto. Eles reafirmam a realidade da morte ao mesmo tempo que são também uma oportunidade para expressar emoções. A presença em um ritual de despedida significativo beneficia os enlutados. 


\section{4 \\ Perda gestacional e neonatal e luto}

Perdas gestacionais e neonatais são comuns e podem ser devastadoras. Os abortos espontâneos (perda gestacional até a $22^{\mathrm{a}}$ semana de gravidez) são os tipos mais comuns de perdas perinatais, ocorrendo em $15 \%$ a $20 \%$ das gravidezes diagnosticadas, a maioria dentro das 13 primeiras semanas da gestação (Lee, McKenzie-McHarg e Horsch, 2017 e Oliveira et al, 2020). Em 2019, de acordo com dados do DataSus, ocorreram 29105 óbitos fetais (perda após a 22ª semana de gestação) no Brasil e dados demonstram que, no mundo, acontecem quase 3.000.000 de óbitos fetais anualmente. Apesar dos dados publicados, ainda parece ser difícil interpretá-los, uma vez que, as definições de aborto espontâneo e óbito fetal variam globalmente. Além disso, há dificuldade em se discutir o assunto, que ainda hoje, segue sendo silenciado e tratado como tabu.

A perda de um filho, comparada a outros tipos de luto como a perda de um parceiro ou de um irmão, é associada a reações de luto particularmente severas, com longa duração e complicadas. Porém, profissionais de saúde e a sociedade mais ampla costumam compreender o luto gestacional ou neonatal como menos traumático e menos prolongado do que o luto pela perda de uma criança mais velha ou de um adulto (Lang et al, 2011).

A reação dos pais em relação à perda de um filho durante o período gestacional ou pouco tempo após o parto é, muitas vezes, intensa e sofrida, pois, mesmo que seja previsível, parece muito difícil conciliar as realidades opostas da gravidez, como processo de origem da vida, e da morte (Tavares, 2013). Além disso, parece ser importante salientar que, enquanto o processo de luto pela perda de um adulto é, em grande parte retrospectivo, uma vez que envolve muitas lembranças do passado, o luto pela perda de uma criança ou de um bebê (mesmo que na gestação) torna-se prospectivo, já que envolve desejos, esperanças, fantasias e perspectivas para o futuro.

Salgado e Polido (2018) destacam o fato de que pais e mães que perdem seus bebês são privados de um projeto de vida, não apenas da convivência com o filho que estava sendo gestado. Há o luto pela perda em si e o luto pelo que não foi vivido. Há uma escassez de lembranças de alguém que já significava tanto para 
aquela família, pois a medida desse amor não é dada por tempo de gestação, mas sim pelo amor investido. Em muitos casos, as autoras destacam, a programação para a chegada do bebê é iniciada antes mesmo do teste positivo.

Alguns autores, entretanto, revelam que a natureza e a intensidade da experiência de luto são diferentes quando a perda acontece em uma gravidez mais avançada (Theut, et al, 1989). Essa diferença poderia estar relacionada, segundo Cassaday (2018), à intensidade da ligação física e emocional ao bebê, uma vez que, quanto mais a gravidez evolui, mais se escuta as batidas do coração do bebê, maior a quantidade de sinais e mudanças no corpo da mãe, mais a mãe sente o bebê se movimentando e mais vezes a família viu o bebê através de ultrassons.

As perdas gestacionais e neonatais detêm a especificidade de que compreendem, muitas vezes, perdas ocultas, uma vez que frequentemente são desconhecidas das outras pessoas ou não são reconhecidas como uma perda em si (Walsh \& McGoldrick, 1998). Segundo as autoras, uma das maiores preocupações das mães após uma perda gestacional ou neonatal está relacionada à sua capacidade de ter um filho em uma futura gravidez.

O conceito de luto não-reconhecido (disenfranchised grief) foi desenvolvido por Kenneth Doka (1989), que o define como um luto que acontece quando se tem uma perda significativa, mas que não é abertamente reconhecido, socialmente validado ou publicamente expressado. Ocorre quando o indivíduo vivencia o pesar, mas não há o reconhecimento social de que aquela pessoa tem o direito de se enlutar e de receber o suporte social adequado (Doka, 2008). Identifica-se luto não reconhecido nas seguintes circunstâncias: o relacionamento não é reconhecido; a perda não é reconhecida ou admitida; o enlutado não é reconhecido; a forma de enlutar-se não é reconhecida.

A impossibilidade de viver o luto pode partir da sociedade ou até mesmo do próprio enlutado, o que também pode trazer complicações para o processo. Ao reconhecer o luto, admite-se a realidade do impacto da perda, não o fazer pode ocorrer por ignorância de sua existência, por ambiguidades existentes ou para se defender de uma emoção que ele provoca (Casellato, 2015).

O luto não-reconhecido tem sido identificado como um possível complicador do processo de luto, uma vez que ao enlutado não é oferecido o suporte social adequado, além de, em algumas ocasiões, até o próprio enlutado não se perceber como alguém que vive uma condição específica e necessita de cuidados. 
Além disso, fatores que poderiam facilitar o processo estão, muitas vezes, ausentes nesse tipo de luto, uma vez que os enlutados podem não ter a oportunidade de ter um papel ativo na preparação dos rituais fúnebres, não decidem se desejam realizálo ou não ou sequer podem participar deles. (Doka, 2008).

As perdas gestacionais são tratadas, muitas vezes, como perdas socialmente negadas (Worden, 2013). É bastante frequente que uma perda no início da gestação não seja do conhecimento de todos e as famílias, especialmente as mães, podem se sentir constrangidas, evitando tocar no assunto da perda de um bebê nessas condições. Dessa forma, podem se sentir isoladas e desamparadas, não conseguindo receber suporte adequado, o que torna o processo de luto mais delicado e complexo. Worden (2013) afirma que preocupação sobre a capacidade de ter outros filhos, principalmente quando a perda acontece na primeira gestação, é bastante comum e fonte de grande ansiedade. Algumas famílias optam por tentar engravidar rapidamente, vislumbrando "sanar" essa dúvida e resolver o processo de luto.

Bowlby (2004) refere que nos casos de mortes intrauterinas e de crianças que nascem mortas, as reações à perda do filho são intensas e nem sempre reconhecidas como legítimas pela sociedade, o que pode impedir ou dificultar a elaboração dessa perda significativa. A perda gestacional ou neonatal pode gerar perturbações tão sérias para a estrutura familiar como a perda de uma criança mais velha.

Apesar de ser muitas vezes um luto não-reconhecido, a perda de um bebê deflagra reações de luto muito semelhantes a qualquer outro tipo de perda. Assim como em outros tipos de perda Cassaday (2018) afirma que, choque, descrença e entorpecimento são reações iniciais comuns frente a uma perda gestacional ou neonatal. A realidade da perda pode até mesmo ser negada para evitar a dor e o sofrimento. Para a autora, essas reações promovem proteção emocional frente a sobrecarga emocional da perda. São descritas também outras possíveis reações a esse tipo de perda como dor intensa, culpa, raiva, isolamento, tristeza, desespero que são sucedidas, em algum momento, por uma adaptação à perda e reconstrução da vida sem o bebê. É importante destacar, mais uma vez, que essas reações não são lineares ou sequenciais e, além disso, experiências anteriores, as circunstâncias em que a perda aconteceu, assim como o suporte recebido pela família, terão impacto importante na forma como o luto será vivenciado. 
A autorresponsabilização (culpa) é destacada por Worden (2013) como um aspecto primordial nas perdas gestacionais e neonatais. $\mathrm{O}$ autor afirma que a mulher precisa culpar alguém pelo ocorrido e se torna, muitas vezes o foco principal de recriminação. São comuns os pensamentos contrafactuais, que podem flutuar desde a possibilidade de construção de sentido para o que aconteceu como também podem se transformar em pensamentos ruminatórios que complicam o processo de luto (Eisma et al, 2019).

Os rituais de despedida são fundamentais para a realização da perda, assim como são uma oportunidade para os enlutados expressarem suas emoções e receberem suporte dentro desse ambiente circunscrito (Doka, 2006). Entretanto, em situações de luto por perda gestacional ou neonatal, os pais, e, especialmente, as mães, são por vezes desencorajados a participarem dos funerais de seus bebês. Porém, segundo o autor, é crucial que se leve em consideração a capacidade que os indivíduos têm de fazerem suas escolhas, mesmo que em condição de maior vulnerabilidade, como a deflagrada por uma perda significativa. Para algumas pessoas, a ideia de que esse evento é triste demais ou que o enlutado não terá condições de encará-lo, coloca a pessoa que passou por uma perda em uma posição não só de fragilidade, mas de incapacidade. Para Doka (2006), mais do que fazer a escolha pelo enlutado se ele deve ou não comparecer, é possível ajudá-lo a fazer a própria escolha. Quando opções são dadas, os enlutados também são capazes de escolher o que desejam para esse momento. Eles podem participar de uma parte do ritual, ficar apenas por um tempo e, mesmo se desejarem não comparecer, podem ajudar na sua elaboração, assim como também podem construir um ritual de despedida individual e significativo.

A dificuldade da família enlutada em fazer as próprias escolhas não diz respeito apenas à participação nos rituais de despedida, mas, também parece haver obstáculos para a equipe de saúde apresentar as possibilidades de procedimentos, uma vez que, muitas vezes, há pressa na resolução da gestação. Segundo Salgado e Polido (2018), acelerar o processo de resolução técnica da gravidez, na tentativa de poupar todos de lidarem com a morte (inclusive a própria equipe de saúde) pode até trazer algum conforto imediato. Porém, é preciso que a estratégia seja discutida e elaborada levando em consideração as demandas emocionais e psíquicas não só da mulher como de sua família, assim como também precisam se considerados os impactos físicos e emocionais de médio e longo prazo. 
Um possível complicador para a vivência do luto perinatal está ligado à dificuldade que hospitais e equipe de saúde têm para lidar com a morte e a perda. De acordo com Salgado e Polido (2018), a maior parte dos profissionais que oferecem assistência em saúde são treinados para oferecer cuidados qualificados, mas não estão preparados para comunicar a morte de um bebê, visto que essa não é esperada no contexto do nascimento. As autoras destacam o fato de que até mesmo o pré-natal é idealizado para afastar famílias e equipe da experiência de morte. A falta de preparo faz com que as unidades de saúde e equipes não saibam como prestar o cuidado adequado. São inúmeros os relatos de mulheres que tiveram seus bebês mortos ao lado de uma mãe que recebia o bebê vivo, de mães que ganharam kits de bebê nas maternidades, receberam felicitações pela chegada do bebê ou foram perguntadas sobre o horário de amamentação. Salgado e Polido (2018) acrescentam que, mesmo que a equipe de saúde também esteja impactada emocionalmente pela morte do bebê, a família é, certamente, quem está mais triste e mais chocada com a perda e, portanto, deve receber cuidados e suporte adequados. Para isso, é necessário que essas questões sejam discutidas na rotina do serviço e que todos recebam o treinamento adequado para garantia do mínimo de bem-estar, respeito e dignidade para todos. A instituição de saúde deve treinar profissionais e equipes para atenderem homogeneamente e coletivamente os casos de perda gestacional e neonatal. Todos precisam estar treinados, não só a equipe de saúde, mas todos que ali trabalham, incluindo recepcionistas e colaboradores de serviços

Por outro lado, receber o suporte adequado é um importante facilitador para o processo de luto das famílias. Mendonça (2018) identifica o suporte social como um fator protetor passível de se assumir como recurso de apoio a mulheres que experienciaram uma perda gestacional ou neonatal. De acordo com a autora, o suporte social é definido como a existência ou disponibilidade de pessoas em quem pode confiar, além de dizer respeito aos recursos que a pessoa tem a seu dispor para dar reposta a seus pedidos de ajuda e assistência.

Volkmer (2016) explicita algumas recomendações destinadas aos profissionais de saúde para facilitação do processo de luto dos pais, tais como a necessidade de se informar imediatamente sobre a condição do bebê explicando os fatos, quando disponíveis; expressar sentimentos sobre a perda com palavras que possam consolar os pais, assim como tocá-los, de maneira afetuosa e oportuna, encorajar que os pais vejam e segurem o bebê e, finalmente, reconhecer que os pais 
tiveram uma perda real. É fundamental ressaltar, entretanto, que esse contato precisa ser empático e conectado com os pais, sendo necessário respeitar o momento e os limites de cada família. Recomenda-se, também, que sejam evitados clichês, como "você é jovem e terá outros filhos", "foi melhor assim", entre outros.

Atualmente, apesar das dificuldades em relação ao suporte dado pelas equipes de saúde às famílias que vivenciam perda gestacional ou neonatal, muito também vem sendo desenvolvido para que pais e mães recebam o cuidado adequado. Üstündağ-Budak et al (2015) afirmam que, se até a década de 70 o padrão era evitar que as famílias vissem os bebês mortos, atualmente, muito vem sendo feito para facilitar o processo de luto das famílias. Os autores citam exemplos de estratégias criadas pelas equipes para que os pais construam memórias com seus bebês, além de incentivarem as famílias a darem nomes aos filhos e encorajarem, especialmente as mulheres a verem e, se possível, segurarem seus bebês. Afirmam que ver o bebê morto parece ser realmente importante para o processo de luto.

É importante destacar, entretanto, que uma pesquisa realizada por Hughes et al (2002) apontou que mulheres que não viam seus bebês após uma perda tinham menos chance de desenvolverem depressão em uma gravidez subsequente. Além disso, essas mulheres também apresentaram menos sintomas de ansiedade e TEPT. Apesar de ser um estudo controverso, os dados descritos por Hughes et al (2002) são importantes para ressaltar a singularidade e individualidade de cada um dos processos de perda, não sendo possível existir uma regra a ser aplicada a qualquer pessoa em qualquer circunstância. Os protocolos podem e devem existir nas unidades de saúde, entretanto, o cuidado da singularidade precisa ser sempre soberano.

Salgado e Polido (2018) afirmam que quando há tempo para se preparar para a chegada do bebê após a perda, são maiores as chances de que a família queira ver o filho imediatamente após o parto. Por outro lado, quando a perda é repentina e o parto acontece em caráter de emergência ou quando todos são surpreendidos pela chegada de um bebê sem vida, é mais comum que as famílias rejeitem o contato. As autoras afirmam que não há certo e errado sobre o que fazer, destacando o fato de que as famílias precisam ser acolhidas em sua decisão. Entretanto, é fundamental que as equipes estejam abertas e disponíveis para o acolhimento e suporte na tomada de decisão. Em muitas situações, acrescentam as autoras, as mães sequer 
estão conscientes para fazerem a escolha e o parceiro, muitas vezes fragilizado e sozinho, pode não conseguir refletir adequadamente sobre ver ou não ver o filho.

Segundo Lee, McKenzie-McHarg e Horsch (2017), aproximadamente 86\% das mulheres que vivenciam uma perda perinatal engravidam novamente nos 18 meses seguintes. Afirmam que, apesar da maioria das mães se adaptar à perda com o passar do tempo, uma pequena parcela experimenta dificuldades psicológicas que se estendem à gravidez subsequente, incluindo reações de luto intensas, ansiedade específica relacionada à gravidez, estresse e depressão, além de transtorno de estresse pós-traumático. Ademais, mulheres grávidas que vivenciaram perdas gestacionais ou neonatais, tendem a viver a gravidez seguinte como estressante e perceber o risco de uma perda recorrente como forte ameaça.

De acordo com a pesquisa de Volkmer (2009), após perdas desse tipo, as mulheres buscavam se afastar da possibilidade de uma nova perda, afirmando que não queriam engravidar novamente. Entretanto, essa decisão se modificava e voltavam a engravidar algum tempo depois. Segundo a autora, a nova gravidez acontecia por redução do sofrimento relacionado à perda com o passar do tempo, uso inadequado de contraceptivos e forte influência do desejo do parceiro em ter outro filho. A partir da confirmação da gravidez, muitas tentavam não se vincular afetivamente ao bebê, como estratégia de enfrentamento, especialmente no período inicial da gestação. Para evitar o vínculo afetivo, não davam nome ao bebê, não contavam para os amigos, além demorarem para comprar qualquer peça do enxoval.

Lee, Mc-Kenzie-McHarg e Horsch (2013) verificaram que mulheres que engravidavam após uma perda gestacional experienciavam uma mistura de emoções relacionadas ao luto, ansiedade específica e culpa. Para minimizar o estresse durante nova gestação, buscavam não pensar ou falar sobre a perda e, também sobre a nova gravidez. Buscavam não se aproximar de outras mulheres grávidas. Ao mesmo tempo, era muito importante que os outros soubessem da existência do bebê que foi perdido. As mulheres queriam passar a mensagem de que a gravidez não era substituição do bebê perdido e que ainda estavam enlutadas pela perda e, para muitas, dizer isso era fundamental.Reid (2007) afirma que os bebês que nascem após uma perda neonatal ou gestacional ou depois da morte de uma criança pequena, costumam nascer sob a sombra do bebê perdido, mais do que como uma substituição, sendo por ela nomeados como bebê penumbra. De acordo com a autora, o vínculo entre a mãe e o bebê morto às vezes parece ser tão forte que 
o que resta para o novo bebê é uma área obscura e incerta que a mãe parece ter dificuldade de explorar.

Segundo Rato (1998), a experiência de perda de um bebê durante a gravidez ou logo após o parto, poderia trazer como repercussão a projeção de sua sombra sobre o que aconteceria no futuro. Uma gravidez anterior com final infeliz poderia assombrar a perspectiva da gravidez seguinte. Para a autora, a possível criança que chega após a perda encontra-se, a princípio, em uma situação difícil, uma vez que será confrontada com o bebê imaginário, podendo até ser confundida com o bebê morto. A partir dessa afirmação, podemos refletir sobre as possíveis repercussões do luto por perda gestacional na interação e vinculação entre a mãe e o bebê, assim como questionar ou ponderar sobre a utilização do termo bebê arco-íris para designar o filho que chega após uma perda como essa.

Em mulheres com história de perda perinatal, Gaudet et al (2010) referem que em situação de gravidez precoce após a perda, o estágio em que a perda aconteceu na gravidez anterior, a experiência de uma perda tardia e um alto número de perdas são fatores de risco para os sintomas do luto, alta ansiedade e apego reduzido em relação a essa nova gestação.

Os desafios vivenciados em uma gravidez subsequente à perda costumam não ser reconhecidos e validados pela sociedade, que costuma perceber a gravidez como algo positivo, feliz. A decisão de tenta engravidar novamente depois de uma perda gestacional ou neonatal pode disparar emoções conflituosas, dúvidas, inseguranças e preocupações. Além disso, de acordo com Lee, McKenzie-McHarg e Horsch (2013), pais referem receber conselhos contraditórios em relação a quanto tempo deveriam esperar antes de uma nova tentativa de engravidar após a perda. Em relação a essa decisão de engravidar ou não, as famílias também gostariam que os profissionais de saúde fornecessem informações relevantes relacionadas a uma futura gravidez para que pudessem tomar uma decisão pessoal informada. Essa decisão também é influenciada por uma gama de fatores que inclui a idade da mãe, já ter ou não outros filhos, medo de infertilidade, sentir-se pronta para engravidar novamente e o momento do processo de luto após a perda. Os autores chamam atenção para o fato de que uma gravidez subsequente a uma perda tem como repercussão, muitas vezes, o aumento da ansiedade e da preocupação em relação à gestação e ao seu resultado final. Além disso, muitas mulheres relatam a perda de sentimentos como a inocência e a plena alegria em estar grávidas. Engravidar passa 
a não ser mais um ato inocente em que tudo tende a dar certo e ter um final feliz e passa a ser fonte de ansiedade, preocupação e medo profundos, capazes de impactar na vinculação com o bebê ainda na barriga assim como nas primeiras interações entre mãe e bebê.

Armstrong (2002) desmistifica a crença, através dos resultados de sua pesquisa, de que uma nova gravidez é capaz de diminuir o luto e as preocupações. Os dados encontrados, em oposição à ideia de que uma nova gravidez resolve o luto, identificam a gestação subsequente como um período muito estressante para a família.

Lee, Mc-Kenzie-McHarg e Horsch (2013) identificaram estratégias utilizadas por mães em gravidezes posteriores à perda para manter a esperança de que essa gravidez resultaria no nascimento de um bebê vivo. São elas: aceitação do desfecho da gravidez (o que tiver de ser, será); evitação (não pensar, falar ou ler sobre gravidez subsequente e encobrir/disfarçar a gravidez); guardar as emoções; viver o presente; focar em pequenos marcos; resistir ao apego (evitar preparação da chegada, por exemplo); preparação para dificuldades na gravidez e possível perda; pensar positivamente sobre o futuro.

Armstrong (2002) salienta a importância da compreensão dos altos e baixos que as famílias enfrentam durante uma gravidez subsequente a uma perda perinatal, pois essa atenção pode promover um melhor cuidado. Segundo a autora, os profissionais de saúde precisam estar atentos à mistura de sentimentos como medo e esperança em situações como essa. O entendimento e oferecimento do suporte adequado podem influenciar significativamente o curso da gravidez e o vínculo futuro entre pais e filhos.

De acordo com Al et al (2016), crianças que nascem após uma perda perinatal podem experimentar dificuldades em relação ao apego devido ao resultado direto da perda ou ao impacto na saúde mental da mãe. O processo de vinculação pode ser inibido por algumas variáveis, como experiência negativa do nascimento, depressão, ansiedade, todas associadas com a perda. Além disso, os autores destacam que essas mães podem perceber os bebês que chegam após a perda como menos ideais do que as mães que não tiveram perda gestacional ou neonatal, assim como também podem ter mais problemas em relação a questões de sono, choro e alimentação do que mães que não vivenciaram perdas. 
As mães enlutadas podem ter dificuldade em se vincular com o novo bebê e a criança nascida após uma perda perinatal pode vir a ter problemas psicológicos relacionados a superproteção ou a pais muito controladores. Os comportamentos de superproteção podem surgir tanto da Síndrome do Bebê de Substituição comparação da criança com um bebê ideal que foi perdido, sendo os comportamentos controladores da mãe uma tentativa de conter os sentimentos agressivos (Cain e Cain, 1964), como da Síndrome da Criança Vulnerável (Green e Solnit, 1964) - ansiedade dos pais sobre a saúde da criança, percebem a criança como mãos frágil e comportamentos de controle da mãe podem estar relacionados à ansiedade acerca de doença futura e morte. 


\section{5 Justificativa}

A partir da experiência clínica com mães enlutadas após perda gestacional ou neonatal, foi identificada ambivalência de sentimentos entre medo e o grande desejo por uma nova gravidez. Em algumas situações, esse desejo foi relatado imediatamente após a perda e, em outras, foi sendo construído e elaborado ao longo do processo terapêutico. Surge então, a necessidade de investigar de que maneira o processo de luto poderia interferir na construção e desenvolvimento do vínculo da mãe com esse bebê identificado como bebê arco-íris - aquele que chega depois da tempestade.

A compreensão dos impactos do luto advindo desse tipo de perda sobre a mãe e suas consequências no desenvolvimento do vínculo com o novo bebê apresentam a necessidade de construção e implementação de estratégias que possam prevenir possíveis complicações e promovam saúde na relação da díade mãe-bebê. 
6

\section{Objetivos}

\section{1}

\section{Objetivo geral}

- Investigar as repercussões da perda gestacional ou neonatal prévia no processo de construção do vínculo da mãe com o bebê que nasce durante o processo de luto.

\section{2}

\section{Objetivos específicos}

- Investigar características das primeiras interações da mãe e seu bebê.

- Investigar os fatores que prevalecem no processo de luto.

- Investigar as possíveis repercussões do processo de luto na construção do vínculo mãe-bebê, através das primeiras interações estabelecidas. 


\section{7 \\ Metodologia}

\section{1}

\section{Participantes}

Inicialmente buscou-se entrevistar 20 mulheres, apenas residentes na cidade do Rio de Janeiro, que tivessem tido ao menos uma perda gestacional ou neonatal e com um novo bebê de até 12 meses. Entretanto, diante do cenário da pandemia da Covid-19 e da dificuldade de encontrar número suficiente de participantes nesse perfil, ampliou-se o escopo da pesquisa para mulheres brasileiras, maiores de 18 anos, que tivessem tido perda gestacional ou neonatal sem limite de idade para o novo bebê. Foram realizadas 17 entrevistas. Esquematizou-se, abaixo, o perfil das entrevistadas com as seguintes características:

\begin{tabular}{|c|c|c|c|c|c|c|}
\hline $\begin{array}{l}\text { Nome } \\
\text { Fictício }\end{array}$ & Idade & Profissão & Escolaridade & $\begin{array}{c}\text { Estado } \\
\text { civil }\end{array}$ & $\begin{array}{l}\text { Estado de } \\
\text { residência }\end{array}$ & $\begin{array}{c}\text { Número de } \\
\text { perdas/Tempo de } \\
\text { gestação }\end{array}$ \\
\hline E1 & $\begin{array}{c}30 \\
\text { anos }\end{array}$ & $\begin{array}{l}\text { Servidora } \\
\text { pública }\end{array}$ & $\begin{array}{l}\text { Superior } \\
\text { completo }\end{array}$ & Casada & RJ & $\begin{array}{c}1 \\
\text { (12 semanas) }\end{array}$ \\
\hline E2 & $\begin{array}{c}45 \\
\text { anos }\end{array}$ & Jornalista & $\begin{array}{l}\text { Superior } \\
\text { completo }\end{array}$ & Casada & $\mathrm{RJ}$ & $\begin{array}{c}3 \\
(7 \mathrm{sem} / 7 \mathrm{sem} / 5 \mathrm{sem})\end{array}$ \\
\hline E3 & $\begin{array}{c}40 \\
\text { anos }\end{array}$ & $\begin{array}{c}\text { Administradora } \\
\text { de empresas }\end{array}$ & $\begin{array}{l}\text { Superior } \\
\text { completo }\end{array}$ & Casada & RJ & $\begin{array}{c}1 \\
\text { (39 semanas) }\end{array}$ \\
\hline E4 & $\begin{array}{c}45 \\
\text { anos }\end{array}$ & Psicóloga & $\begin{array}{l}\text { Superior } \\
\text { completo }\end{array}$ & Casada & $\begin{array}{l}\text { Lisboa } \\
\text { Portugal }\end{array}$ & $\begin{array}{c}2 \\
(8 \mathrm{sem} / 11 \mathrm{sem})\end{array}$ \\
\hline E5 & $\begin{array}{c}37 \\
\text { anos }\end{array}$ & $\begin{array}{l}\text { Analista de } \\
\text { sistemas }\end{array}$ & $\begin{array}{l}\text { Superior } \\
\text { completo }\end{array}$ & Casada & $\mathrm{RJ}$ & $\begin{array}{c}1 \\
\text { (14 semanas) }\end{array}$ \\
\hline E6 & $\begin{array}{c}35 \\
\text { anos }\end{array}$ & Psicóloga & Mestrado & Casada & BA & $\begin{array}{c}1 \\
\text { (9 semanas) }\end{array}$ \\
\hline E7 & $\begin{array}{c}39 \\
\text { anos }\end{array}$ & Psicóloga & $\begin{array}{c}\text { Pós- } \\
\text { graduação }\end{array}$ & Casada & $\mathrm{RJ}$ & $\begin{array}{c}1 \\
\text { (17 semanas) }\end{array}$ \\
\hline E8 & $\begin{array}{c}37 \\
\text { anos }\end{array}$ & Psicóloga & Mestrado & Casada & $\mathrm{RJ}$ & $\begin{array}{c}1 \\
\text { (6 semanas) }\end{array}$ \\
\hline
\end{tabular}




\begin{tabular}{|c|c|c|c|c|c|c|}
\hline E9 & $\begin{array}{c}31 \\
\text { anos }\end{array}$ & Psicóloga & $\begin{array}{c}\text { Pós- } \\
\text { graduação }\end{array}$ & Casada & $\mathrm{GO}$ & $\begin{array}{c}1 \\
(9 \text { semanas })\end{array}$ \\
\hline E10 & $\begin{array}{c}33 \\
\text { anos }\end{array}$ & Perita Criminal & $\begin{array}{c}\text { Pós- } \\
\text { graduação }\end{array}$ & Casada & $\mathrm{GO}$ & $\begin{array}{c}3 \\
(9 \mathrm{sem} / 11 \mathrm{sem} / 9 \mathrm{sem})\end{array}$ \\
\hline E11 & $\begin{array}{c}22 \\
\text { anos }\end{array}$ & Estudante & $\begin{array}{l}\text { Ensino médio } \\
\text { incompleto }\end{array}$ & Casada & RJ & $\begin{array}{c}1 \\
(29 \text { sem })\end{array}$ \\
\hline E12 & $\begin{array}{c}39 \\
\text { anos }\end{array}$ & Advogada & $\begin{array}{l}\text { Superior } \\
\text { completo }\end{array}$ & Casada & $\mathrm{RJ}$ & $\begin{array}{c}1 \\
\text { (20 semanas) }\end{array}$ \\
\hline E13 & 36 & Médica & $\begin{array}{l}\text { Pós- } \\
\text { graduação }\end{array}$ & Casada & SP & $\begin{array}{c}2 \\
(9 \operatorname{sem} / 6 \operatorname{sem})\end{array}$ \\
\hline E14 & $\begin{array}{c}43 \\
\text { anos }\end{array}$ & Enfermeira & $\begin{array}{l}\text { Pós- } \\
\text { graduação }\end{array}$ & Casada & $\mathrm{RJ}$ & $\begin{array}{c}3 \\
(8 \mathrm{sem} / 9 \mathrm{sem} / 4 \mathrm{sem})\end{array}$ \\
\hline E15 & $\begin{array}{c}33 \\
\text { anos }\end{array}$ & Contadora & $\begin{array}{c}\text { Pós- } \\
\text { graduação }\end{array}$ & Casada & $\mathrm{RS}$ & $\begin{array}{c}1 \\
\text { (22 semanas) }\end{array}$ \\
\hline E16 & $\begin{array}{c}31 \\
\text { anos }\end{array}$ & $\begin{array}{c}\text { Gastrônoma } \\
\text { Professora }\end{array}$ & $\begin{array}{c}\text { Pós- } \\
\text { graduação }\end{array}$ & Casada & DF & $\begin{array}{c}1 \\
\text { (30 semanas) }\end{array}$ \\
\hline E17 & $\begin{array}{c}39 \\
\text { anos }\end{array}$ & Advogada & Mestrado & Solteira & RJ & $\begin{array}{c}1 \\
\text { (perda neonatal - } \\
29 \text { sem - } \\
\text { sobreviveu } 2 \text { dias) }\end{array}$ \\
\hline
\end{tabular}

\section{2 \\ Procedimentos de coleta e análise dos dados}

A coleta de dados foi realizada através de entrevista com roteiro semiestruturado (Anexo I) na tentativa de abordar os objetivos centrais a serem investigados na presente pesquisa. As entrevistas foram gravadas e transcritas para posterior análise dos dados.

As participantes da pesquisa foram selecionadas através de chamada em rede social e, também, através de indicação. Em virtude da pandemia pela COVID19, os dados foram todos coletados através da plataforma online ZOOM. As entrevistas foram gravadas e transcritas em sua íntegra, posteriormente.

Para a análise e interpretação dos dados obtidos, a partir das entrevistas foi utilizada a técnica de análise de conteúdo proposta por Bardin (1977), que consiste 
na leitura da transcrição das entrevistas realizadas, com o objetivo de investigar as relações existentes entre os conteúdos presentes no discurso dos participantes. Foram percorridas as três etapas que são pertinentes à análise temática: pré-análise, exploração do material e tratamento/interpretação dos resultados obtidos.

Em seguida, os dados foram agrupados segundo as categorias identificadas no material coletado, tendo como eixos condutores o processo de luto vivenciado após a perda e as primeiras interações com o bebê. A partir dessa etapa, foram selecionados trechos do material considerados relevantes à constituição das categorias de análise ou unidades de significação, dando origem aos temas. Durante a fase de interpretação dos dados, foi realizado um retorno ao referencial teórico utilizado para a construção da pesquisa, buscando embasar as análises.

Com o objetivo de avaliar a frequência das palavras apresentadas no discurso das participantes, foi utilizado o software IRaMuTeQ. Este possibilita a realização de diferentes tipos de análises estatísticas sobre corpus textuais e tabelas indivíduos/palavras (Camargo \& Justo, 2013).

Inicialmente, o corpus textual foi preparado para a análise. Após preparação do corpus, foi realizada uma análise lexicográfica para calcular a frequência das palavras e uma classificação hierárquica descendente (CHD), obtendo classes que apresentam vocabulários semelhantes entre si. A partir dessas classes, foi possível identificar a presença de determinados vocabulários utilizados para descrição dos processos investigados (vinculação - a partir das interações estabelecidas e luto). Por fim, foi gerada uma nuvem de palavras, que agrupa e organiza, graficamente, as palavras em função de sua frequência (Camargo \& Justo, 2013).

\section{3}

\section{Cuidados éticos}

A pesquisa seguiu as normas da Comissão Nacional de Ética em Pesquisa (CONEP, Conselho Nacional de Saúde, Ministério da Saúde, Brasil) e do Código de ética Profissional dos Psicólogos, além de atender às exigências estabelecidas pela Resolução 510/16 do Conselho Nacional de Saúde. Foi submetida e aprovada pelo Comitê de Ética da PUC-Rio sob o Protocolo 15/2020.

Às participantes foi apresentado o termo de consentimento livre e esclarecido (Anexo II), informando a estas os objetivos da pesquisa, bem como a 
relevância social desta. A participação nessa pesquisa não apresentou custos às participantes, nem vantagens financeiras. Quanto a possíveis danos, ressaltamos o risco mínimo desta que foi reduzido pela possibilidade de a participante não responder à pergunta, ou mesmo solicitar o encerramento da entrevista, assim como, se avaliada a necessidade, oferecido encaminhamento para atendimento psicológico sem custo. Foram utilizados somente os dados das participantes que assinaram o referido termo para a construção dessa dissertação de Mestrado. Cabe ressaltar que todas as informações que possam identificar as participantes foram mantidas em sigilo, a fim de conservar a privacidade das mesmas. 


\section{8 \\ Resultados e Discussão}

O corpus geral foi constituído por 17 textos separados em 3303 segmentos de texto com aproveitamento de 2916 St (88,28\%). Emergiram 110960 ocorrências (proposições, palavras, formas ou vocábulos) sendo 3942 palavras distintas e 1591 palavras com uma única ocorrência.

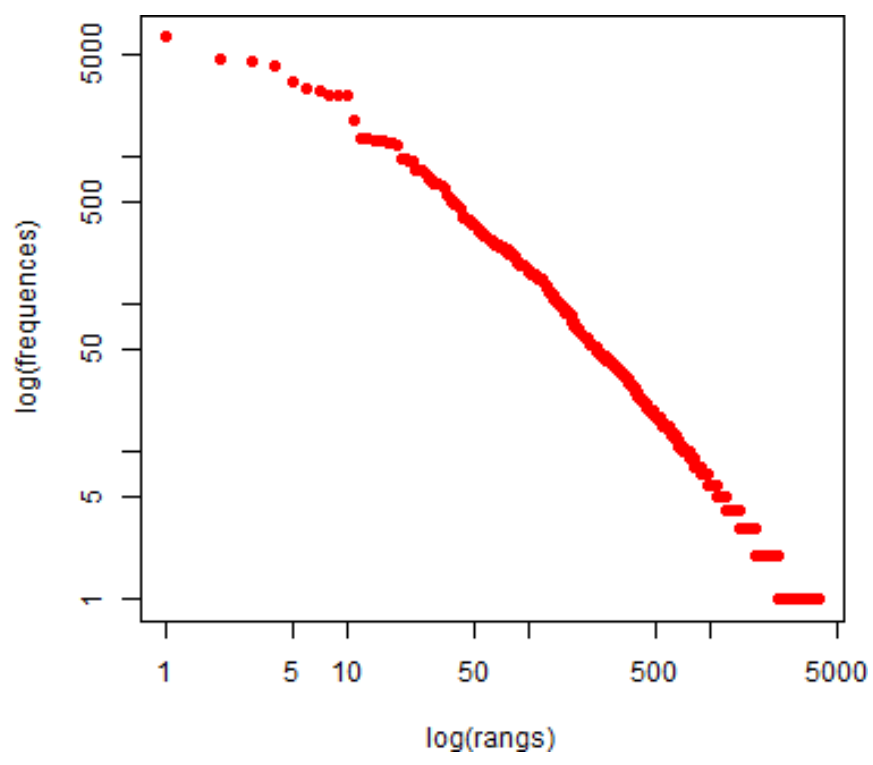

Figura 1 - Frequência de palavras X repetição de palavras

A figura 1 demonstra ao lado esquerdo (Frequência), as palavras que emergiram do corpus e que se repetiram apenas uma vez, enquanto o lado direito (Variância), revelou as palavras que se repetiram muitas vezes dentro do corpus textual.

O conteúdo foi categorizado em quatro classes:

- Classe 1 com 550 segmentos de textos $(18,9 \%)$;

- Classe 2 com 625 segmentos de textos $(21,4 \%)$;

- Classe 3 com 943 segmentos de textos (32,3\%);

- Classe 4 com 798 segmentos de textos $(27,4 \%)$. 


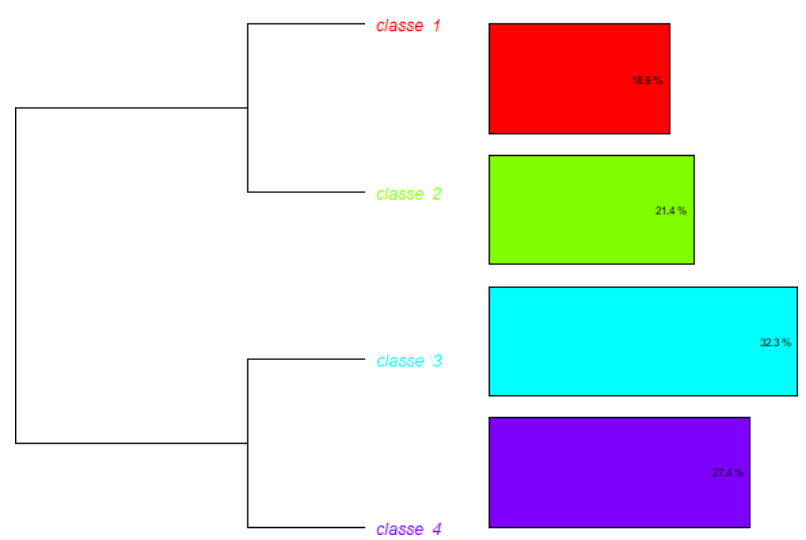

Figura 2 - Classificação das palavras por classes (\%)

Outra forma de apresentação dos dados revelou as palavras agrupadas nas diferentes classes apresentadas pelo gráfico abaixo.

As classes 3 e 4 estão relacionadas à experiência de perda/luto e ao vínculo e cuidado com o bebê que chega após essa experiência, respectivamente. Em relação à classe 3 (perda e luto), chamam atenção duas das palavras que mais aparecem - achar e saber - que apontam para busca e construção de sentido e significado para essa perda. Do outro lado dessa ramificação - classe 4 - aparecem questões referentes à construção de vínculo e ao cuidado relacionados ao bebê que chega após a perda gestacional ou neonatal.

A classe 1 está relacionada à gestação e a anseios, medos e desejos ligados à gravidez. A classe 2 apresenta palavras ligadas a questões médicas relacionadas à gravidez, possíveis problemas e formas de detectá-los.

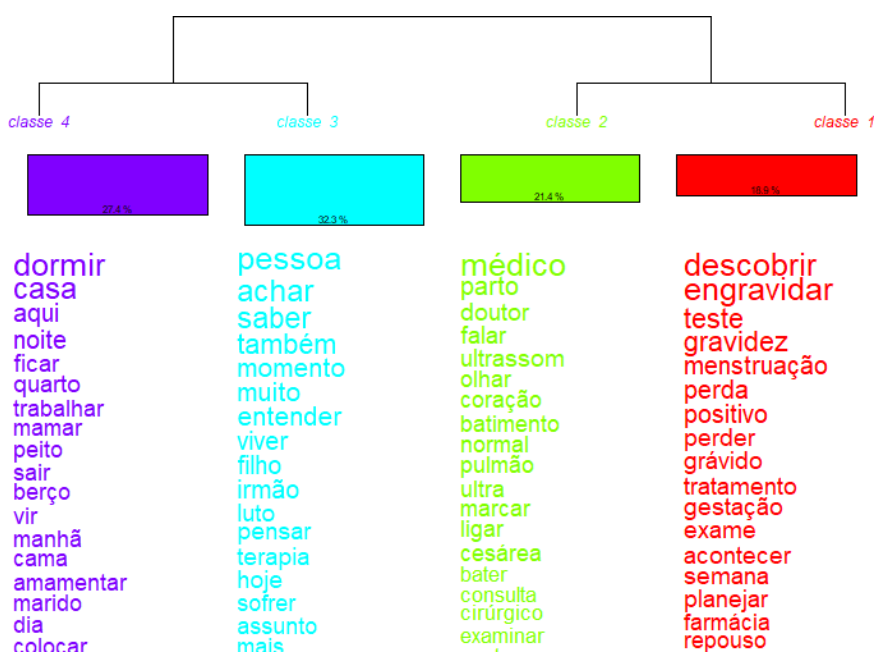

Figura 3 - Palavras agrupadas por classes 
Pela Análise Fatorial por Correspondência foi possível realizar a associação do texto entre as palavras, levando em consideração a frequência de incidência destas e suas classes, que foram representadas em um plano cartesiano. Através da Figura 4, observou-se que as palavras das classes tenderam a uma expansão periférica, contudo houve algumas palavras que se apresentaram em um segmento centralizado. Nesta apresentação foi possível visualizar como as classes se ramificaram e como algumas ficaram em sobreposição.

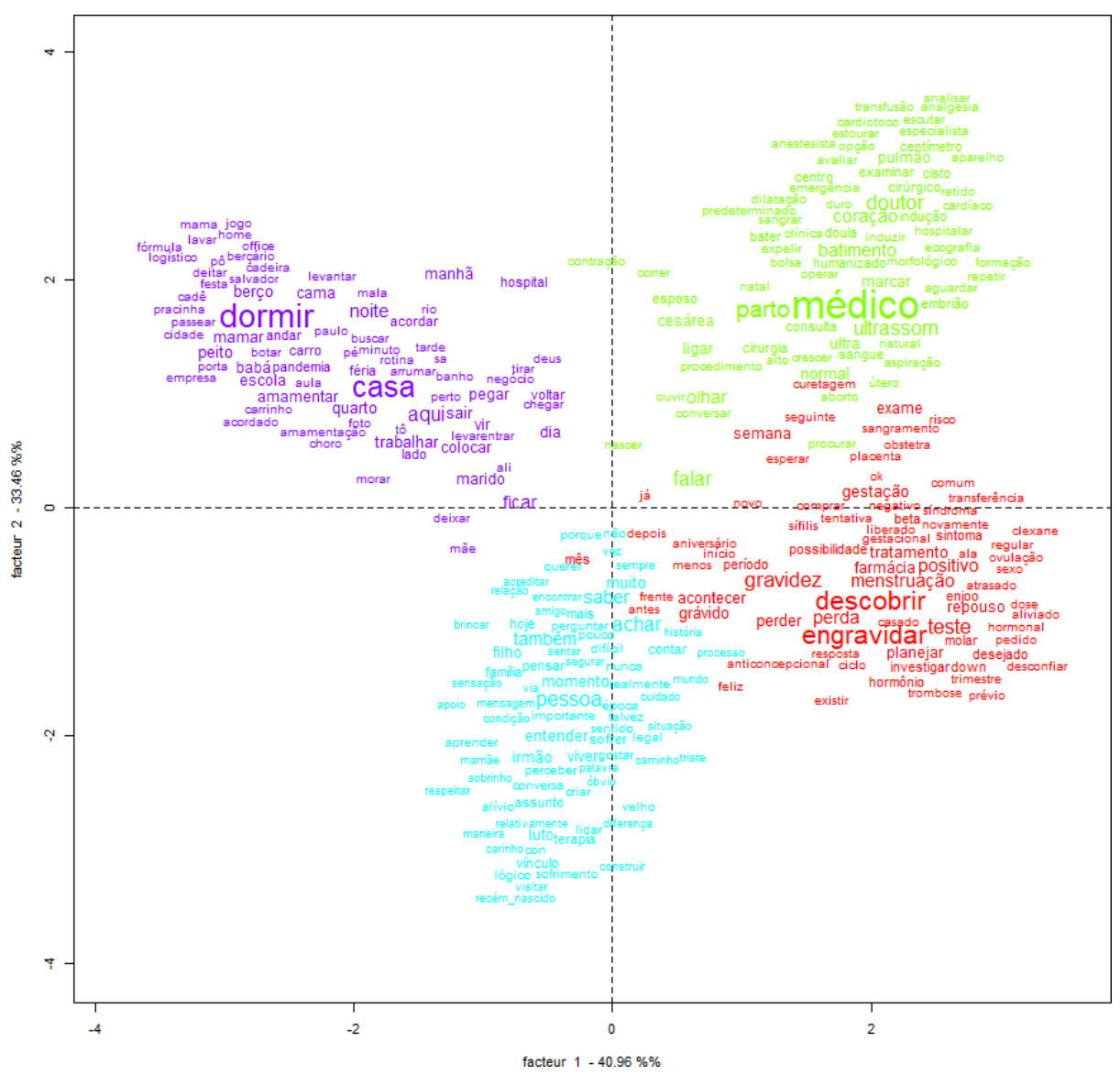

Figura 4 - Análise Fatorial por Correspondência indicando a frequência de palavras e classes

Em seguida, foi criada a nuvem de palavras obtida por meio das entrevistas. As palavras mais evocadas foram: não, falar, porque, saber o que demonstra a dificuldade de se falar abertamente sobre o tema da perda gestacional e neonatal. Além disso, parece ser muito importante a busca por saber e compreender os porquês em relação ao ocorrido, assim como a possibilidade de construir sentido para a perda. 


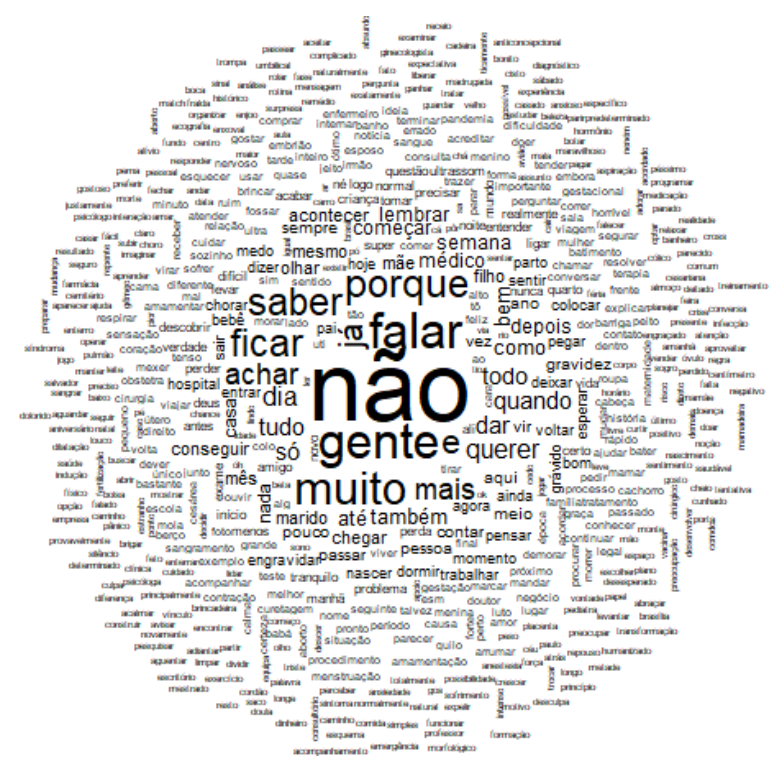

Figura 5 - Nuvem de palavras

\section{1 \\ Análise das entrevistas}

As repostas obtidas a partir da realização das entrevistas permitiram investigar o impacto da perda gestacional no desejo e decisão de engravidar novamente. Além disso, foi possível aprofundar a compreensão sobre a maneira como a perda e o luto podem influenciar na construção de vínculo com o novo bebê ainda durante a gestação e nas primeiras interações. A partir da análise de conteúdo realizada, foi possível traçar as categorias que serviram como eixo norteador das perguntas da entrevista.

\begin{tabular}{|l|l|}
\hline Categorias de Análises - PERDA & Informações obtidas \\
\hline Desejo de engravidar & $\begin{array}{l}\text { E3: Eu engravidei e meu primeiro filho já tinha } \\
\text { três anos. Foi super planejada. Foi super } \\
\text { planejada. Foi uma gravidez, é dentro assim... } \\
\text { com a diferença de idade que eu queria. } \\
\text { E4: Queria sim. Tava casada há uns quatro anos, } \\
\text { já tinha aproveitado bastante e era um desejo } \\
\text { meu e do meu marido. }\end{array}$ \\
\hline
\end{tabular}




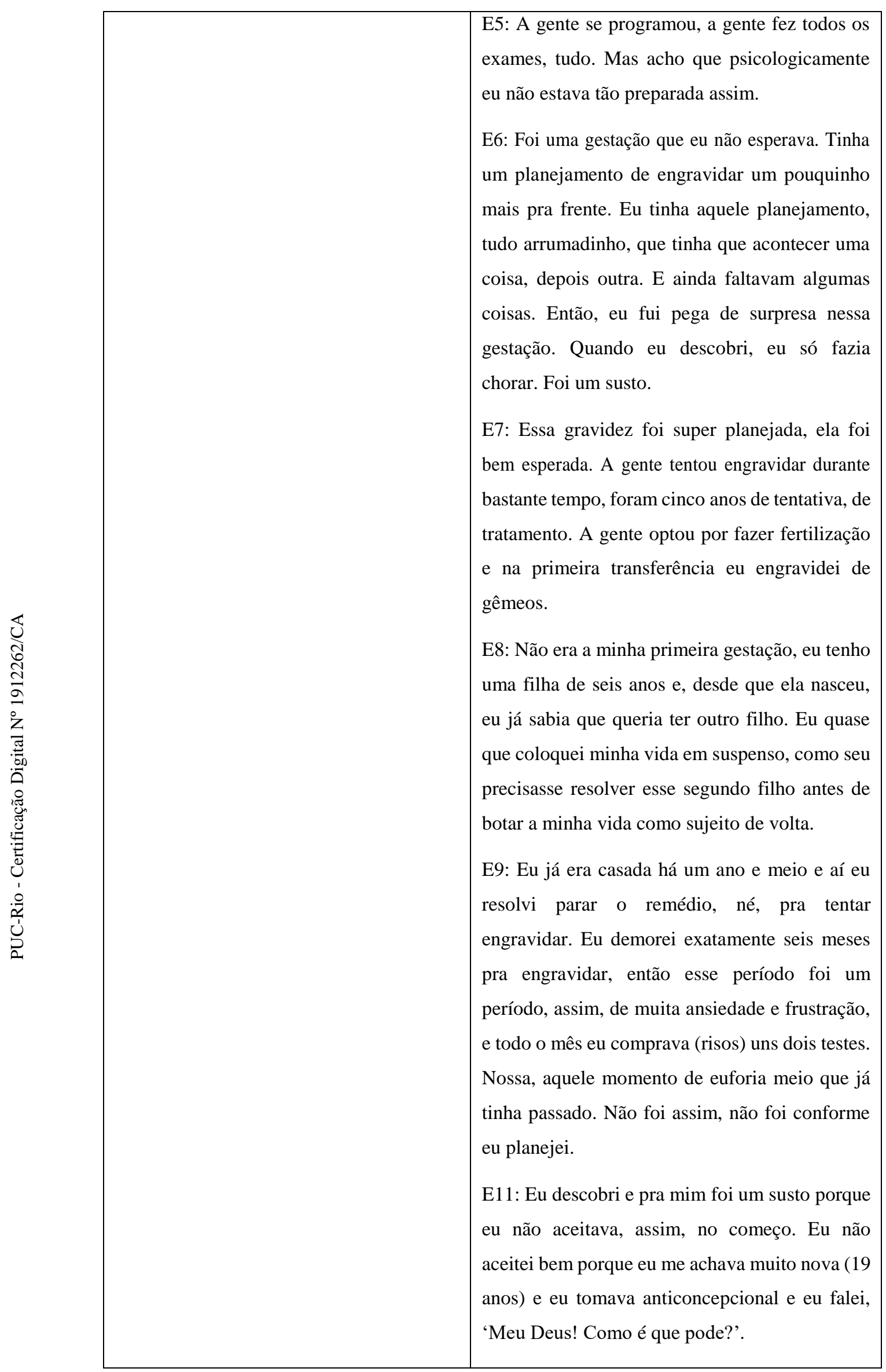




\begin{tabular}{|c|c|c|}
\hline & & $\begin{array}{l}\text { E12: Foi super planejado, a gente tentou } \\
\text { engravidar, a gente ficou um ano tentando } \\
\text { engravidar. } \\
\text { E14: (...) era muito desejado. Seria o primeiro } \\
\text { neto pra ambas as partes. } \\
\text { E15: Foi uma gravidez planejada, planejada } \\
\text { assim, aquela coisa, "vamos engravidar? } \\
\text { Vamos!". Daí parei de tomar a pílula e a gente } \\
\text { meio que deixou rolar assim. } \\
\text { E16: foi uma gravidez planejada, sempre } \\
\text { sonhada. } \\
\text { E17: A gente debateu o tema (engravidar) na } \\
\text { relação, mas logo ele topou, assim. }\end{array}$ \\
\hline 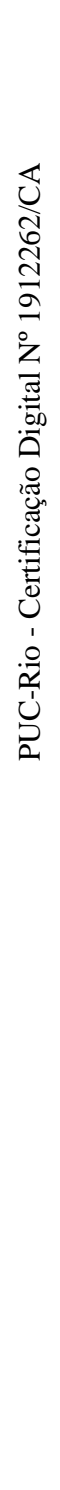 & Compartilhar a notícia da gravidez & $\begin{array}{l}\text { E1: Devia ser por volta de nove semanas mesmo, } \\
\text { que a gente não sabia de nada, né. E nós } \\
\text { contamos pros familiares próximos. } \\
\text { E2: A gente não contou pra ninguém. Nada a } \\
\text { gente contava, tudo nosso era em segredo. Tudo } \\
\text { nosso era só nós dois. } \\
\text { E4: Eu contei mais assim, pra minha família, } \\
\text { mais assim, meus pais, meus sogros. Não fiz um } \\
\text { alarde muito grande. Eu tinha aquela coisa de } \\
\text { contar depois dos três meses, né, de ser uma } \\
\text { coisa mais concreta, né, passar esse período que } \\
\text { é provável... Que se pode acontecer essa perda. } \\
\text { E5: Contei pra todo mundo, coloquei em } \\
\text { Facebook, botei em tudo quanto é lugar. } \\
\text { E6: Eu ia para a casa dos meus pais, eles } \\
\text { terminaram sabendo, a gente terminou contando } \\
\text { porque eu tava ainda super mobilizada. } \\
\text { E6: O meu marido queria dizer pra todo mundo } \\
\text { que a gente estava grávido. } \\
\text { E7: Meus pais ficaram sabendo, alguns amigos } \\
\text { ampla e outras pessoas não. Eu só contei mesmo, } \\
\text { é tailo, quando acha que está tudo certo, que tá }\end{array}$ \\
\hline
\end{tabular}




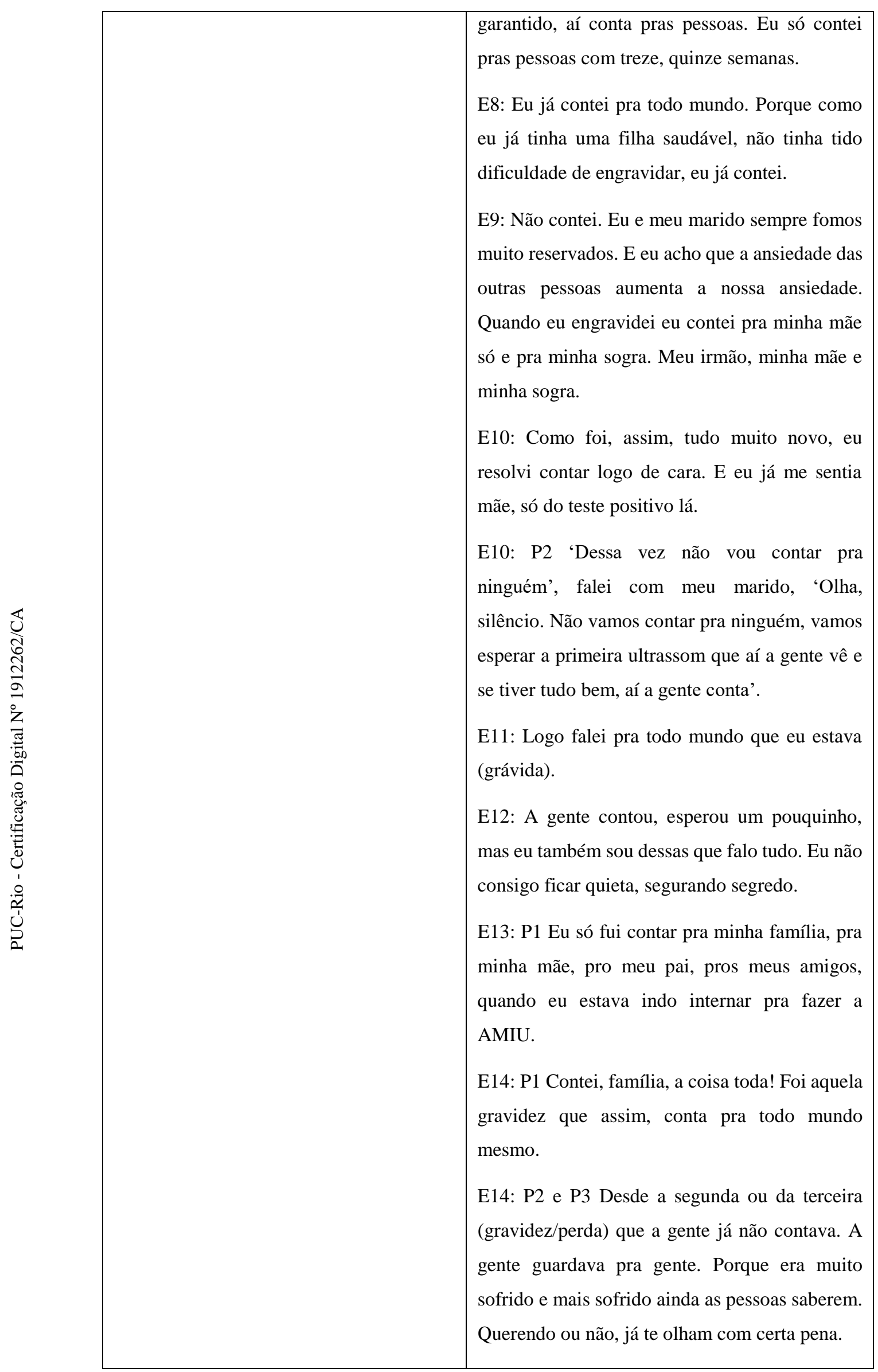




\begin{tabular}{|c|c|}
\hline & $\begin{array}{l}\text { E15: Contei, esperei aqueles três meses, os } \\
\text { exames iniciais, esperei os três meses e aí, tipo } \\
\text { assim, Facebook, 'Estou grávida', conto para o } \\
\text { mundo, né? }\end{array}$ \\
\hline Notícia da perda & $\begin{array}{l}\text { E1: Infelizmente a gente viu lá na hora que o feto } \\
\text { não tava mais com batimentos cardíacos, e aí foi } \\
\text { bem na ultra que a gente descobriu. Não teve } \\
\text { sangramento e de repente aconteceu. } \\
\text { E2: Com sete semanas eu perdi de novo. Eu fui } \\
\text { pra uma consulta para ver como tava o } \\
\text { desenvolvimento do bebê e aí ele falou 'ah, o } \\
\text { coração não tá batendo'. } \\
\text { E3: Quando ele botou o aparelho de } \\
\text { ultrassonografia na minha barriga não ouvi } \\
\text { batimento cardíaco. 'Liga a máquina que a } \\
\text { máquina não tá ligada!' Ele, 'não, a máquina tá } \\
\text { ligada, eu vou ligar pro obstetra'. } \\
\text { E4: Quando eu perdi a primeira vez, a minha } \\
\text { ginecologista na época falou, 'é muito comum } \\
\text { acontecer da primeira gestação perder'. E aí ok. } \\
\text { Ok entre aspas. } \\
\text { E4: Eu tive um sangramento, aí eu fui fazer um } \\
\text { ultrassom para confirmar que tinha havido a } \\
\text { perda. Não cheguei a ouvir os batimentos. } \\
\text { E5: A gente descobriu uma má formação na } \\
\text { bexiga. A gente saiu da clínica no baque, da } \\
\text { questão da má formação e tudo mais. Ficamos de } \\
\text { voltar duas semanas depois pra ver como é que... } \\
\text { Chegamos lá e o bebê tava morto. } \\
\text { achava que estava tudo bem, não tinha tido } \\
\text { E6: A gente fez uma surpresa pro meu pai, ele } \\
\text { tava trabalhando em um hospital, ele dá plantão } \\
\text { em hospital público. O médico que tava fazendo } \\
\text { a ultrassom não conseguiu falar, ele só conseguia } \\
\text { olhar pro meu pai. Meu pai foi quem me disse } \\
\text { que sentia mus que não tinha batimento. } \\
\text { E7to aquele mal estar e até então eu }\end{array}$ \\
\hline
\end{tabular}




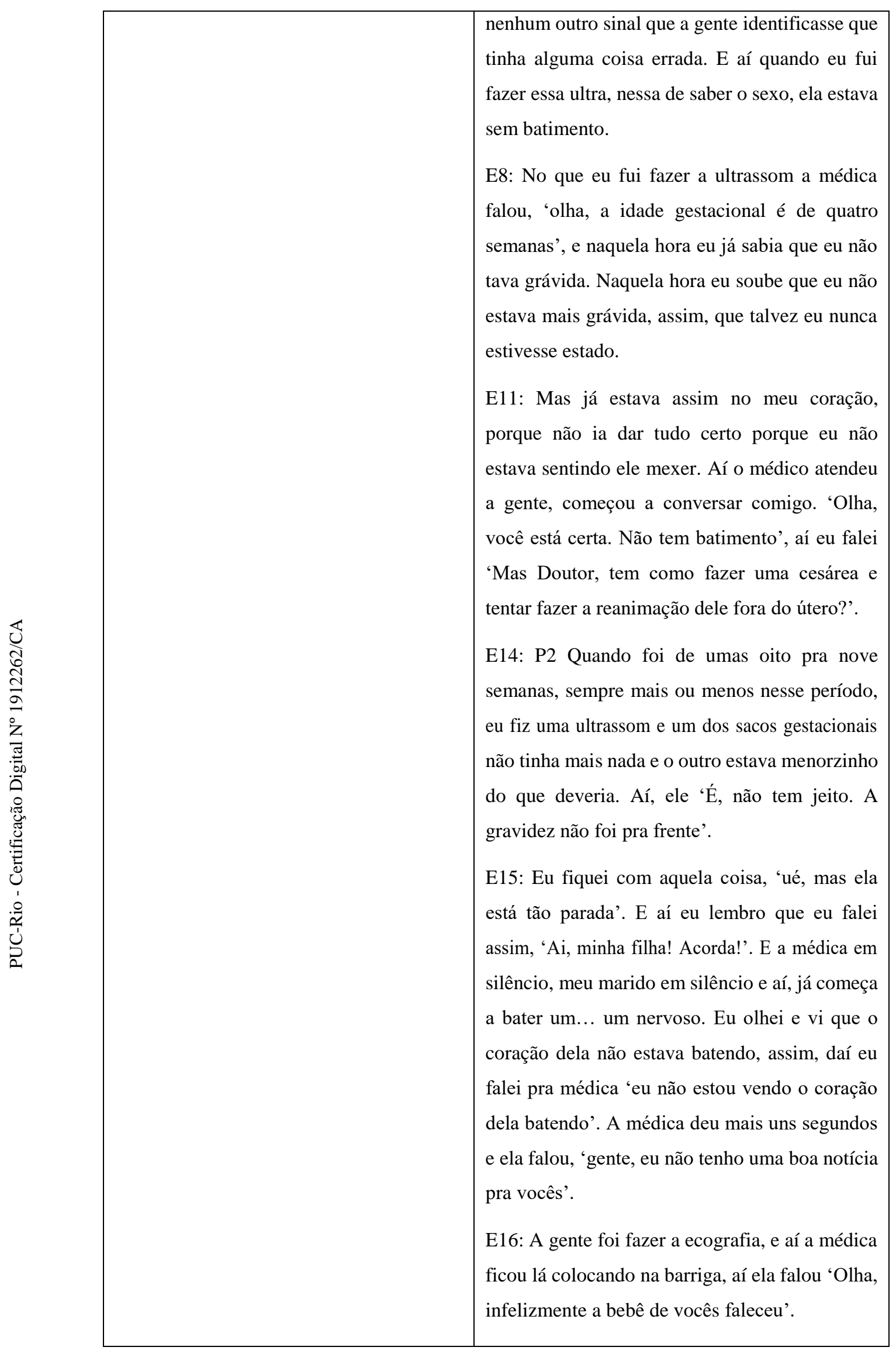




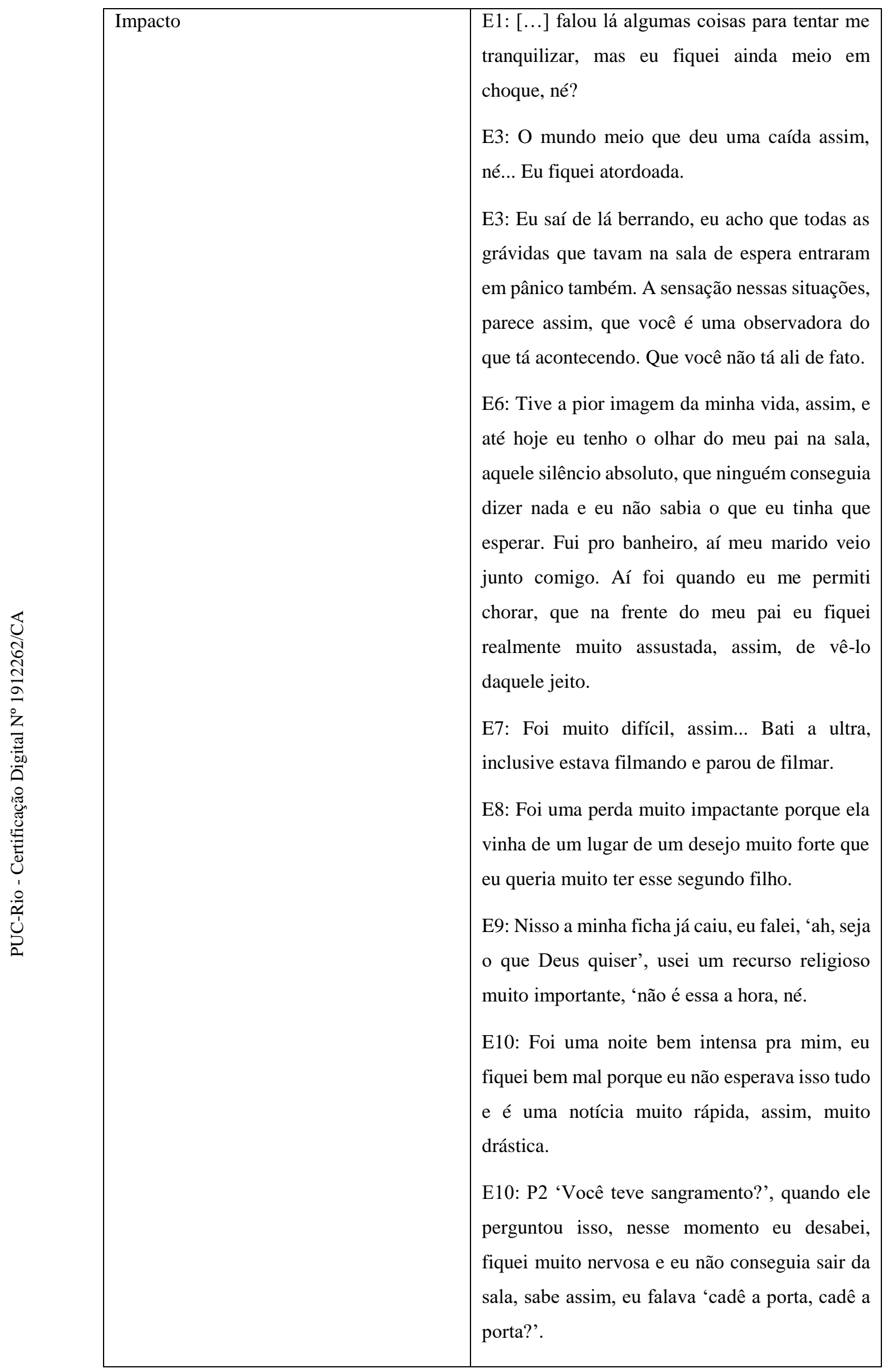




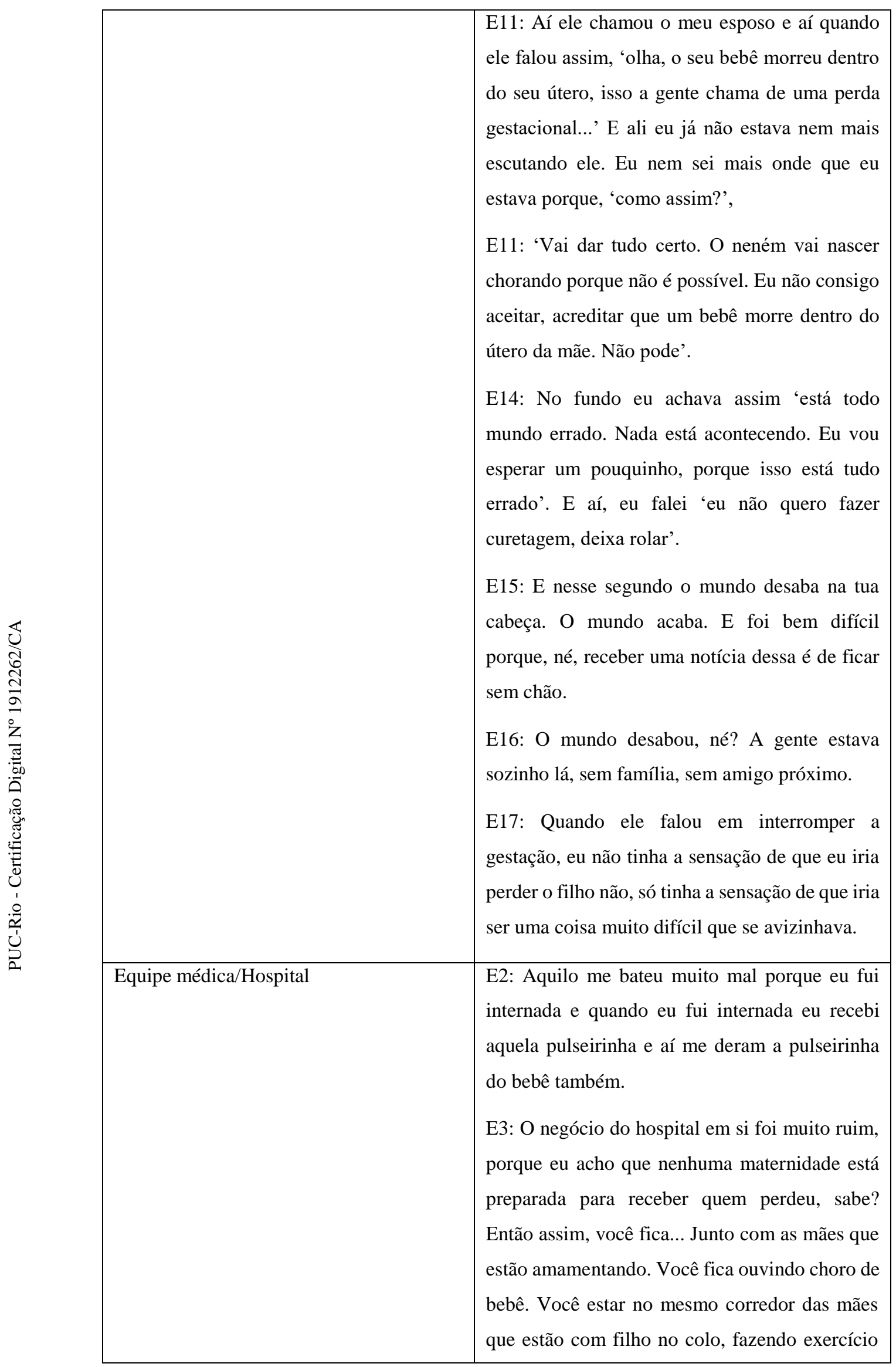




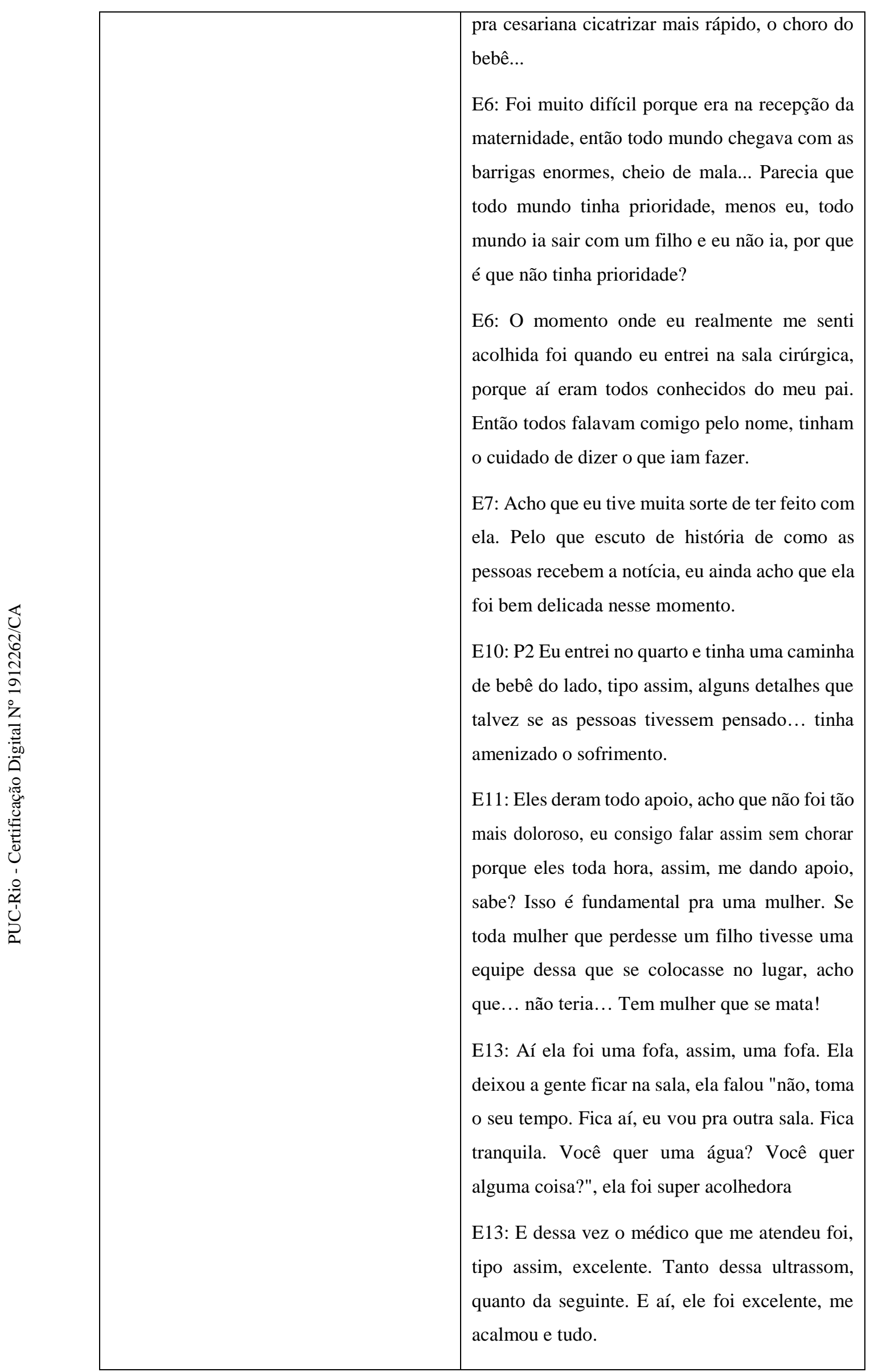




\begin{tabular}{|c|c|}
\hline & $\begin{array}{l}\text { E16: Quando o nosso médico chegou, a gente } \\
\text { estava abraçado e chorando, aí o médico abraçou } \\
\text { a gente e começou a chorar junto com a gente, eu } \\
\text { achei que foi muito acolhedor, sabe, a equipe } \\
\text { toda foi muito acolhedora }\end{array}$ \\
\hline Procedimentos & 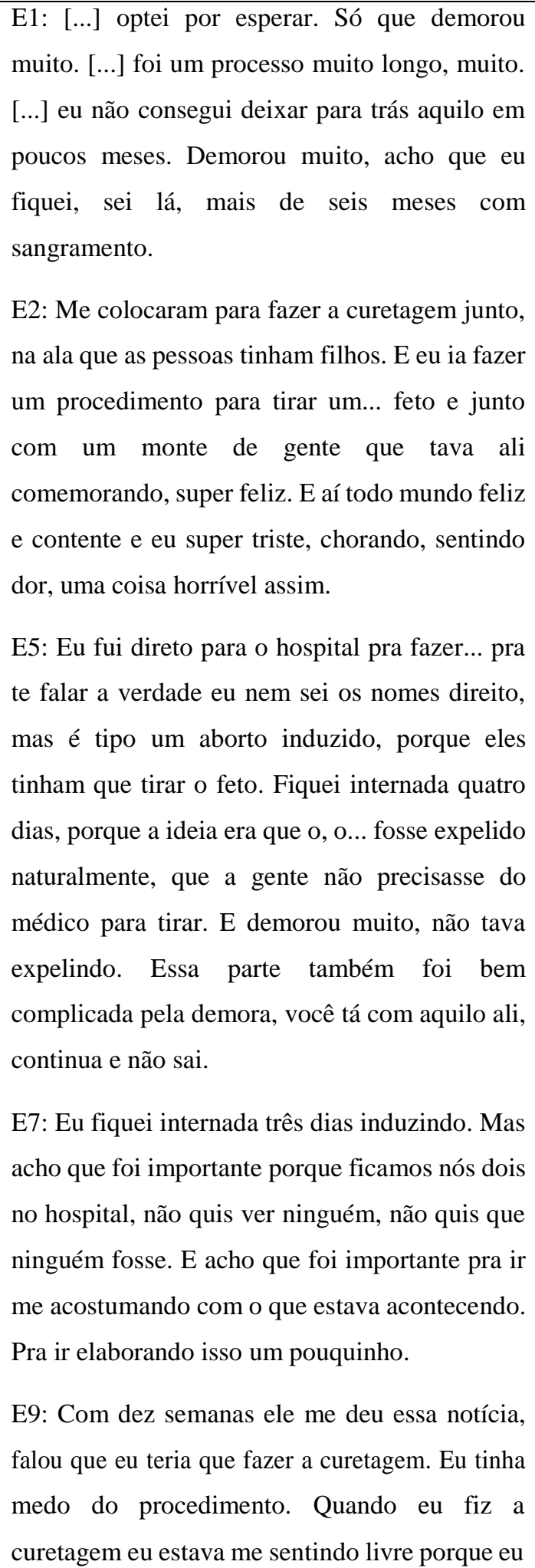 \\
\hline
\end{tabular}




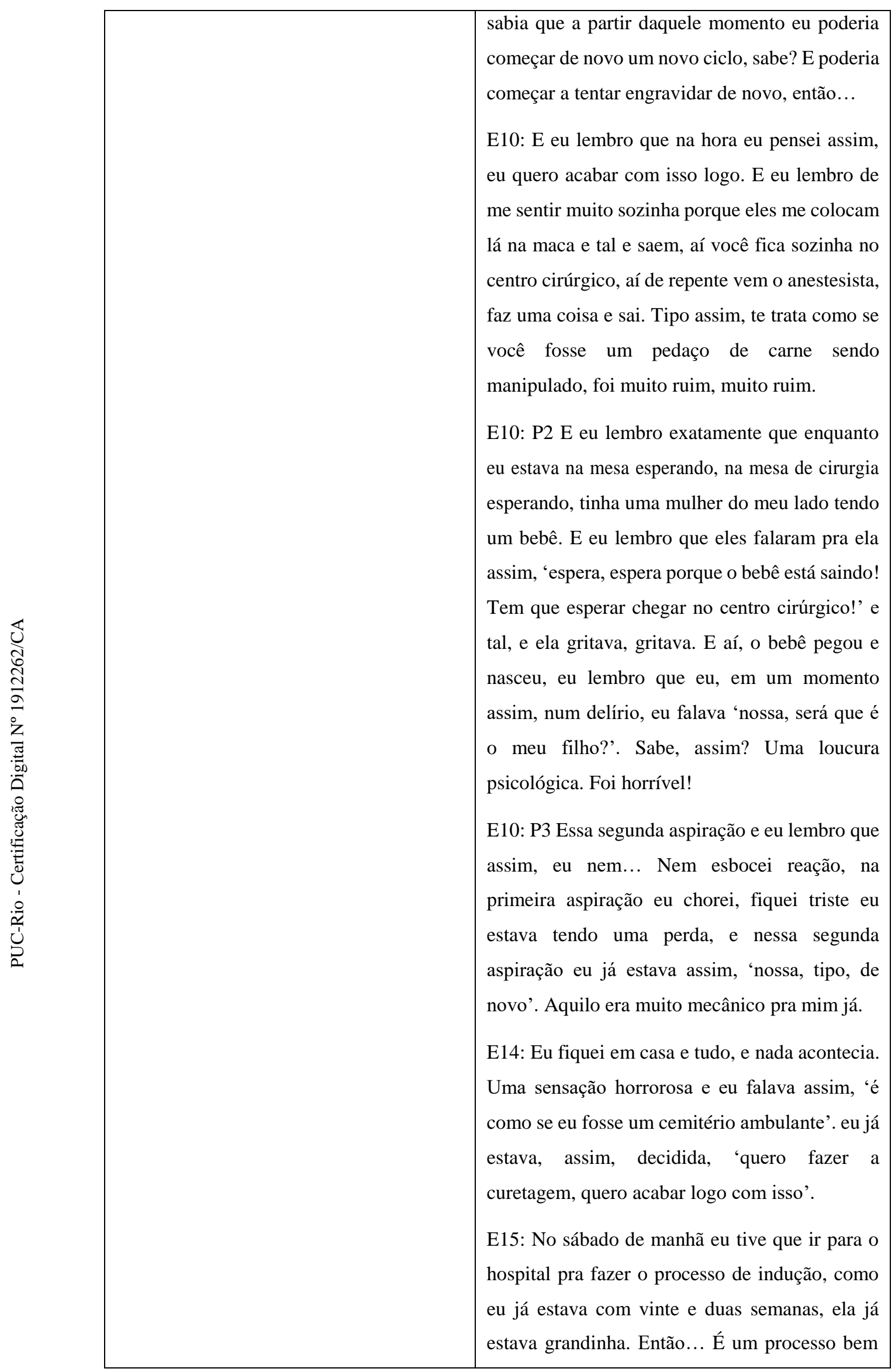




\begin{tabular}{|c|c|}
\hline & $\begin{array}{l}\text { dolorido, assim, dolorido fisicamente } \\
\text { emocionalmente. } \\
\text { E16: Antes da perda, eu já tinha muito medo do } \\
\text { parto normal. Receio da dor, de toda a situação. } \\
\text { Aí, eu falei pra ele 'eu não dou conta. Eu não } \\
\text { consigo. Eu não vou conseguir fazer um parto e } \\
\text { passar por todo esse processo. Eu estou muito } \\
\text { abalada, eu não estou conseguindo nem respirar, } \\
\text { quanto mais ter um parto agora. Não vou } \\
\text { conseguir'. Aí, ele falou 'Então tá. Então, a gente } \\
\text { faz a cesariana. Mas você sabe que com a } \\
\text { cesariana você vai demorar mais tempo pra ter } \\
\text { outro filho, vai ter que se recuperar', A última } \\
\text { coisa que eu estava pensando era ter um filho. } \\
\text { E16: O médico me perguntou se eu queria estar } \\
\text { acordada ou se eu queria tomar um remédio pra } \\
\text { dormir, aí eu falei que não, que eu queria estar } \\
\text { acordada e ter um momento com ela porque eu } \\
\text { precisava acreditar } \\
\text { acontecendo. } \\
\text { assim, tira ele daqui (risos) e leva ele pra } \\
\text { ele, ele veio pra mim mas eu mesma estava } \\
\text { assim, 'Cara, eu quero que ele respire. Então } \\
\text { andoras }\end{array}$ \\
\hline Ver o bebê & $\begin{array}{l}\text { E3: Eu tava muito nervosa e tal e eu optei por } \\
\text { não ver. Eu acho que eu não deixei nem me } \\
\text { perguntar. Eu falei que não queria ver. Acho que } \\
\text { aquela imagem ia ser, ia ser difícil assim... Um } \\
\text { neném morto é uma coisa surreal, mesmo não } \\
\text { sendo nosso. } \\
\text { E7: Eu vi. Eu não tive muita opção, né. Porque } \\
\text { como foi indução eu vi na hora que elas saíram. } \\
\text { Não parei para ficar olhando. Foi um momento } \\
\text { muito tumultuado, eu tava com muita dor. Mas } \\
\text { eu consegui ver as duas. } \\
\text { E11: Eu olhei ele, olhei pra ele, olhei pra meu } \\
\text { esposo e a menina já estava preparada pra levar }\end{array}$ \\
\hline
\end{tabular}




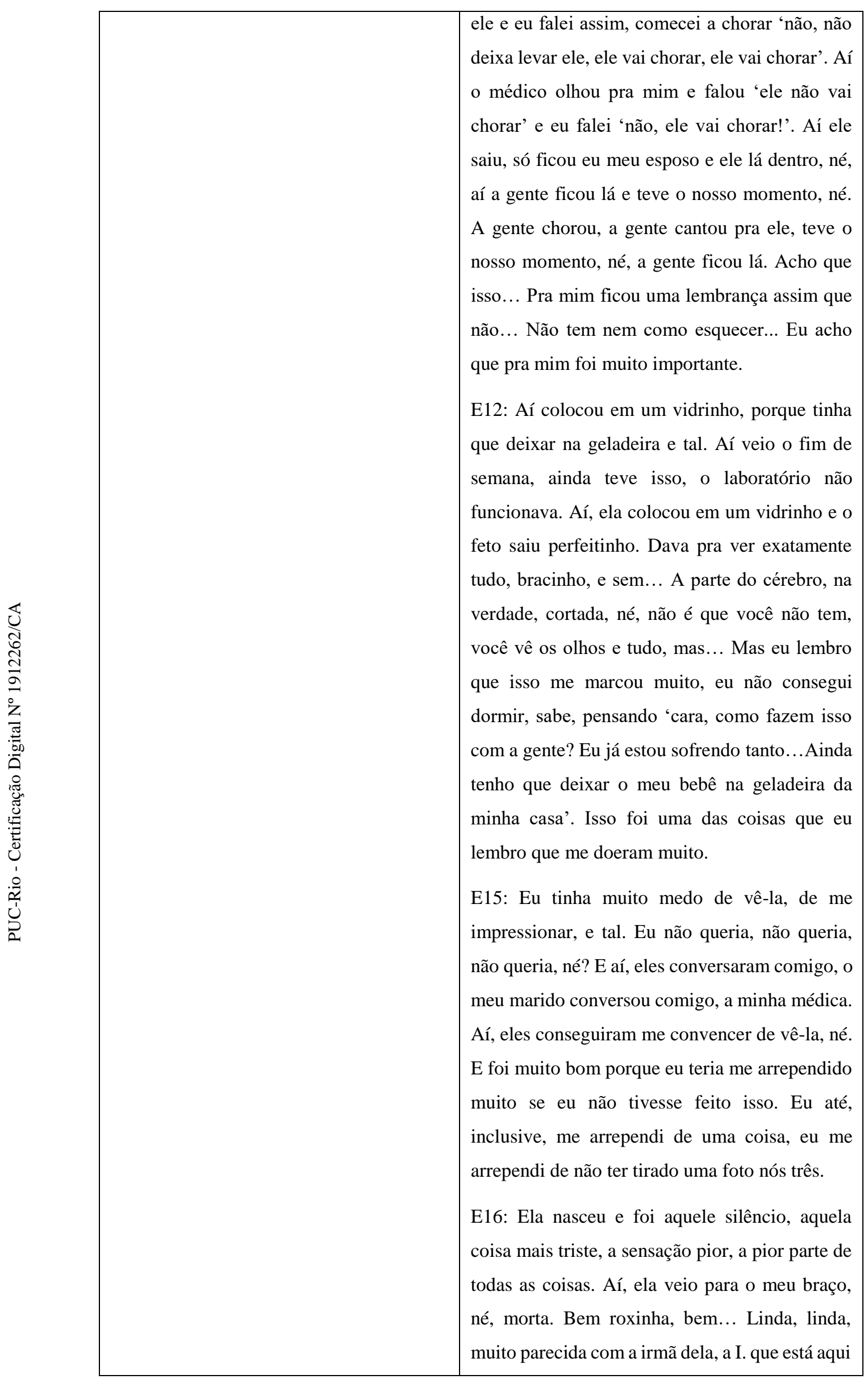




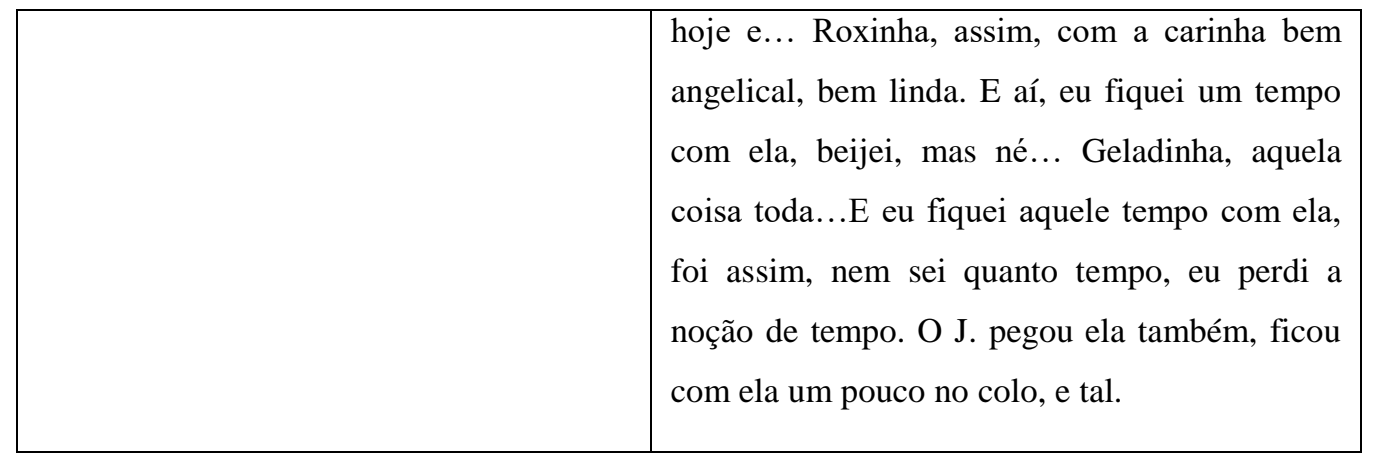

Nas respostas à primeira questão, relacionada à experiência da perda, foram identificadas 7 categorias. A maioria das mães relatou que a gravidez foi muito planejada e que era um desejo tanto delas quanto do marido. Uma das mães referiu que "A gente se programou, a gente fez todos os exames, tudo. Mas acho que psicologicamente eu não estava tão preparada assim" (E5), revelando que, retrospectivamente, percebeu que não estava emocionalmente preparada para a gestação o que, de alguma forma, afetou a forma de vivenciar essa perda. Apenas uma das mães conta que a gravidez interrompida não foi planejada "Eu descobri e pra mim foi um susto porque eu não aceitava, assim, no começo. Eu não aceitei bem porque eu me achava muito nova (19 anos) e eu tomava anticoncepcional e eu falei, 'Meu Deus! Como é que pode?'” (E11)

Foi possível perceber que as mães buscaram explicar detalhadamente o processo desde o desejo de engravidar, os preparativos para a chegada desse bebê, a forma como compartilharam a notícia de que estavam grávidas e, especialmente, dedicaram-se em descrever detalhes sobre a história da perda e os procedimentos de retirada do bebê morto. Apenas uma das entrevistadas (E17) teve um bebê que nasceu vivo e faleceu dois dias depois.

Segundo Neimeyer (1999), a partir da teoria construtivista, a perda é vista como um acontecimento que pode perturbar profundamente a vida de uma pessoa e suas construções de vida tidas como certas, garantidas. Além disso, perdas também são capazes de abalar o mundo presumido, conceito de Parkes (2009) que caracteriza o que é dado como certo e garantido em nossas vidas. A partir do impacto da perda, as concepções sobre si mesmo e sobre o mundo são modificadas, assim como há transformações nas estratégias de enfrentamento da vida e de seus acontecimentos. A partir do questionamento sobre como aconteceu a perda, as mães construíram uma narrativa detalhada sobre a forma aconteceu, relatando os fatos 
em ordem cronológica para tentar trazer algum sentido para o ocorrido. De acordo com Neimeyer, Klass e Dennis (2014), construir narrativas sobre as experiências de vida é um processo intrinsicamente humano, como uma forma de construção de sentido. Para os autores, não é surpresa que perdas e luto estejam tão conectados à busca e construção de significados.

Em relação ao primeiro impacto frente a notícia de que a perda tinha acontecido, foram descritas reações de choque e descrença. "Eu fiquei ainda meio em choque, né?’ (E1) “O mundo meio que deu uma caída assim, né... Eu fiquei atordoada" (E3). "E ali eu já não estava nem mais escutando ele. Eu nem sei mais onde que eu estava porque, ‘como assim'?” (E11), “A sensação nessas situações, parece assim, que você é uma observadora do que tá acontecendo. Que você não tá ali de fato" (E3). "No fundo eu achava assim, está todo mundo errado. Nada está acontecendo. Eu vou esperar um pouquinho, porque isso está tudo errado” (E14). As reações descritas pelas entrevistas estão em concordância com uma das respostas de luto apontadas por Bowlby (2004), que descreve o entorpecimento como o primeiro estágio do luto, caracterizado por choque, torpor e descrença. Para o autor, o entorpecimento tem uma função protetora, uma vez que fornece à pessoa um tempo a mais para assimilar o impacto da perda. Mesmo não compreendendo o luto como um processo dividido em fases ou estágios, é possível perceber que existem reações que podem ser comuns e que fazem parte do processo de luto propriamente dito. Se, por um lado Worden (2013) afirma que o processo de luto tem início com a aceitação da realidade da perda, parece haver um momento anterior, que faz parte do luto, em que ainda não parece ser possível realizar a perda.

Uma questão importante trazida por seis mães, especialmente as que tiveram perdas tardias, foi relacionada ao fato de ver ou não o bebê morto. E3, que descobriu a perda na $38^{\mathrm{a}}$ semana de gestação de uma forma inesperada, optou por não ver e sente que sequer deixou que a equipe de saúde lhe desse a opção. "Eu tava muito nervosa e tal e eu optei por não ver. Eu acho que eu não deixei nem me perguntar. Eu falei que não queria ver. Acho que aquela imagem ia ser, ia ser difícil assim... Um neném morto é uma coisa surreal, mesmo não sendo nosso". Salgado e Polido (2018) destacam que quando não há tempo para se preparar para a chegada do bebê, é comum que as famílias rejeitem esse contato. Hughes et al (2002) identificaram que as mulheres que não viam os bebês mortos tinham menos risco de complicação do processo de luto. Entretanto, para as mães que optaram por ver os seus bebês 
esse momento foi descrito como muito significativo e E15 destaca a importância do suporte da médica e do marido nessa decisão. "Eu tinha muito medo de vê-la, de me impressionar, e tal. Eu não queria, não queria, não queria, né? E aí, eles conversaram comigo, o meu marido conversou comigo, a minha médica. Aí, eles conseguiram me convencer de vê-la, né. E foi muito bom porque eu teria me arrependido muito se eu não tivesse feito isso". De acordo com Üstündağ-Budak et al (2015), muito se tem feito, atualmente, para ajudar os pais a criarem e guardarem memórias com o filho (a), sendo ver e segurar o bebê morto uma dessas ações. Eles afirmam que é muito importante para o processo de luto ter esse momento com o bebê. E16 descreve com detalhes a cena de segurar sua filha no colo. "Ela nasceu e foi aquele silêncio, aquela coisa mais triste, a sensação pior, a pior parte de todas as coisas. Aí, ela veio para o meu braço, né, morta. Bem roxinha, bem... Linda, linda, muito parecida com a irmã dela, que está aqui hoje e... Roxinha, assim, com a carinha bem angelical, bem linda. E aí, eu fiquei um tempo com ela, beijei, mas né... Geladinha, aquela coisa toda...E eu fiquei aquele tempo com ela, foi assim, nem sei quanto tempo, eu perdi a noção de tempo. O J (marido) pegou ela também, ficou com ela um pouco no colo".

Em relação à equipe médica e ao hospital, algumas mães referiram dificuldade em não se sentirem acolhidas e respeitadas em suas dores, especialmente no que diz respeito ao fato de terem perdido seus bebês próximas a mulheres que estavam tendo seus filhos vivos. "O negócio do hospital em si foi muito ruim, porque eu acho que nenhuma maternidade está preparada para receber quem perdeu, sabe? Então assim, você fica... Junto com as mães que estão amamentando. Você fica ouvindo choro de bebê." (E3). "Aquilo me bateu muito mal porque eu fui internada e quando eu fui internada eu recebi aquela pulseirinha e aí me deram a pulseirinha do bebê também” (E2). Salgado e Polido (2018) destacam a necessidade do treinamento homogêneo e coletivo da equipe da instituição, uma vez que é necessário que todos sejam capazes de oferecer cuidado empático e suportivo para a família enlutada. E6 destaca a falta de acolhimento que sentiu já na recepção da maternidade. "Foi muito difícil porque era na recepção da maternidade, então todo mundo chegava com as barrigas enormes, cheio de mala... Parecia que todo mundo tinha prioridade, menos eu, todo mundo ia sair com um filho e eu não ia, por que é que não tinha prioridade?". Protocolos bem estruturados são fundamentais quando ocorrem perdas dentro de uma maternidade, entretanto é 
importante que também haja flexibilidade e atenção às necessidades de cada família.

\begin{tabular}{|c|c|}
\hline Categorias de Análises - LUTO & Informações obtidas \\
\hline Tempo & $\begin{array}{l}\text { E1: Durou muito sim. } \\
\text { E3: Eu tive sei, lá, uma crise de choro que deve } \\
\text { ter durado um mês, dois meses no máximo. } \\
\text { E7: Eu tive uma recuperação física muito } \\
\text { demorada. Todo esse processo de recuperação } \\
\text { física levou, sei lá, cinco meses assim. Eu acho } \\
\text { que até essa recuperação física ter sido lenta pra } \\
\text { mim também foi importante porque não me } \\
\text { deixou esquecer o que tinha acontecido. } \\
\text { E12: Eu confesso a você, eu não sei nem se foi, } \\
\text { enfim, pensado ou não. Mas eu acho até que ele } \\
\text { foi curto, como uma forma assim, talvez, de... } \\
\text { De defesa e de ir em frente, sabe? } \\
\text { E15: Conforme os dias vão passando o processo } \\
\text { de luto... Não que, eu costumo falar muito } \\
\text { assim, não é que não dói, é que eu acho que a } \\
\text { gente aprende a viver com a dor, sabe? Aí, } \\
\text { chegou uma época que olhar grávida já não me } \\
\text { doía mais tanto, }\end{array}$ \\
\hline Tristeza & $\begin{array}{l}\text { E2: Aí eu fiquei arrasada, só de falar já fico } \\
\text { muito triste. Porque foi muito difícil para mim. } \\
\text { Foi muito, muito, muito triste. Eu lembro como } \\
\text { se fosse hoje, assim. [...] Saí de lá arrasada e fui } \\
\text { trabalhar. } \\
\text { E2: Ah, eu nunca vivi assim. Eu ficava muito } \\
\text { triste, assim, mas eu não me deixava abater } \\
\text { porque não dava tempo, entendeu? Tinha que } \\
\text { correr contra o tempo porque se não eu nunca iria } \\
\text { ser mãe. E eu sempre achava, 'será que eu não } \\
\text { vou conseguir ser mãe?'. } \\
\text { E4: Eu acredito que eu vivenciei esse luto, no } \\
\text { sentindo assim, de acolher a tristeza... a raiva } \\
\text { também. Eu acho que a gente passa por todo esse }\end{array}$ \\
\hline
\end{tabular}




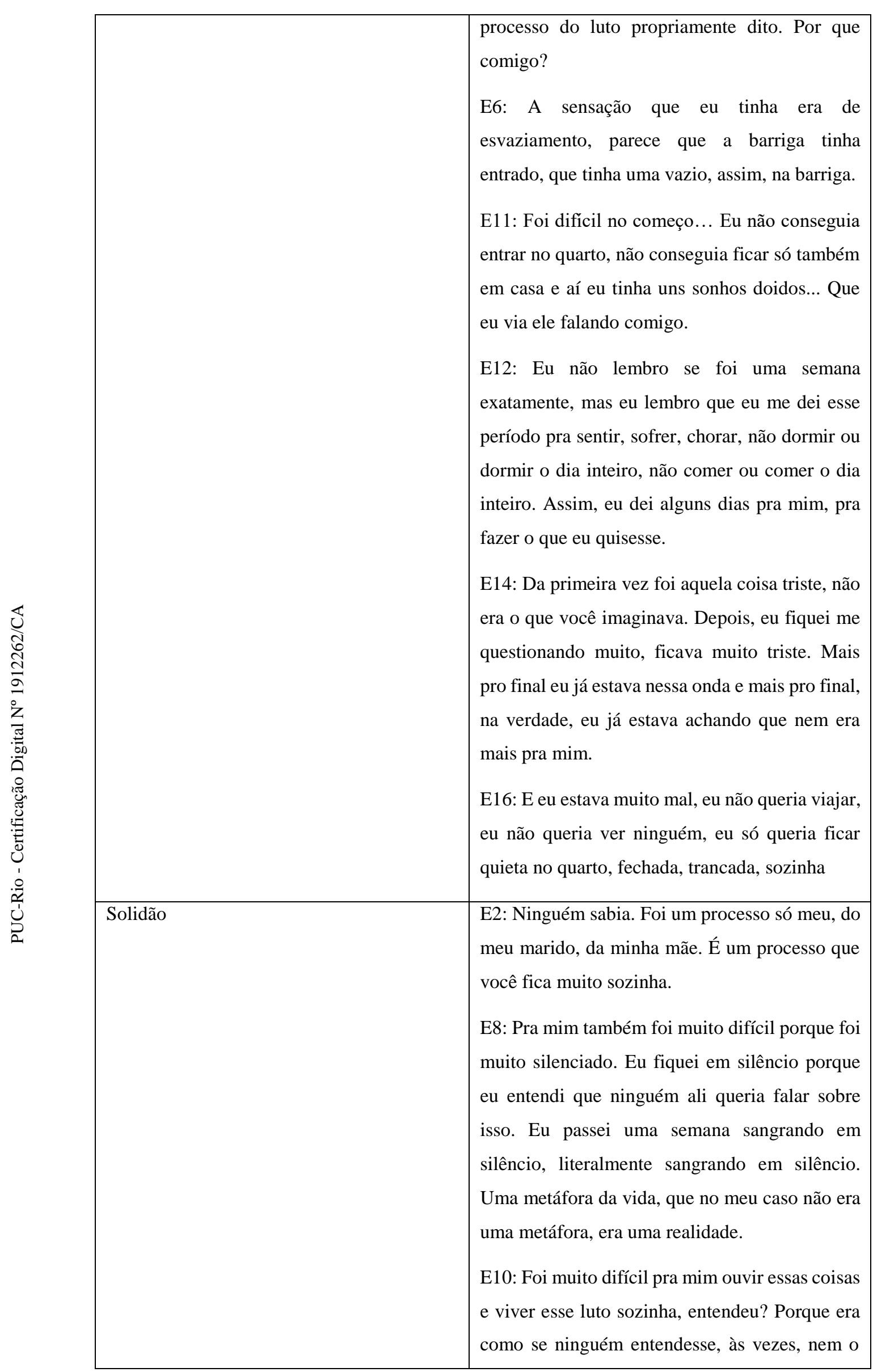




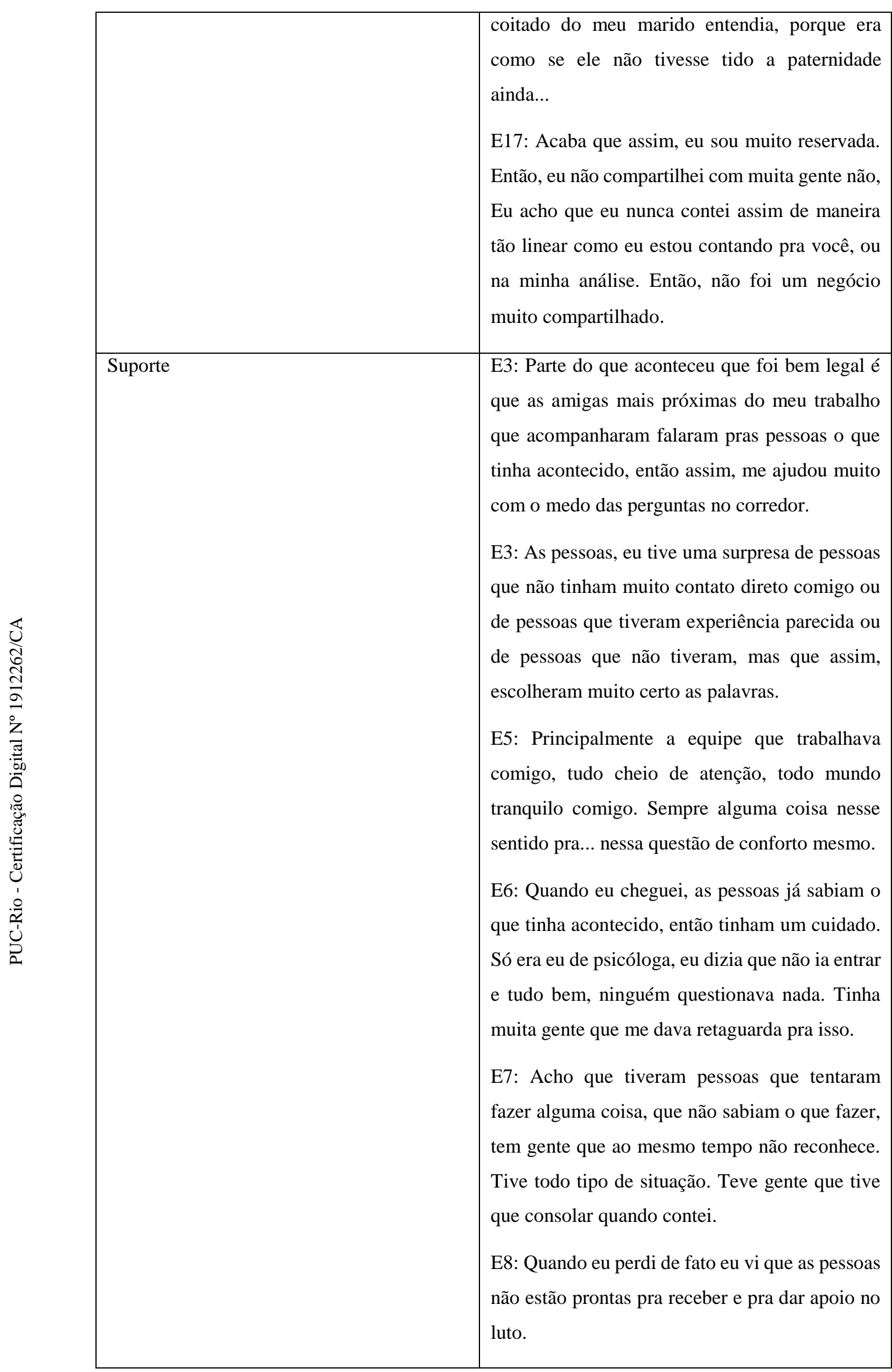




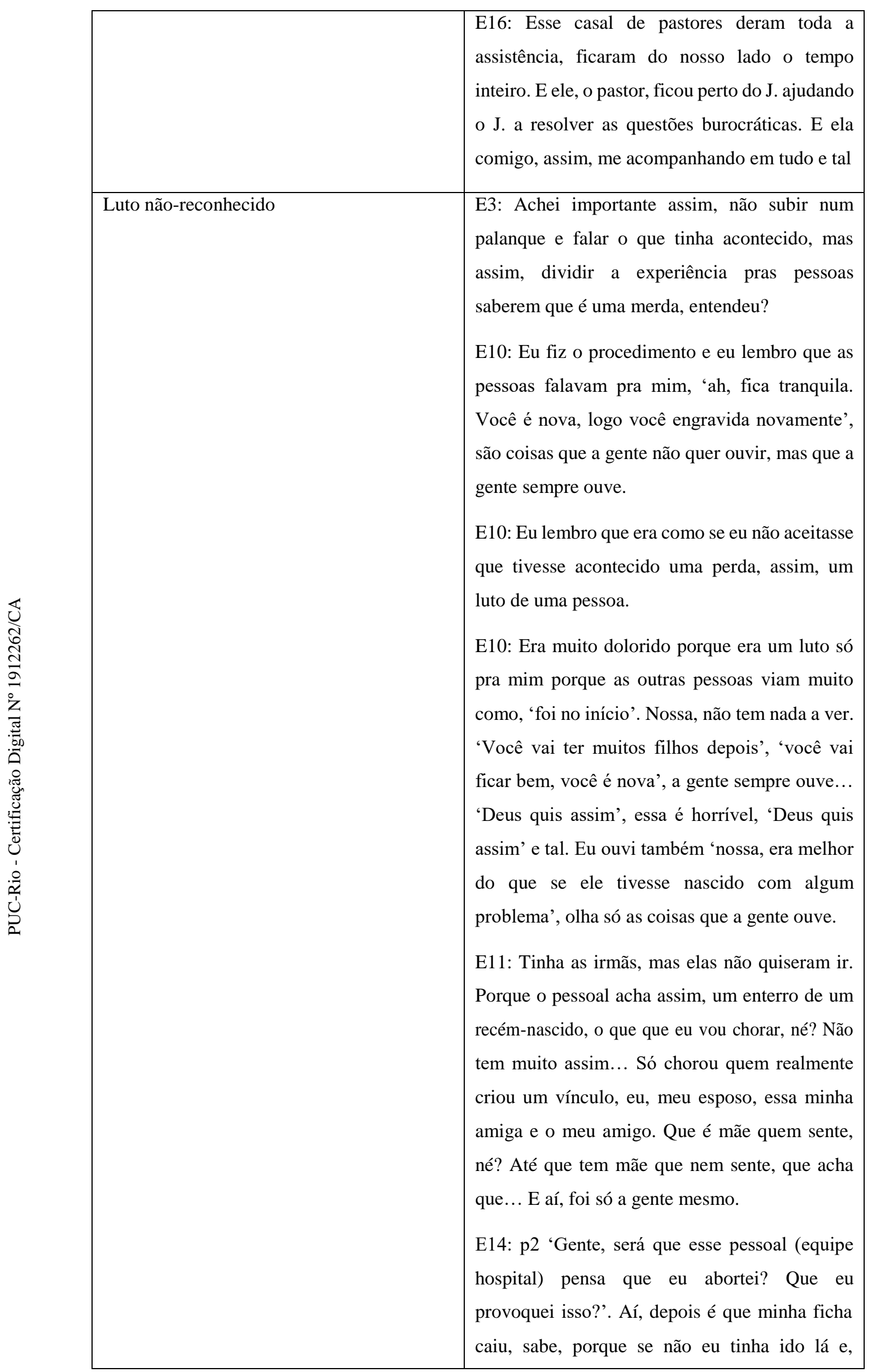




\begin{tabular}{|c|c|}
\hline & $\begin{array}{l}\text { 'Gente, vocês tem ideia que tudo o que eu mais } \\
\text { queria era isso? Que eu estou sofrendo?'. }\end{array}$ \\
\hline Rituais & 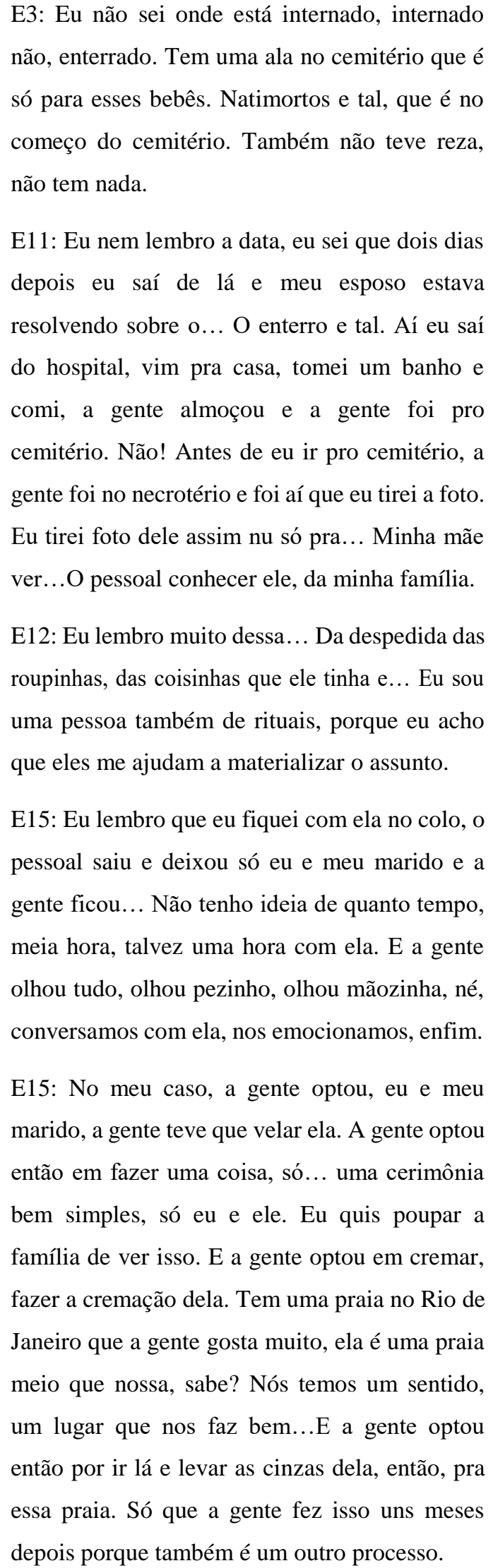 \\
\hline
\end{tabular}




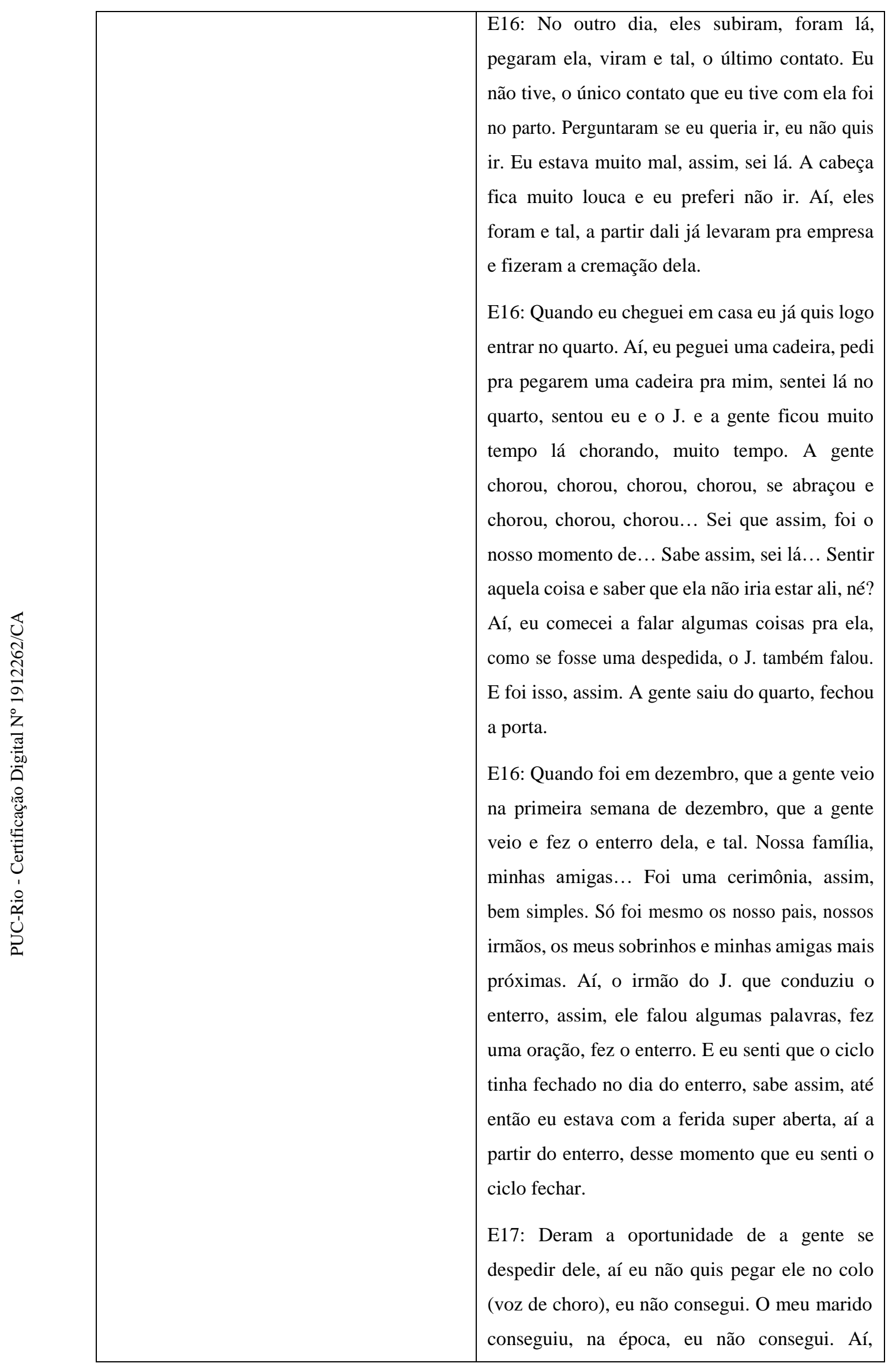




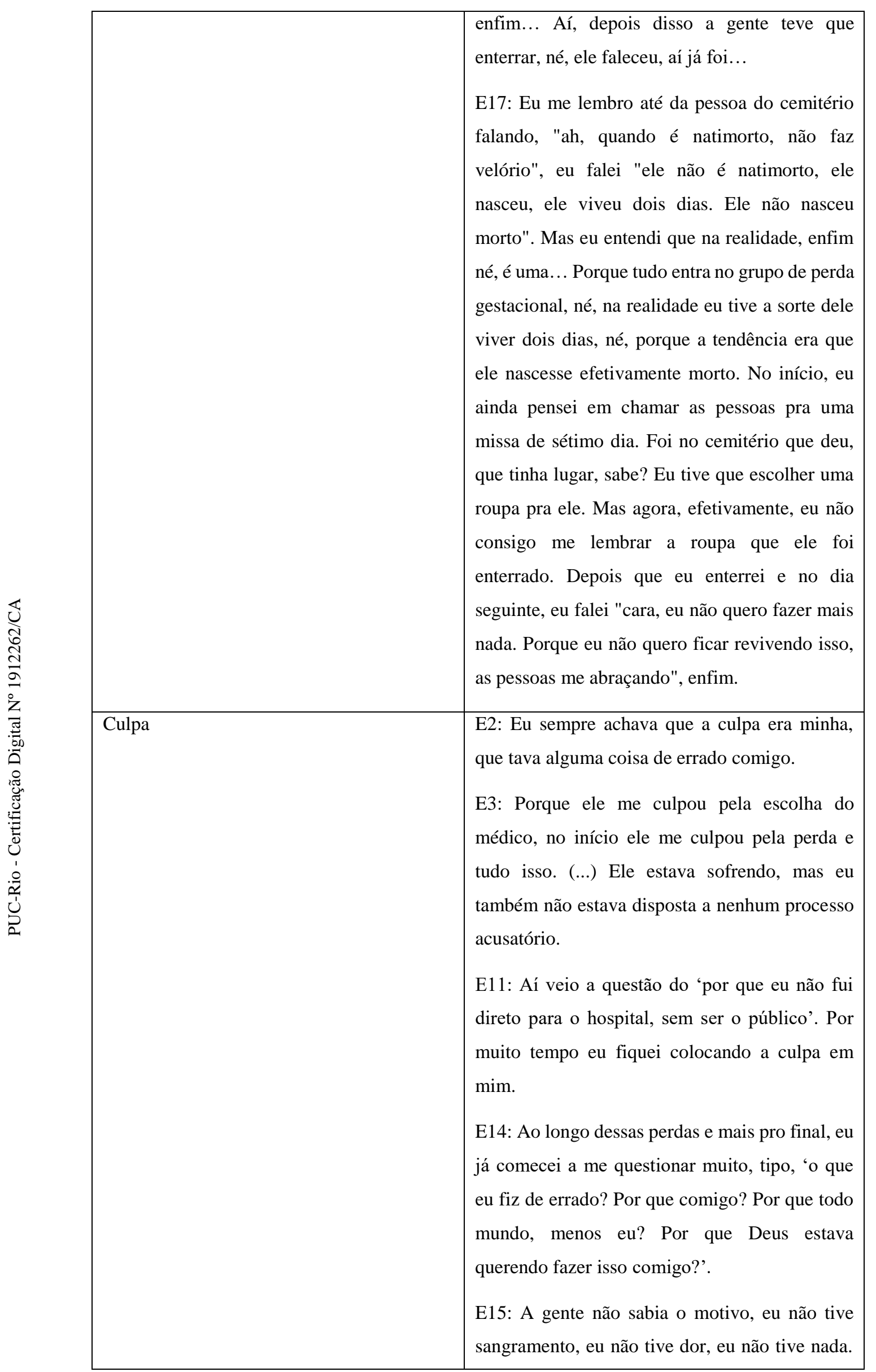




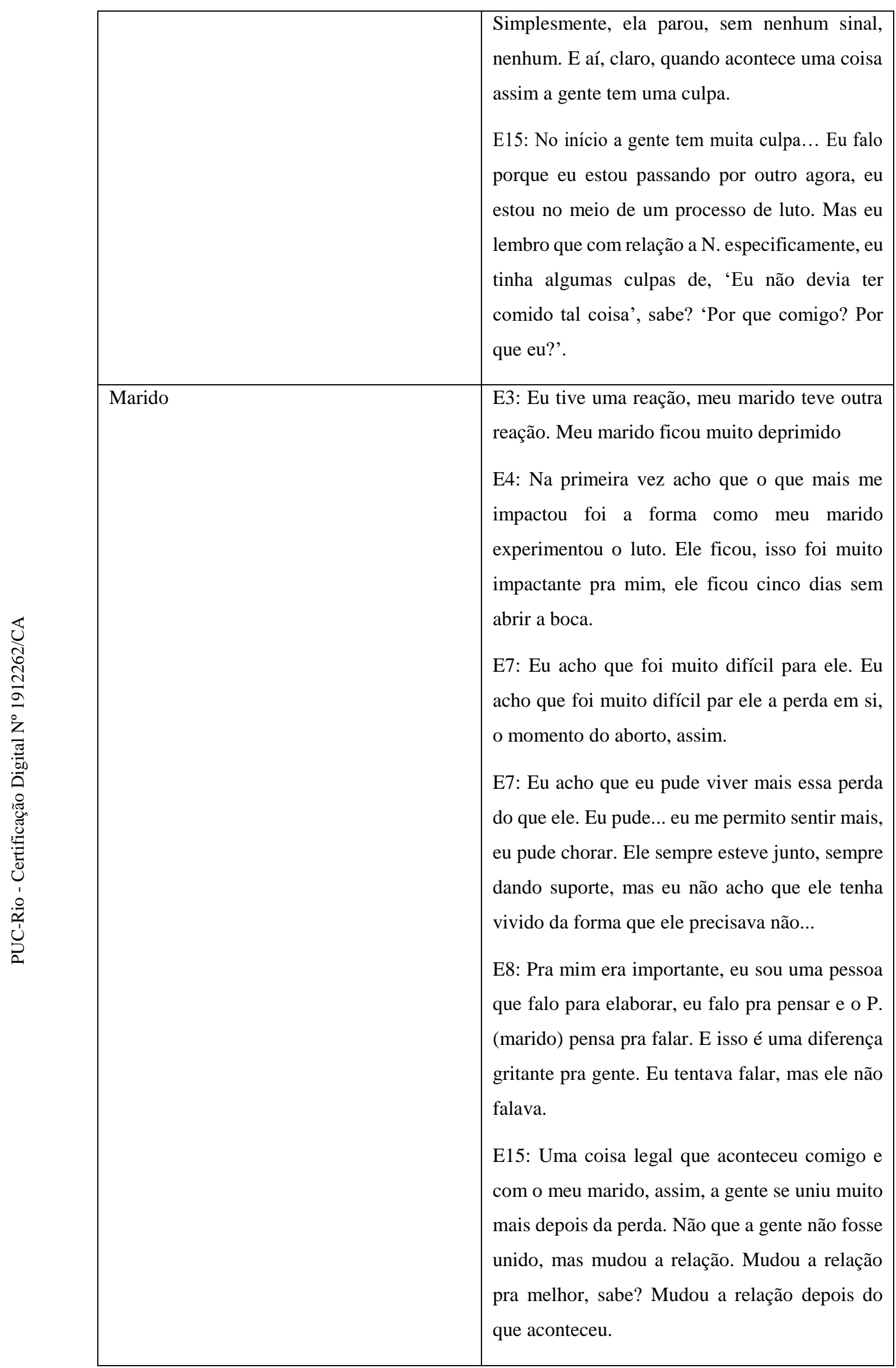




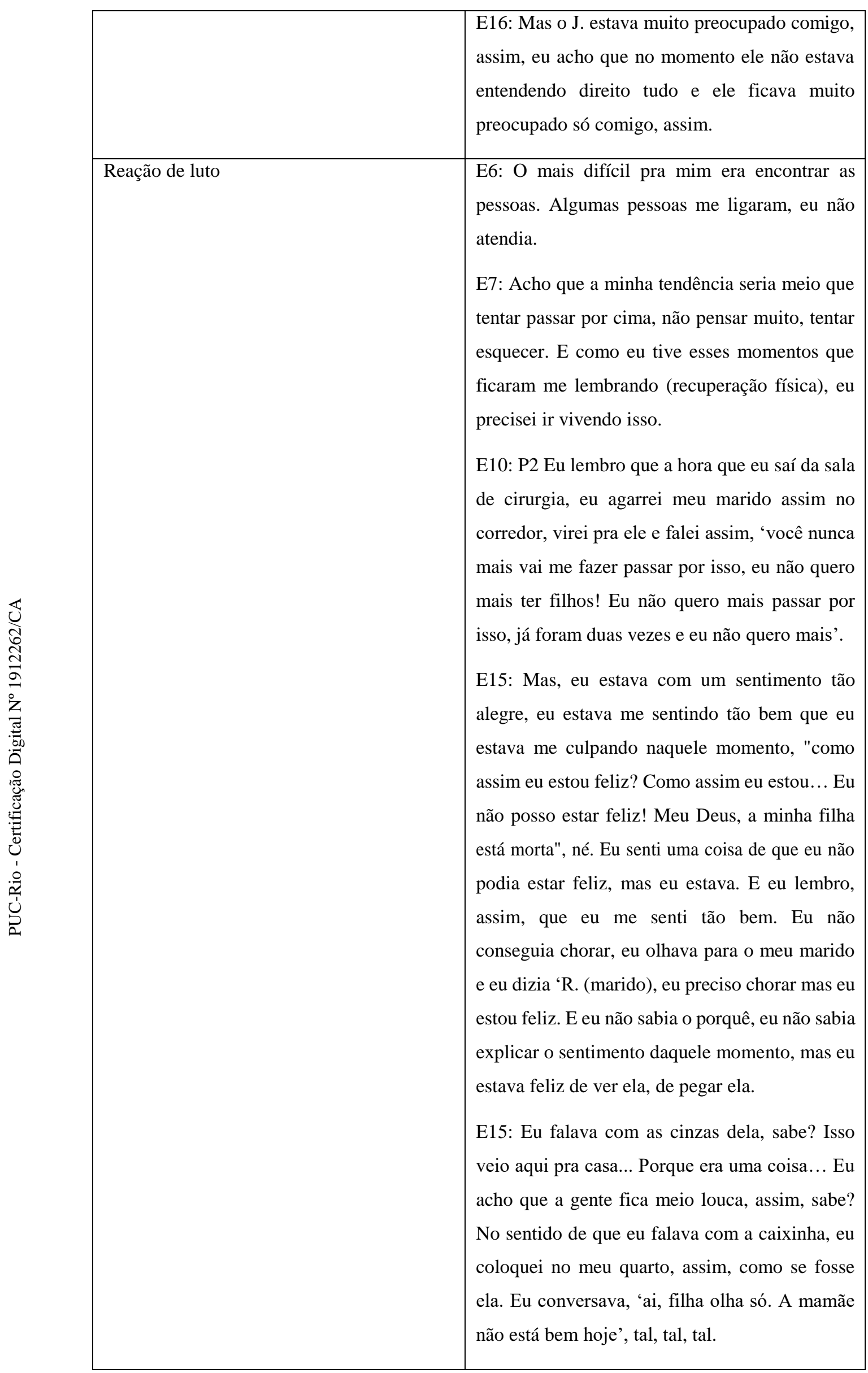




\begin{tabular}{|l|l|}
\hline & $\begin{array}{l}\text { E16: Eu sofri muito, muito, assim. Eu emagreci } \\
\text { dezesseis quilos... em quarenta e cinco dias, por } \\
\text { aí, sabe? Eu não conseguia comer, eu não } \\
\text { conseguia respirar, assim, era uma dor enorme, } \\
\text { enorme que eu sentia, sabe? Eu sentia ânsia de } \\
\text { vômito. Me afastei totalmente de todo mundo. } \\
\text { Eu tentava ainda manter um social, mas as } \\
\text { grávidas eu não tinha contato, não conseguia ver. } \\
\text { Fiquei bem isolada. }\end{array}$ \\
\hline
\end{tabular}

A tristeza foi identificada como categoria, sendo referida como um dos principais sentimentos das mães após uma perda gestacional ou neonatal. Bowlby (2004), identifica a tristeza como uma resposta natural e esperada frente ao luto, sendo esse sentimento incluído dentro do estágio de desorganização e desespero, a partir do momento em que o enlutado percebe que a perda é real. "Da primeira vez foi aquela coisa triste, não era o que você imaginava. Depois, eu fiquei me questionando muito, ficava muito triste. Mais pro final eu já estava nessa onda e mais pro final, na verdade, eu já estava achando que nem era mais pra mim” (E14); "Aí eu fiquei arrasada, só de falar já fico muito triste. Porque foi muito difícil para mim. Foi muito, muito, muito triste. Eu lembro como se fosse hoje, assim" (E2). "E eu estava muito mal, eu não queria viajar, eu não queria ver ninguém, eu só queria ficar quieta no quarto, fechada, trancada, sozinha" (E16).

Worden (2013) identifica como uma das tarefas do luto processar a dor da perda, salientando a necessidade de vivenciar a tristeza e dar espaço para o sofrimento. O autor, entretanto, pontua que a tristeza não é o único sentimento relacionado ao luto, e que raiva, culpa e solidão, entre outros, também precisam ser processados. "Eu acredito que eu vivenciei esse luto, no sentindo assim, de acolher a tristeza... a raiva também. Eu acho que a gente passa por todo esse processo do luto propriamente dito. Por que comigo?" (E4)

E12 abordou a questão do tempo que se permitiu dar espaço para a tristeza, em uma tentativa de controlar os sentimentos ligados à perda "Eu não lembro se foi uma semana exatamente, mas eu lembro que eu me dei esse período pra sentir, sofrer, chorar, não dormir ou dormir o dia inteiro, não comer ou comer o dia inteiro. Assim, eu dei alguns dias pra mim pra fazer o que eu quisesse". 
A culpa é uma reação comum em situações de luto e foi identificada em algumas das entrevistas. Stroebe et al (2014) referem que, ao vivenciarem uma perda significativa, as pessoas costumam pensar no que poderiam ter feito de diferente. "Aí veio a questão do 'por que eu não fui direto para o hospital, sem ser o público'. Por muito tempo eu fiquei colocando a culpa em mim.” (E11); “Ao longo dessas perdas e mais pro final, eu já comecei a me questionar muito, tipo, 'o que eu fiz de errado? Por que comigo? Por que todo mundo, menos eu? Por que Deus estava querendo fazer isso comigo?"' (E14); "E aí, claro, quando acontece uma coisa assim a gente tem uma culpa. Com relação a N. especificamente, eu tinha algumas culpas de... eu não devia ter comido tal coisa, sabe? Por que comigo? Por que eu?" (E15). Uma das entrevistadas menciona o fato de ter se sentido culpabilizada pelo marido "Porque ele me culpou pela escolha do médico, no início ele me culpou pela perda e tudo isso. (...)Ele estava sofrendo, mas eu também não estava disposta a nenhum processo acusatório" (E3)

E3 considerou importante falar para as outras pessoas sobre a perda gestacional, para que o tema fosse considerado por todos como significativo. "Achei importante assim, não subir num palanque e falar o que tinha acontecido, mas assim, dividir a experiência pras pessoas saberem que é uma merda, entendeu?". O luto por perda gestacional ou neonatal é, muitas vezes, negado socialmente (Worden, 2013) e pode ser considerado como potencial complicador para o processo de luto, uma vez que, ao não ser reconhecido, o suporte adequado não pode ser oferecido (Doka, 2008).

De acordo com Casellato (2015), a impossibilidade de viver o luto pode partir da sociedade e até mesmo do próprio enlutado, que, para se defender das emoções provocadas pela perda, não reconhece o luto, o que é explicitado pelo discurso de E10: "Eu lembro que era como se eu não aceitasse que tivesse acontecido uma perda, assim, um luto de uma pessoa". O enlutado pode não se perceber como alguém que precisa de cuidados (Doka, 2008). O enlutado, muitas vezes, sente-se solitário em sua dor, pois identifica que os outros sequer reconhecem o vínculo. "Porque o pessoal acha assim, um enterro de um recémnascido, o que que eu vou chorar, né? Não tem muito assim... Só chorou quem realmente criou um vínculo, eu, meu esposo, essa minha amiga e o meu amigo" (E11). 
O fato se ser vivido como uma dor silenciosa torna o processo de luto por perda gestacional ou neonatal extremamente solitário e, consequentemente, mais difícil. "Ninguém sabia. Foi um processo só meu, do meu marido, da minha mãe. É um processo que você fica muito sozinha" (E2). "Pra mim também foi muito difícil porque foi muito silenciado. Eu fiquei em silêncio porque eu entendi que ninguém ali queria falar sobre isso. Eu passei uma semana sangrando em silêncio, literalmente sangrando em silêncio. Uma metáfora da vida, que no meu caso não era uma metáfora, era uma realidade" (E8). "Acaba que assim, eu sou muito reservada. Então, eu não compartilhei com muita gente não... Eu acho que eu nunca contei assim de maneira tão linear como eu estou contando pra você, ou na minha análise. Então, não foi um negócio muito compartilhado" (E17). Worden (2013) afirma que o fato de muitas mães evitarem tocar no assunto da perda e do luto, por não sentirem que sua dor é reconhecida ou até merecedora de suporte, faz com que os sentimentos de isolamento e desamparo sejam profundos.

Em contrapartida, muitas entrevistadas destacaram a importância do suporte recebido durante o processo de luto. Mendonça (2018) identifica o suporte social como importante recurso de apoio para as famílias, sendo um facilitador para o processo de luto. "Principalmente a equipe que trabalhava comigo, tudo cheio de atenção, todo mundo tranquilo comigo. Sempre alguma coisa nesse sentido pra... nessa questão de conforto mesmo" (E5). "Quando eu cheguei, as pessoas já sabiam o que tinha acontecido, então tinham um cuidado. Só era eu de psicóloga, eu dizia que não ia entrar e tudo bem, ninguém questionava nada. Tinha muita gente que me dava retaguarda pra isso" (E6). "Parte do que aconteceu que foi bem legal é que as amigas mais próximas do meu trabalho que acompanharam falaram pras pessoas o que tinha acontecido, então assim, me ajudou muito com o medo das perguntas no corredor" (E3). Cabe aqui destacar que as três entrevistadas interpretaram o suporte recebido no trabalho como efetivo.

Duas entrevistadas salientaram a dificuldade da sociedade em oferecer suporte adequado ao luto perinatal, enfatizando a falta de preparo, inclusive, de pessoas próximas, para lidarem com suas dores. "Acho que tiveram pessoas que tentaram fazer alguma coisa, que não sabiam o que fazer, tem gente que ao mesmo tempo não reconhece. Tive todo tipo de situação. Teve gente que tive que consolar quando contei" (E7); "Quando eu perdi de fato eu vi que as pessoas não estão prontas pra receber e pra dar apoio no luto" (E8). 
Os rituais de despedida foram lembrados por várias entrevistadas, especialmente as que tiveram perdas com mais de 20 semanas de gestação. De acordo com Doka (2006), os rituais de despedida têm um papel terapêutico, pois proporcionam um tempo delimitado para estar com outras pessoas, dividir memórias e receber suporte.

Mitima-Verloop, Mooren e Boelen (2019), identificam que os rituais marcam a transição na qual a irreversibilidade da morte pode ser enfatizada. Os rituais também são capazes de ajudar na concretização da perda vivida e favorecem a expressão das emoções (Doka, 2006). "Eu lembro muito dessa... Da despedida das roupinhas, das coisinhas que ele tinha e... Eu sou uma pessoa também de rituais, porque eu acho que eles me ajudam a materializar o assunto" (E12).

É fundamental que seja dada ao enlutado a opção de participar ou não dos rituais de despedida. Quando opções são dadas, segundo Doka (2006) o enlutado pode demonstrar sua capacidade de decidir, mesmo em uma condição de maior fragilidade. O enlutado pode optar por comparecer ou não ao ritual, ajudar na sua construção, construir um ritual individualizado... A experiência da E16 reflete as múltiplas possibilidades de participação nos rituais de despedida: "Eles subiram, foram lá, pegaram ela, viram e tal, o último contato. Eu não tive, o único contato que eu tive com ela foi no parto. Perguntaram se eu queria ir, eu não quis ir. Eu estava muito mal, assim, sei lá. A cabeça fica muito louca e eu preferi não ir. Aí, eles foram e tal, a partir dali já levaram pra empresa e fizeram a cremação dela. Quando eu cheguei em casa eu já quis logo entrar no quarto. Aí, eu peguei uma cadeira, pedi pra pegarem uma cadeira pra mim, sentei lá no quarto, sentou eu e o (marido) e a gente ficou muito tempo lá chorando, muito tempo. A gente chorou, chorou, chorou, chorou, se abraçou e chorou, chorou, chorou... Sei que assim, foi o nosso momento de... Sabe assim, sei lá... Sentir aquela coisa e saber que ela não iria estar ali, né? Aí, eu comecei a falar algumas coisas pra ela, como se fosse uma despedida, o J. (marido) também falou. E foi isso, assim. A gente saiu do quarto, fechou a porta. Quando foi em dezembro, que a gente veio na primeira semana de dezembro, que a gente veio e fez o enterro dela, e tal. Nossa família, minhas amigas... Foi uma cerimônia, assim, bem simples. Só foi mesmo os nosso pais, nossos irmãos, os meus sobrinhos e minhas amigas mais próximas. E eu senti que o ciclo tinha fechado no dia do enterro, sabe assim, até então eu estava com a ferida super aberta, aí a partir do enterro, desse momento que eu senti o ciclo fechar". Uma 
despedida com sentido é capaz de auxiliar o enlutado no processo de integração do luto.

A questão do não-reconhecimento do luto (Doka, 1989,2008) está presente também na dificuldade de realização dos rituais, evidenciada por E17 "Eu me lembro até da pessoa do cemitério falando, 'ah, quando é natimorto, não faz velório', eu falei ‘ele não é natimorto, ele nasceu, ele viveu dois dias. Ele não nasceu morto'. Mas eu entendi que na realidade, enfim né, é uma... porque tudo entra no grupo de perda gestacional, né, na realidade eu tive a sorte dele viver dois dias, né, porque a tendência era que ele nascesse efetivamente morto".

E11 traz a questão do ritual de despedida associada à apresentação do filho morto à sua família "eu saí do hospital, vim pra casa, tomei um banho e comi, a gente almoçou e a gente foi pro cemitério. Não! Antes de eu ir pro cemitério, a gente foi no necrotério e foi aí que eu tirei a foto. Eu tirei foto dele assim nu só pra... Minha mãe ver...O pessoal conhecer ele, da minha família”. O sentido dos rituais deve ser construído pelo próprio enlutado e, quando significativos, são capazes de ser veículo no processo de transição e continuidade (Mitima-Verloop, Mooren \& Boelen, 2019).

E3, membro da comunidade judaica, pontua as especificidades do judaísmo no que diz respeito à ausência de rituais em situação de perdas gestacionais ou natimortos. "Tem uma ala no cemitério que é só para esses bebês. Natimortos e tal, que é no começo do cemitério. Também não teve reza, não tem nada”. Ao falar sobre essa questão, ela se confunde sobre onde está o fillho "Eu não sei onde está internado, internado não, enterrado".

Após a perda gestacional na 30ª semana, E16 descreve a intensidade de seu sofrimento: "Eu sofri muito, muito, assim. Eu emagreci dezesseis quilos... em quarenta e cinco dias, por aí, sabe? Eu não conseguia comer, eu não conseguia respirar, assim, era uma dor enorme, enorme que eu sentia, sabe? Eu sentia ânsia de vômito. Me afastei totalmente de todo mundo. Eu tentava ainda manter um social, mas as grávidas eu não tinha contato, não conseguia ver. Fiquei bem isolada". Ressalta-se aqui a intensidade do da dor e do sofrimento, entretanto, tais reações são compatíveis com a resposta de luto agudo a uma perda significativa. Cassaday (2018) identifica como possíveis reações a esse tipo de perda dor intensa, culpa, raiva, isolamento, tristeza, desespero que são sucedidas, em algum momento, por uma adaptação à perda e reconstrução da vida sem o bebê. 


\begin{tabular}{|c|c|c|}
\hline & $\begin{array}{l}\text { Categorias de Análises - NOVA } \\
\text { GRAVIDEZ }\end{array}$ & Informações obtidas \\
\hline 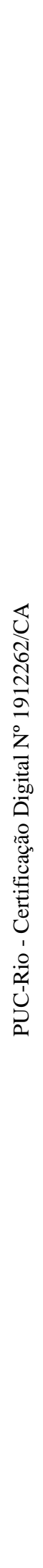 & Planos nova gravidez & 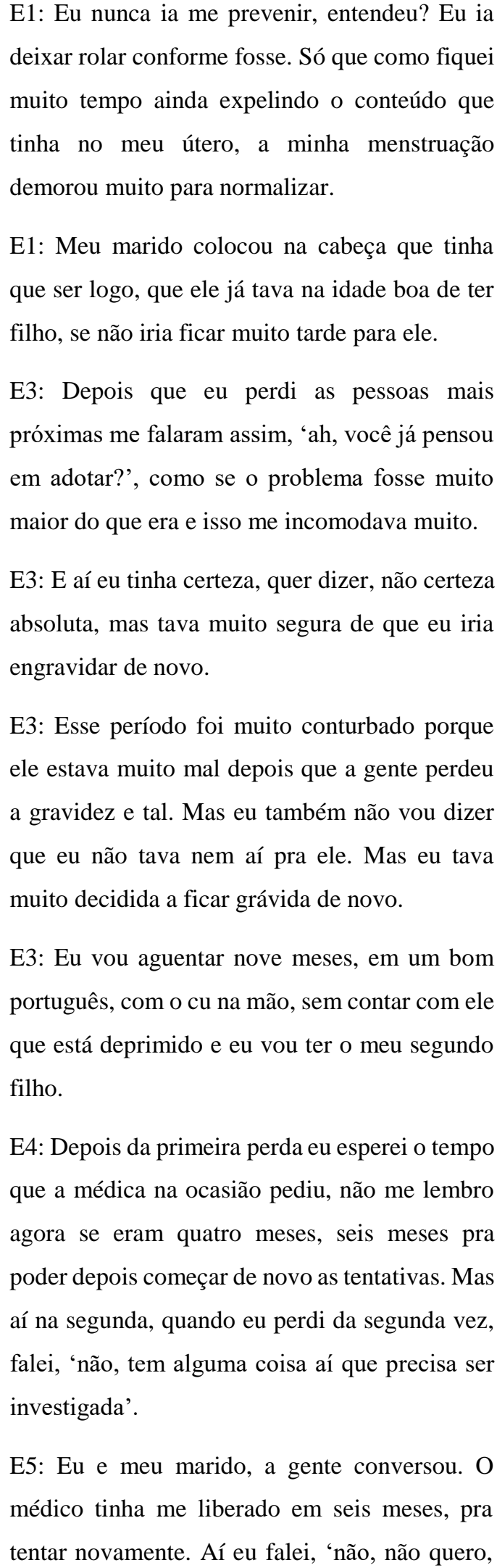 \\
\hline
\end{tabular}




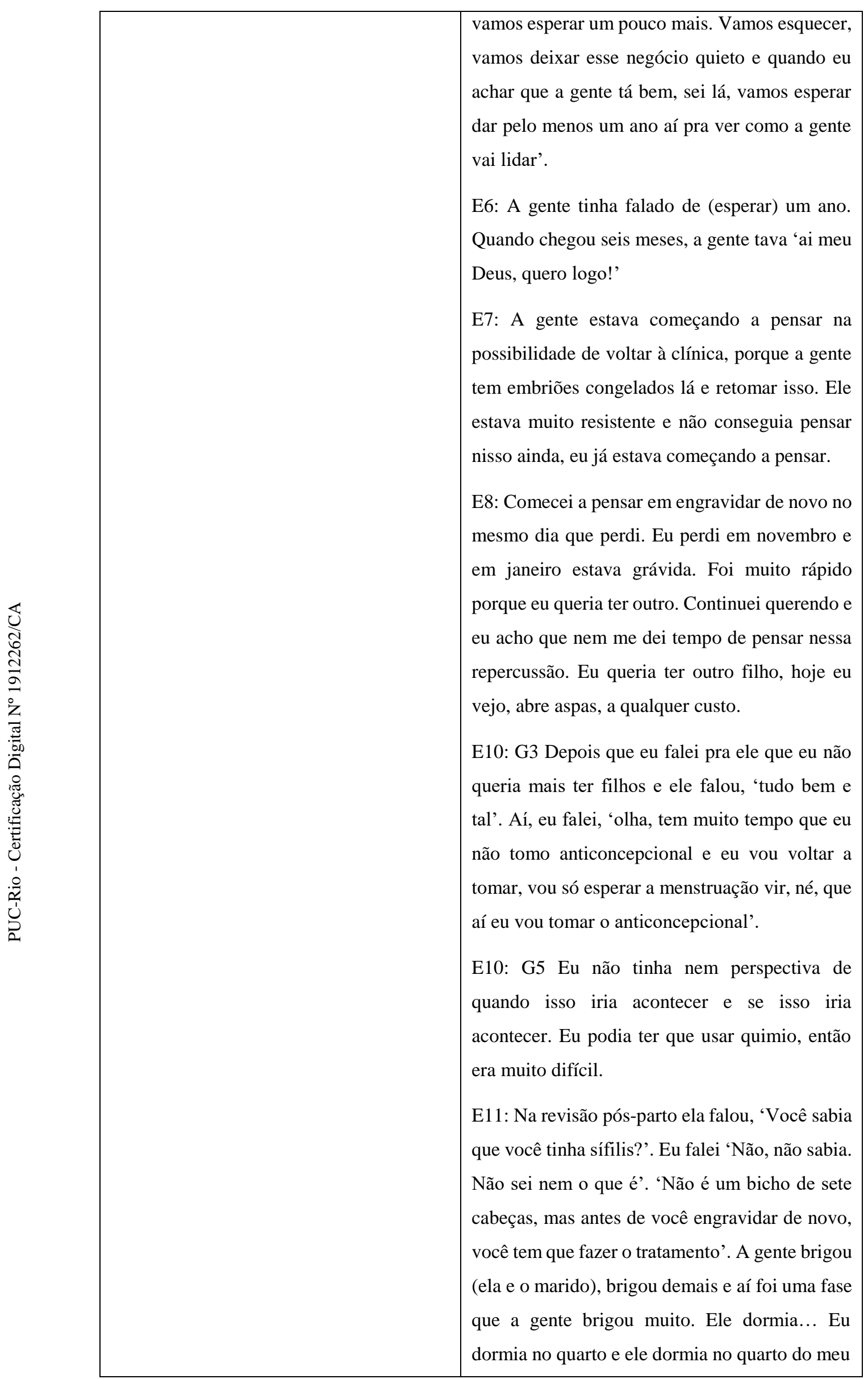




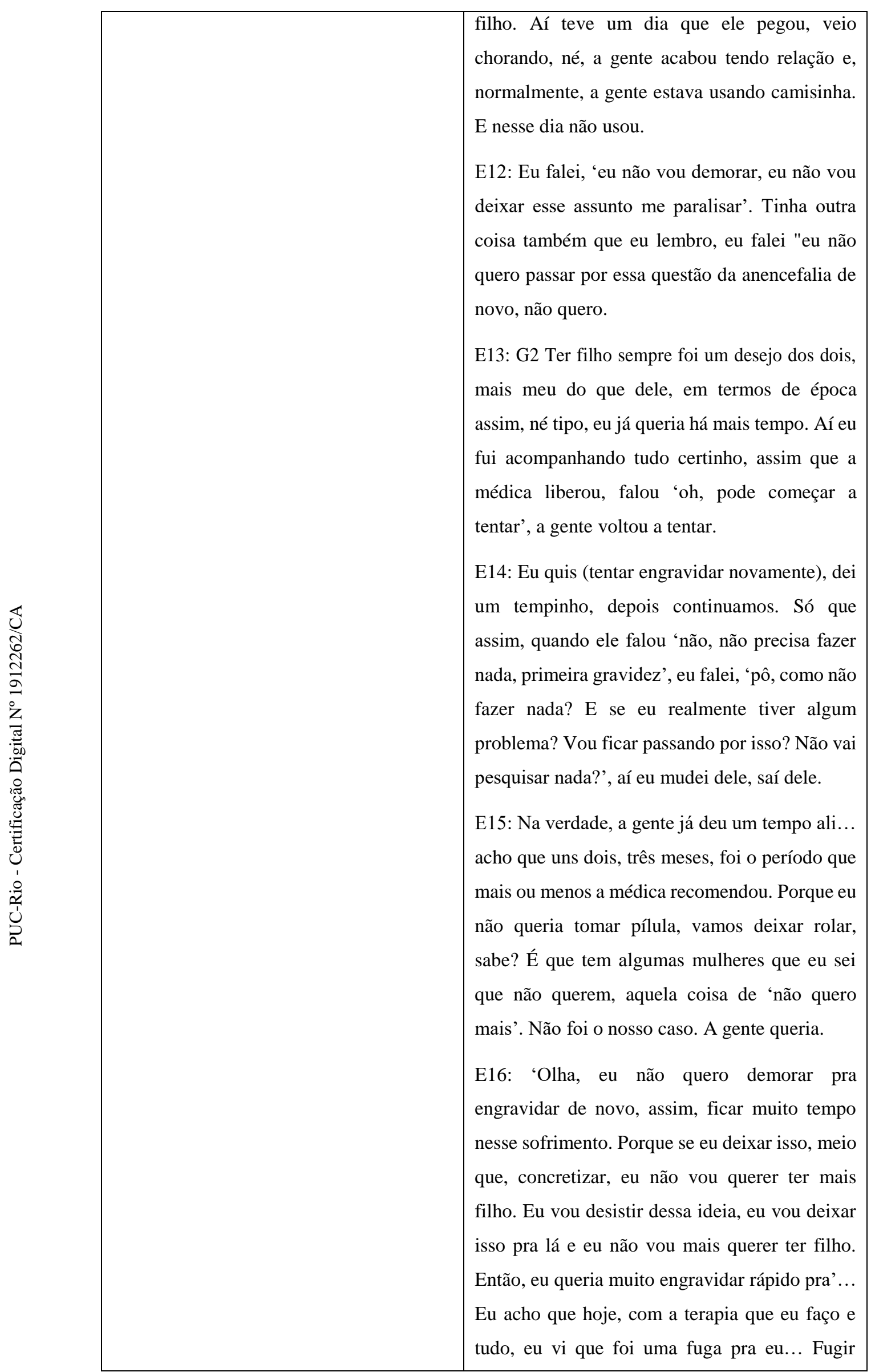




\begin{tabular}{|c|c|}
\hline & $\begin{array}{l}\text { daquela dor, sabe assim...Ter um filho pra mim } \\
\text { era uma questão de sobrevivência, sabe? A } \\
\text { minha dor era tão insuportável, era uma coisa tão } \\
\text { forte, tão pesada...Eu queria arrumar um jeito de } \\
\text { fugir de sentir aquilo. } \\
\text { E17: Logo depois que eu perdi o G. eu fui nessa } \\
\text { médica nova, aí ela me ajudou a fazer esse } \\
\text { rastreio pra ver o que eu conseguia descobrir da } \\
\text { perda do G. e nisso ela já falou, 'Olha, o ideal } \\
\text { seria você esperar mais tempo, mas dá pra você } \\
\text { só esperar seis meses e você começa a tentar } \\
\text { depois'. }\end{array}$ \\
\hline Compartilhar a notícia & $\begin{array}{l}\text { E1: Vontade inicial era segurar até } 12 \text { semanas. } \\
\text { É melhor que a gente conte e tenha esse, caso } \\
\text { aconteça novamente, e tenha esse tipo de carinho } \\
\text { das pessoas do que ficar sofrendo sozinho. } \\
\text { E2: A gente não contou pra ninguém. Nada a } \\
\text { gente contava, tudo nosso era segredo. Tudo } \\
\text { nosso era só nós dois. } \\
\text { E2: Minha mãe só ficou sabendo que eu tava } \\
\text { grávida com cinco meses e meio. } \\
\text { E2: Contei pra ninguém. } \\
\text { E3: Eu não falava com as pessoas que eu estava } \\
\text { grávida. } \\
\text { E3: Eu segurei até onde dava, só eu com meu } \\
\text { marido. E aí eu falei pra minha mãe depois de } \\
\text { uns três meses e meio. Essa gravidez foi uma } \\
\text { coisa muito minha. } \\
\text { E4: Eu esperei para espalhar a notícia. Meus } \\
\text { irmãos, minha cunhada, meus pais sabiam, desde } \\
\text { o início mesmo. Mas assim, amigos eu acho que } \\
\text { segurei um pouquinho mais para compartilhar } \\
\text { porque a gente já fica descolada. } \\
\text { E5: Aprendi muito a esperar e não sair contando } \\
\text { pra todo mundo. Aprendi na segunda gestação a } \\
\text { não avisar antes, esperar um pouquinho pra } \\
\text { avisar. }\end{array}$ \\
\hline
\end{tabular}




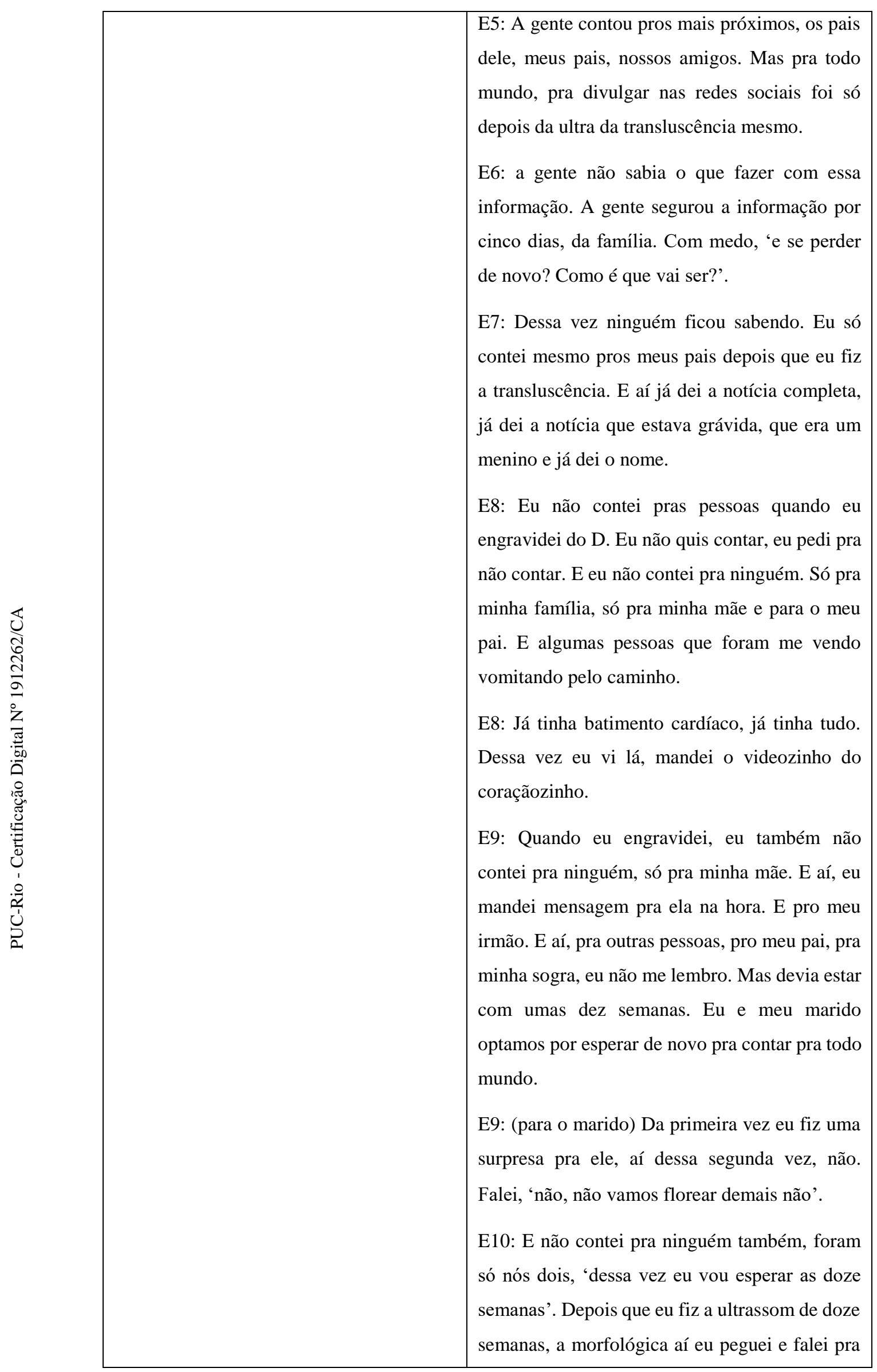




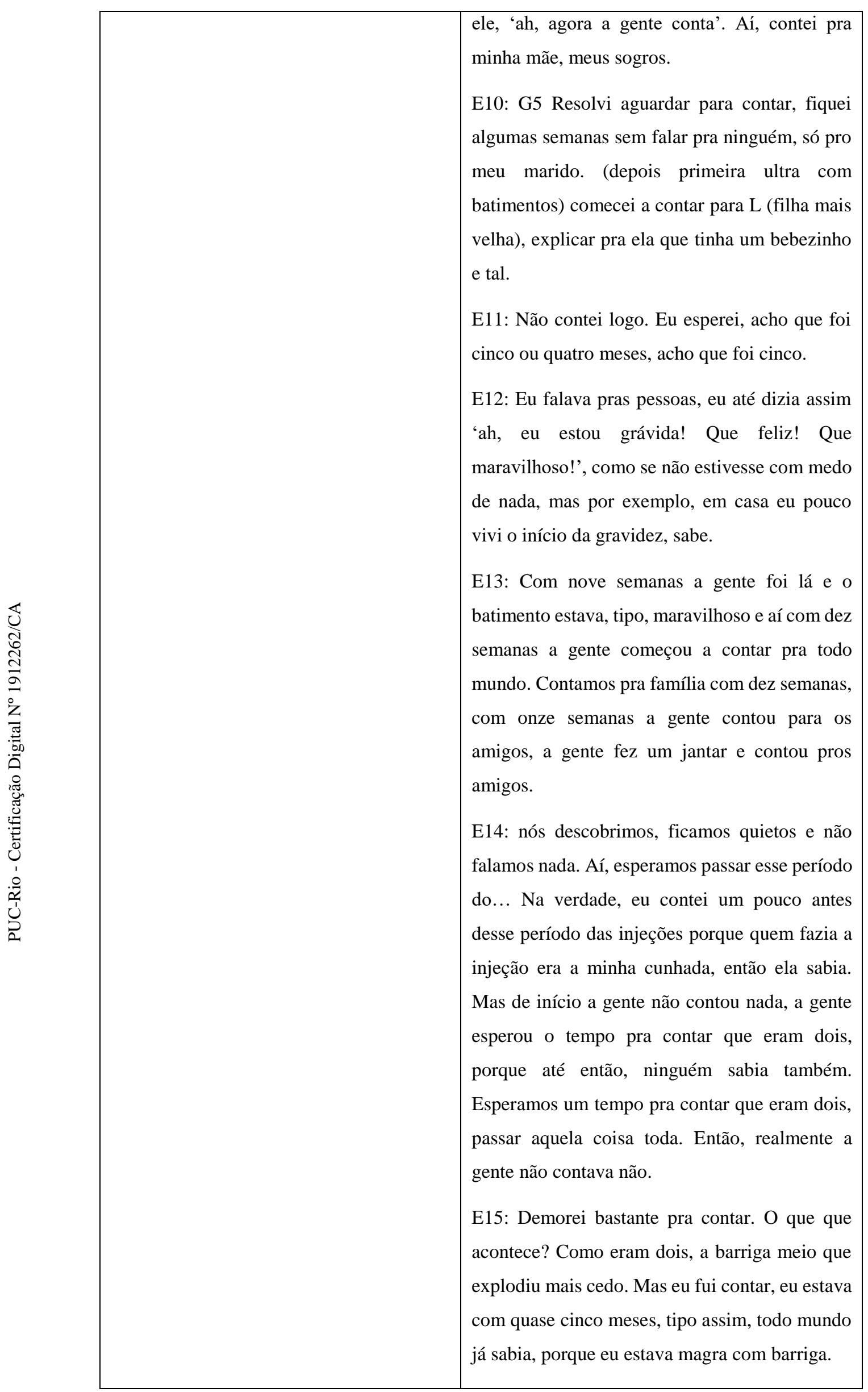




\begin{tabular}{|c|c|}
\hline & $\begin{array}{l}\text { E16: Foi um outro tipo de reação, né, a gente já } \\
\text { ficou calado, não quisemos contar pra ninguém, } \\
\text { só contamos para os nossos pais, só contou para } \\
\text { os pais do J. e pra minha mãe, ficou naquela } \\
\text { coisa, sabe? Só com treze semanas que a gente } \\
\text { começou a falar para as pessoas, mas, mesmo } \\
\text { assim, só pra pessoas muito próximas. } \\
\text { E17: Eu contei pra minha psicanalista, pro meu } \\
\text { pai, pra minha mãe, pra minha irmã e pouco } \\
\text { tempo depois, eu já tive que começar a contar } \\
\text { pra alguns contatos que são amigas, mas que } \\
\text { vieram da vida profissional. }\end{array}$ \\
\hline Enxoval do bebê/Preparativos & 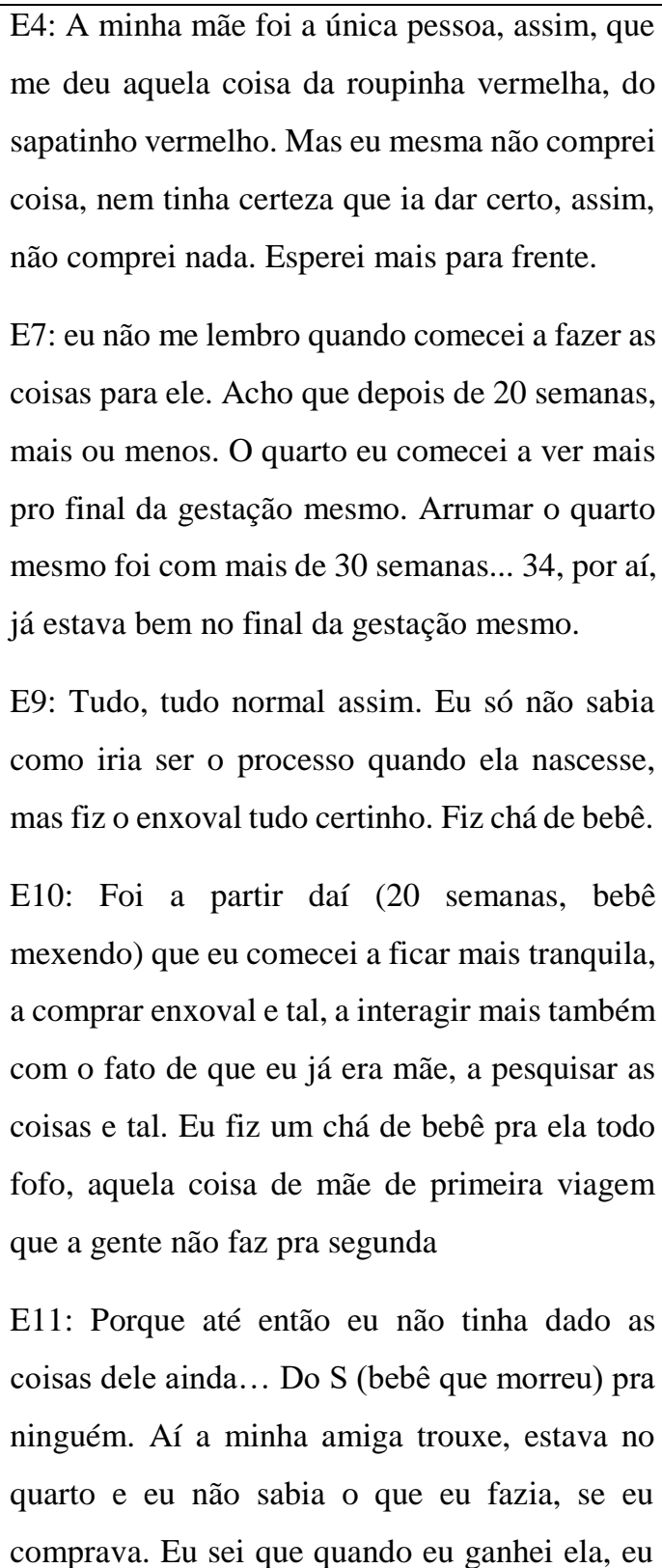 \\
\hline
\end{tabular}




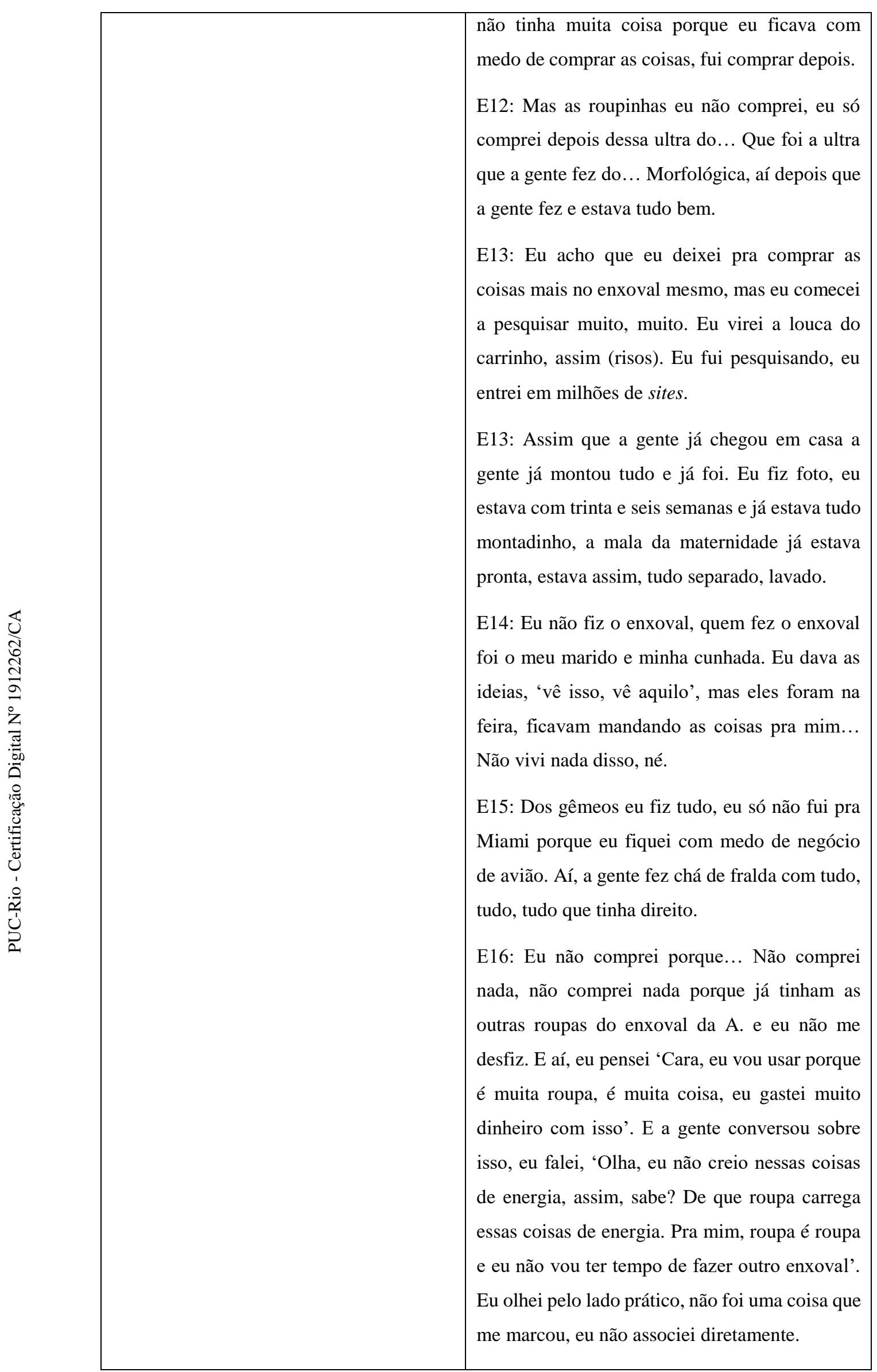




\begin{tabular}{|c|c|}
\hline & $\begin{array}{l}\text { E16: Aí eu fiquei nessa, 'Faço ou não faço, faço } \\
\text { ou não faço'. Quem me encorajou a fazer todas } \\
\text { essas coisas foi o J., ele falava "não, tem que } \\
\text { fazer. Tem que fazer sim, é importante que faça, } \\
\text { ela precisa. Não é pela gente, é pela I. que a gente } \\
\text { vai fazer", e tal. Aí, eu fiz e foi uma gracinha, } \\
\text { sabe, bem bonitinho, tudo bem ajeitadinho e os } \\
\text { nossos amigos foram, a gente ganhou muita } \\
\text { fralda, porque a gente fez só chá de fraldas, né. } \\
\text { E17: Mas, foi uma gravidez muito gostosa. Eu } \\
\text { fiz tudo que eu tinha direito, eu fiz chá de bebê, } \\
\text { eu fiz ensaio de grávida }\end{array}$ \\
\hline Medo & 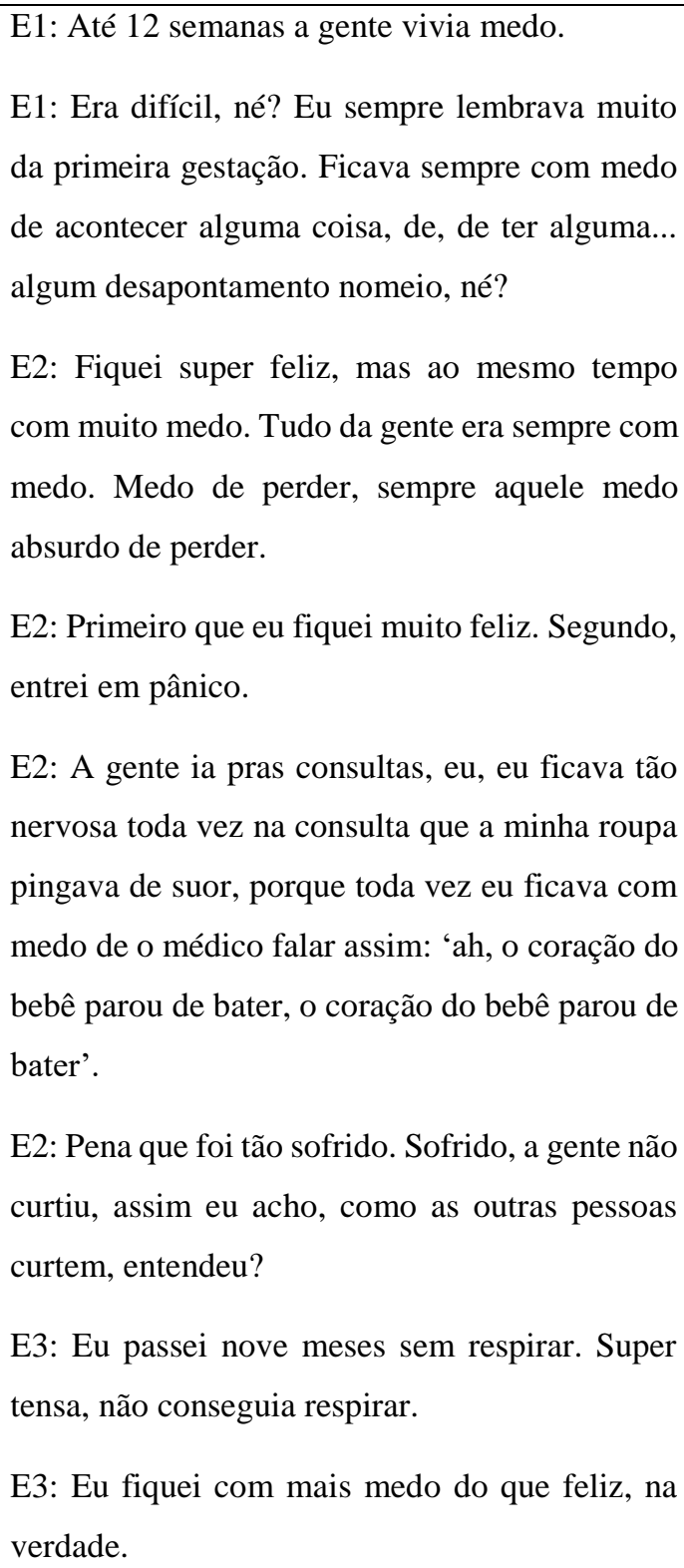 \\
\hline
\end{tabular}




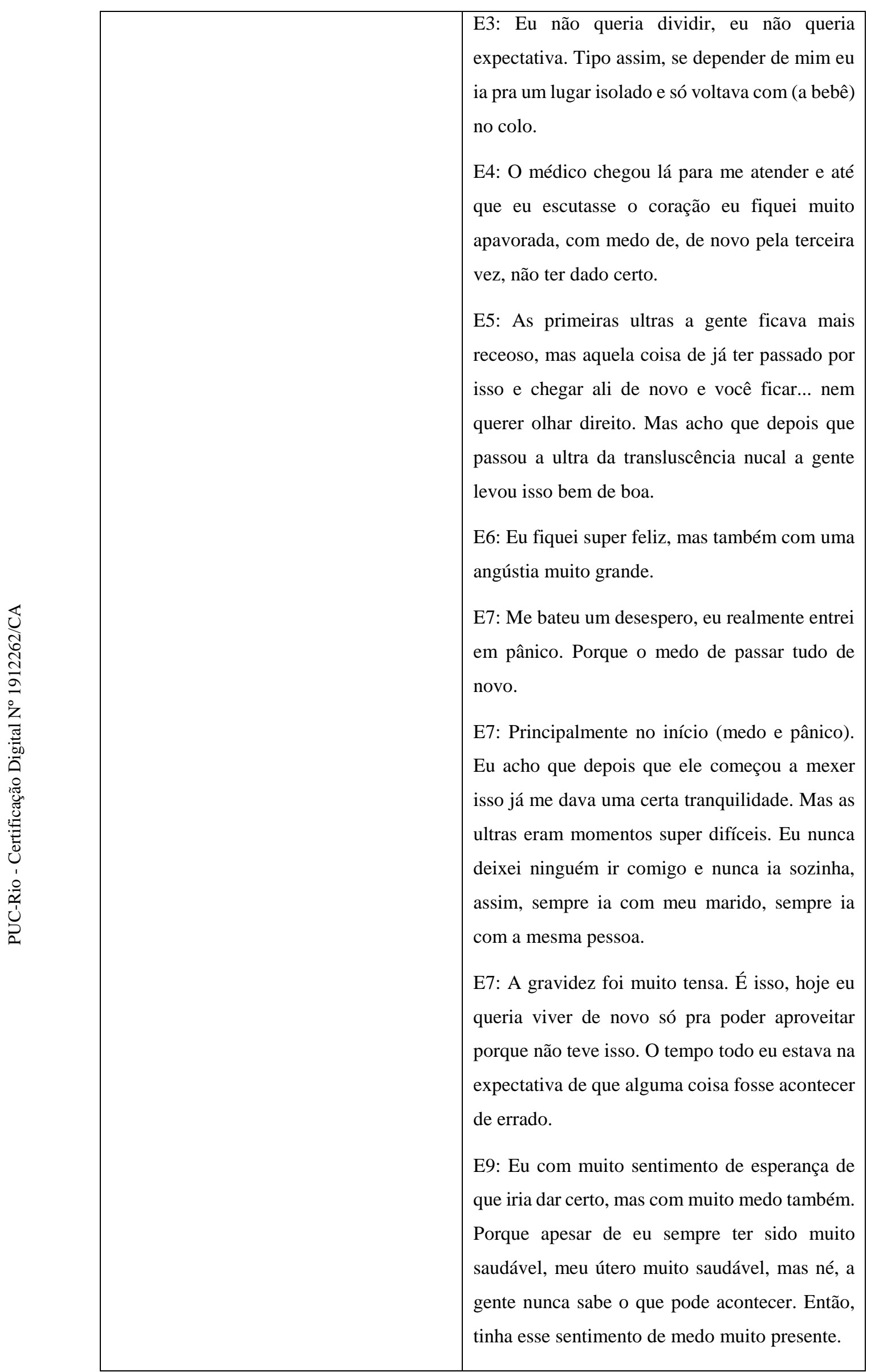




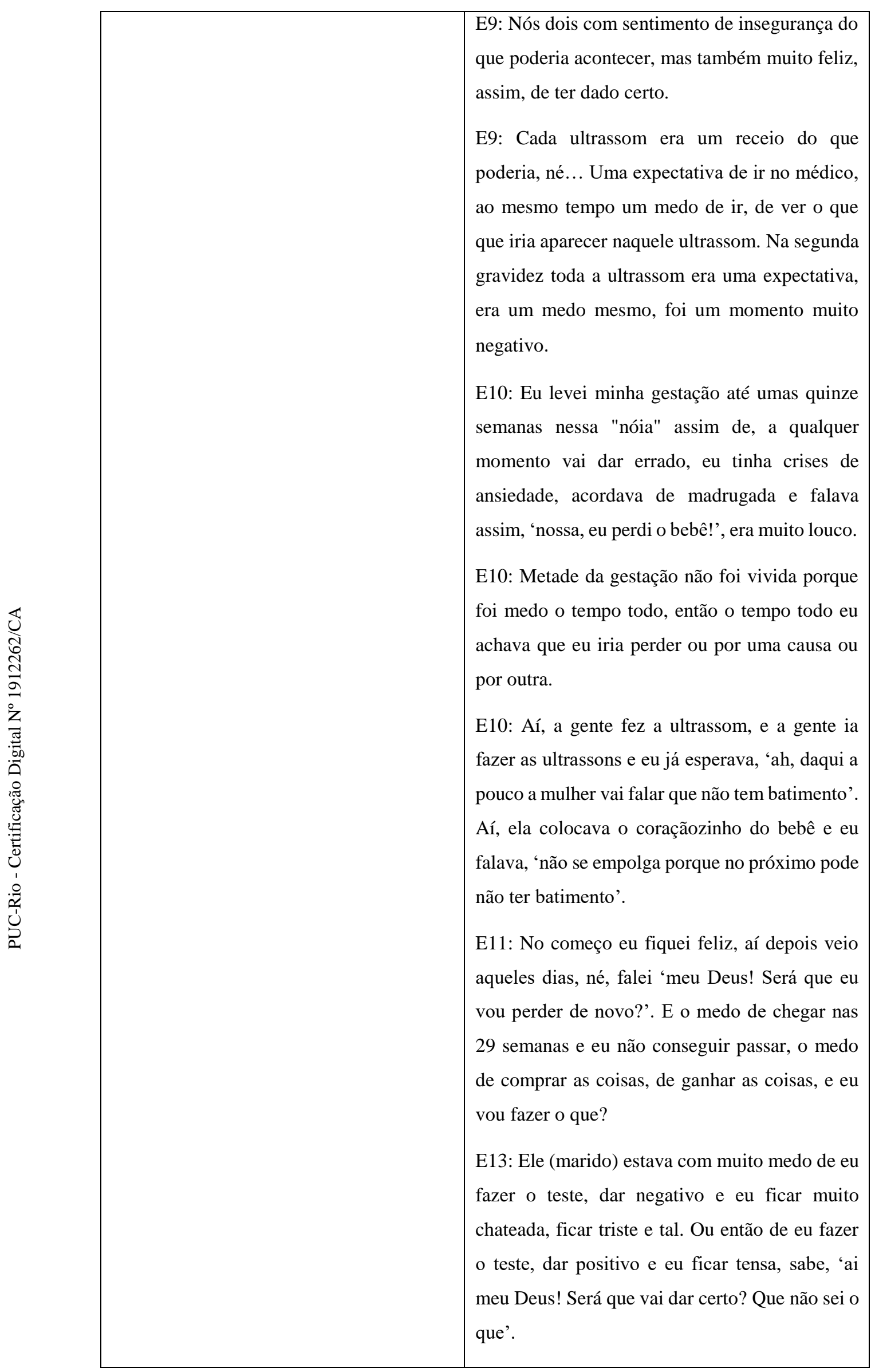




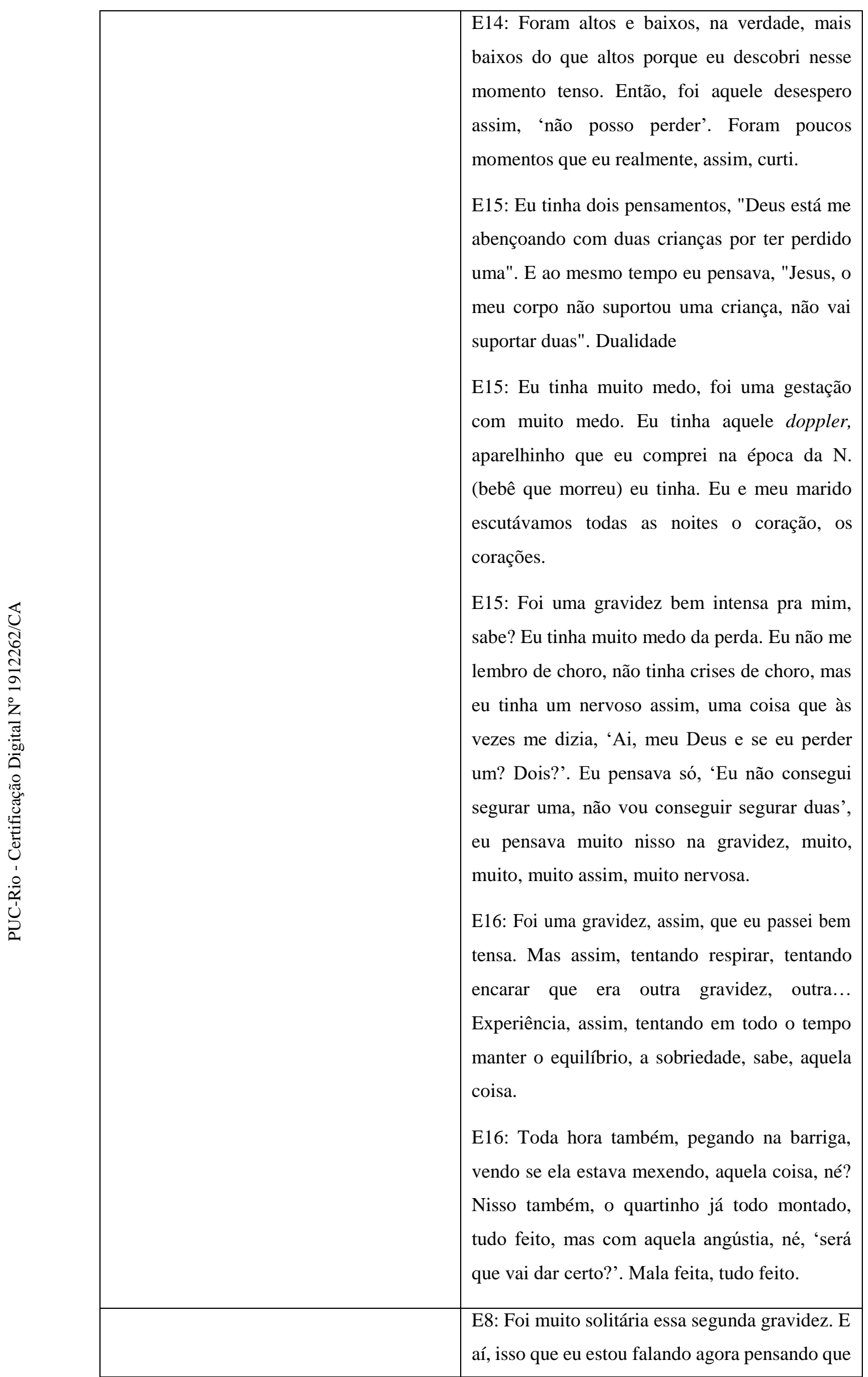




\begin{tabular}{|c|c|}
\hline & $\begin{array}{l}\text { tinha esse luto junto, não sei até que ponto eu fui } \\
\text { me fechando, me fechando, me fechando, sem } \\
\text { saber onde eu estava. Se eu estava tendo a real } \\
\text { dimensão que essa perda teve. }\end{array}$ \\
\hline Vínculo & 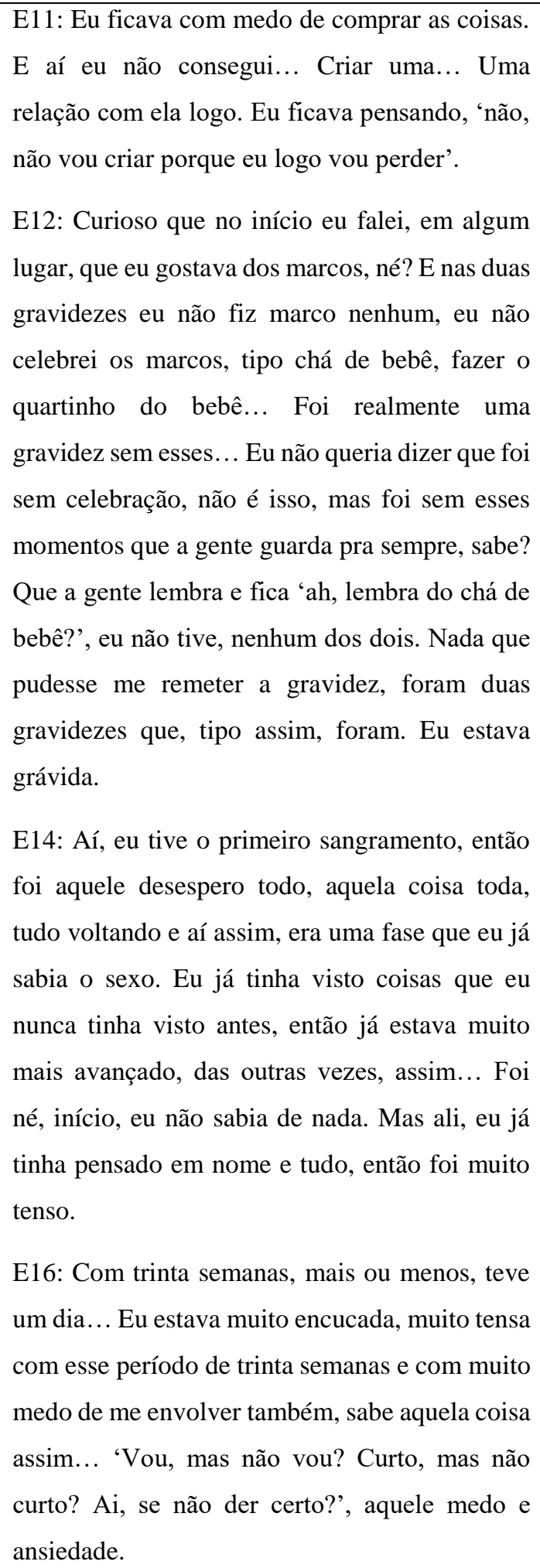 \\
\hline
\end{tabular}




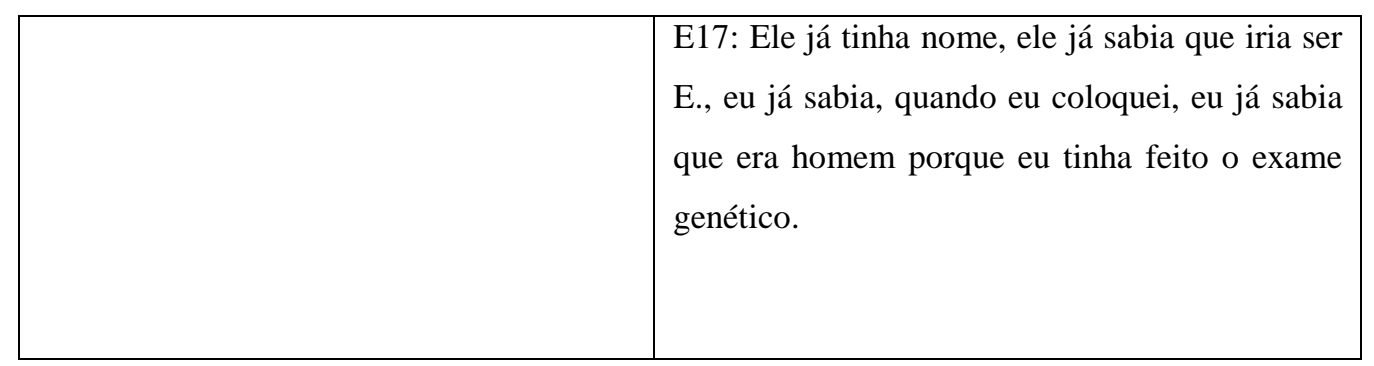

Foram muitos os relatos de medo intenso durante a gravidez. O medo e a insegurança são reações comuns a perdas significativas, uma vez que, segundo Parkes (2009), o luto envolve muito mais do que uma situação de pesar e nos coloca em contato com a sensação de ameaça. "Eu passei nove meses sem respirar. Super tensa, não conseguia respirar. Eu fiquei com mais medo do que feliz” (E3); “O médico chegou lá para me atender e até que eu escutasse o coração eu fiquei muito apavorada, com medo de, de novo, pela terceira vez, não ter dado certo" (E4); Metade da gestação não foi vivida porque foi medo o tempo todo, então o tempo todo eu achava que eu iria perder ou por uma causa ou por outra" (E10); “O tempo todo eu estava na expectativa de que alguma coisa fosse acontecer de errado". Há uma quebra do mundo presumido (Parkes, 2009) e o que antes estava garantido, hoje não mais está. Lee, McKenzie-McHarg e Horsch (2013) corroboram a presença da sensação de ameaça e insegurança após uma perda gestacional ou neonatal, identificando aumento da ansiedade e preocupação intensa com a gravidez subsequente. A mães deixam passam a não mais idealizar a gestação e experienciam preocupação e medo profundos. E15 "Eu tinha muito medo, foi uma gestação com muito medo. Eu tinha aquele doppler, aparelhinho que eu comprei na época da $\mathrm{N}$. (bebê que morreu). Eu e meu marido escutávamos todas as noites o coração, os corações"

Algumas mães destacaram a presença de sentimentos e expectativas ambivalentes relacionados à nova gravidez subsequente à perda gestacional. "No começo eu fiquei feliz, aí depois veio aqueles dias, né, falei 'meu Deus! Será que eu vou perder de novo?' (E11). “muito sentimento de esperança de que iria dar certo, mas com muito medo também” (E9); “Eu fiquei super feliz, mas também com uma angústia muito grande" (E6); "Eu lembro de saber que iria dar tudo certo, mas assim, eu fiquei super reservada" (E3). Armstrong (2002) destaca a necessidade de que os profissionais de saúde estejam atentos e aprofundem sua compreensão a respeito da mistura de sentimentos como esperança e medo envolvidos em uma 
gravidez subsequente à perda gestacional e neonatal. O endereçamento e cuidado adequados dessas questões de ambivalência podem influenciar tanto no curso da gravidez como também no relacionamento futuro entre mãe e bebê. E12 sentia que tinha atitudes contraditórias em relação à gravidez dentro e fora de casa: "Pras pessoas eu lembro que eu gostava muito de seguir o padrão grávida, digamos, ideal, mas em casa eu me fechava muito, me retraía muito, falava pouco, fazia as coisas fingindo que não estava grávida. Eu tinha um pouco essa dualidade, do que eu era em casa e do que eu era pros outros". Para Lee, Mc-Kenzie-McHarg e Horsch (2013), a sociedade espera que a gravidez deva ser sempre algo feliz e positivo, os desafios vivenciados pelas mães em gravidezes subsequentes a uma perda não costumam ser validados. Dessa forma, algumas mães mascaram seus sentimentos e vivem suas dúvidas, conflitos, inseguranças e preocupações isoladamente. Se o enlutado não é reconhecido, se a sua forma de viver o luto não é reconhecida, o suporte adequado não pode ser oferecido.

Além do medo de uma nova perda, algumas entrevistadas relataram medo de se vincular ao novo bebê, especialmente em situações de perdas gestacionais recorrentes e perdas tardias. Gaudet et al (2010) referem que em gravidezes precoces após uma perda tardia são identificados alta ansiedade e apego reduzido à nova gestação. E11 perdeu seu bebê com 29 semanas de gestação e relata "Eu ficava com medo de comprar as coisas. E aí eu não consegui... Criar uma... Uma relação com ela logo. Eu ficava pensando, não, não vou criar porque eu logo vou perder". E16 também referiu medo de vincular-se ao novo bebê “(...) com muito medo de me envolver também, sabe aquela coisa assim... Vou, mas não vou? Curto, mas não curto? Ai, se não der certo?, aquele medo e ansiedade”. Lee, McKenzieMcHarg e Horsch (2013) apontam que uma das estratégias utilizadas pelas mães em gravidezes subsequentes à perda gestacional é resistir ao apego, evitando a preparação para a chegada, por exemplo. "Nas duas gravidezes (depois da perda) eu não fiz marco nenhum, eu não celebrei os marcos, tipo chá de bebê, fazer o quartinho do bebê... Foi realmente uma gravidez sem esses... Eu não queria dizer que foi sem celebração, não é isso, mas foi sem esses momentos que a gente guarda pra sempre, sabe?" (E12). Assim como na pesquisa de Armstrong (2002), esses resultados desafiam a crença de que uma nova gravidez diminui as preocupações e o luto, e confirmam a presença de estresse significativo durante a gravidez subsequente. 


\section{Categorias de Análises - PRIMEIRAS Informações obtidas INTERAÇÕES / VÍNCULO ATUAL}

Nascimento

E3: Eu estava super nervosa, mas cara, quando eu vi (a bebê) chorar, foi muito bom, muito assim. Com o nascimento dela eu finalizei esse episódio. Cara, e aí assim, cara, eu chorei muito. Quando (a bebê) chorou, eu assim, eu desabei pra caralho e acabou, fechei o livro, página virada e vamos embora!

E4: Foi uma emoção gigante. Nossa! Eu fiquei muito emocionada.

E4: Muito lindo. É uma vivência inesquecível. E5: É uma emoção. A gente não consegue nem descrever. Você vê aquela coisa pequenininha, você nem acredita que saiu dali de dentro de você. Os olhos logo enchem de água... vermelho, até. A gente tem a foto, meu olho tá vermelhão.

E6: O meu pai, nervoso, não conseguia me explicar e explicou pra meu marido e meu marido me explicou. Eu relaxei dois por cento, mas continuei super nervosa.

E8: Ele nasceu! E pra mim foi incrível assim, eu queria muito ter ele, muito feliz.

E12: Acho que foi realmente esse nascimento de alívio de concretização. Aquele alívio, aquela felicidade absurda.

E13: Foi tipo, sei lá... A melhor sensação do mundo. Eu virei pro meu marido e falei que eu queria estar ali umas dez vezes (risos).

E14: Eu ficava assim, 'gente, eu quero ver, quero ver, quero ver', aí colocaram os dois do meu lado, tem a foto, aí eu vi e, assim, eu uso lente de contato porque eu sou mega míope. 


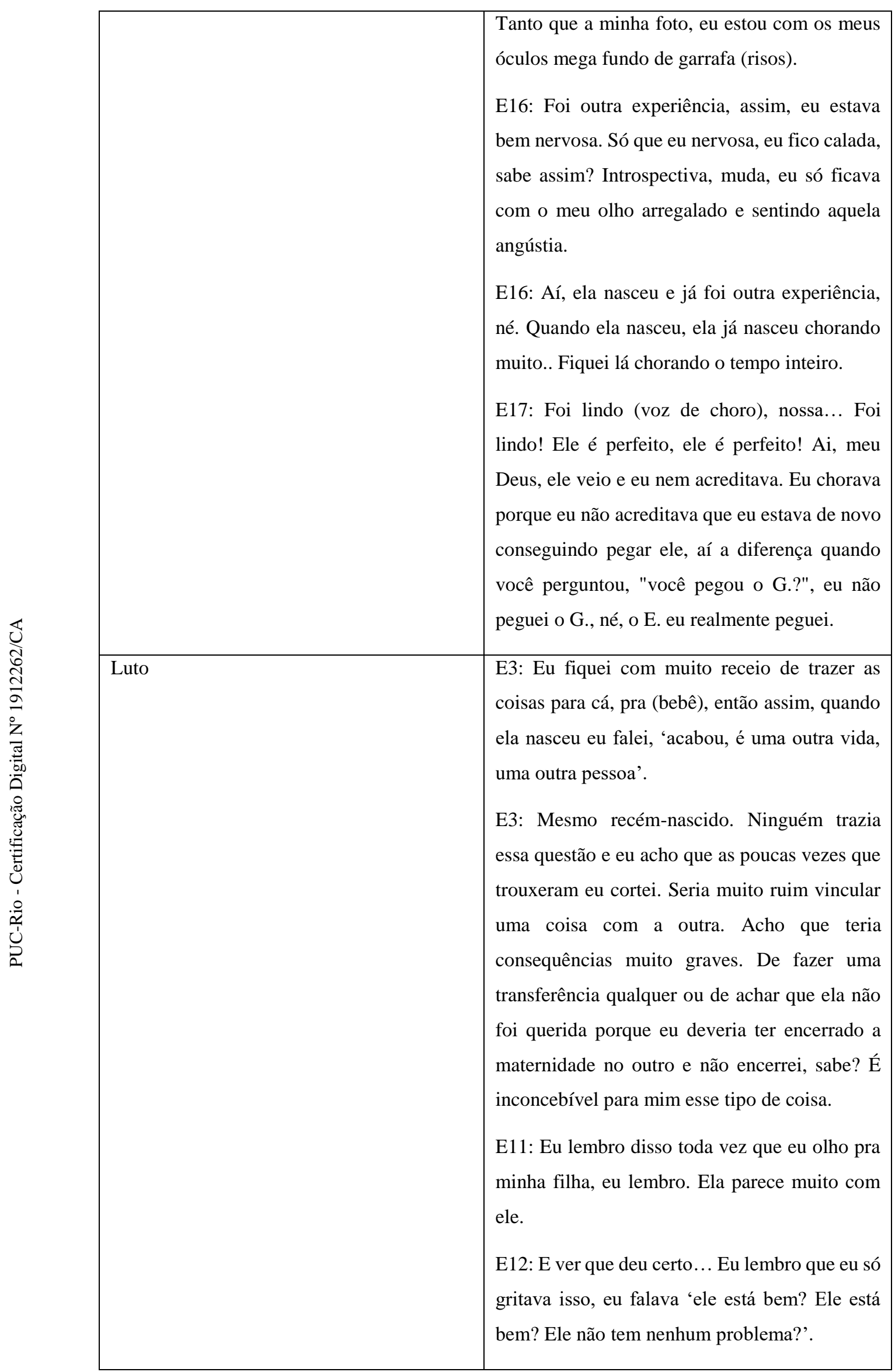




\begin{tabular}{|c|c|}
\hline & $\begin{array}{l}\text { E17: Logo no início teve uma coisa, "'caramba', } \\
\text { eu consegui ter um filho", sabe? "Eu consegui } \\
\text { vir com o meu filho pra casa, entrar com ele em } \\
\text { casa". No primeiro dia foi um... Enfim. Usar o } \\
\text { quarto que ficou quase dois anos e meio parado, } \\
\text { foi um... Enfim. Eu fico muito feliz de ter } \\
\text { conseguido usar o quarto que hoje é o quarto do } \\
\text { E., o E. sabe, eu já falei milhares de vezes pra } \\
\text { ele que ele teve um irmão e ele sabe também que } \\
\text { a B. está na minha vida muito porque eu perdi o } \\
\text { G., enfim. }\end{array}$ \\
\hline Conexão emocional/Proximidade & $\begin{array}{l}\text { E3: Eu era a pessoa mais próxima dela porque o } \\
\text { meu marido teve dificuldade de interagir muito } \\
\text { com ela no começo. } \\
\text { E3: Era muito eu e ela no começo, porque ela } \\
\text { estranhava, ela chorava e etc. } \\
\text { E9: Aquele sentimento de mãe, de maternidade } \\
\text { começou a aparecer mais forte porque até então } \\
\text { eu não tinha experiência. } \\
\text { E13: Assim, no minuto que a gente viu o } \\
\text { palitinho, ele (pai) já estava conectado, assim, } \\
\text { com ela. Já estava presente mesmo longe, a } \\
\text { gente fazia face time e ele falava comigo no viva } \\
\text { voz e ela mexia toda na barriga, assim sabe? } \\
\text { Então assim, já era uma coisa muito forte entre } \\
\text { os dois, sabe } \\
\text { E16: No começo eu não senti aquele amor } \\
\text { incondicional que todo mundo fala que sente, } \\
\text { sabe, aquele "nossa! É um amor que não cabe } \\
\text { no peito, que não sei o que". E depois, com o } \\
\text { passar do tempo que eu fui criando um vínculo } \\
\text { mais afetivo e tudo. Eu cuidava, não tive } \\
\text { rejeição, não tive nada por ela. Cuidava, me } \\
\text { envolvia com ela e tudo, só que o meu vínculo } \\
\text { com ela foi sendo construído com o passar dos } \\
\text { dias... Sabe assim? }\end{array}$ \\
\hline Dificuldades & $\begin{array}{l}\text { E1: A amamentação também foi difícil para } \\
\text { mim no início, mas eu queria fazer tudo, não }\end{array}$ \\
\hline
\end{tabular}




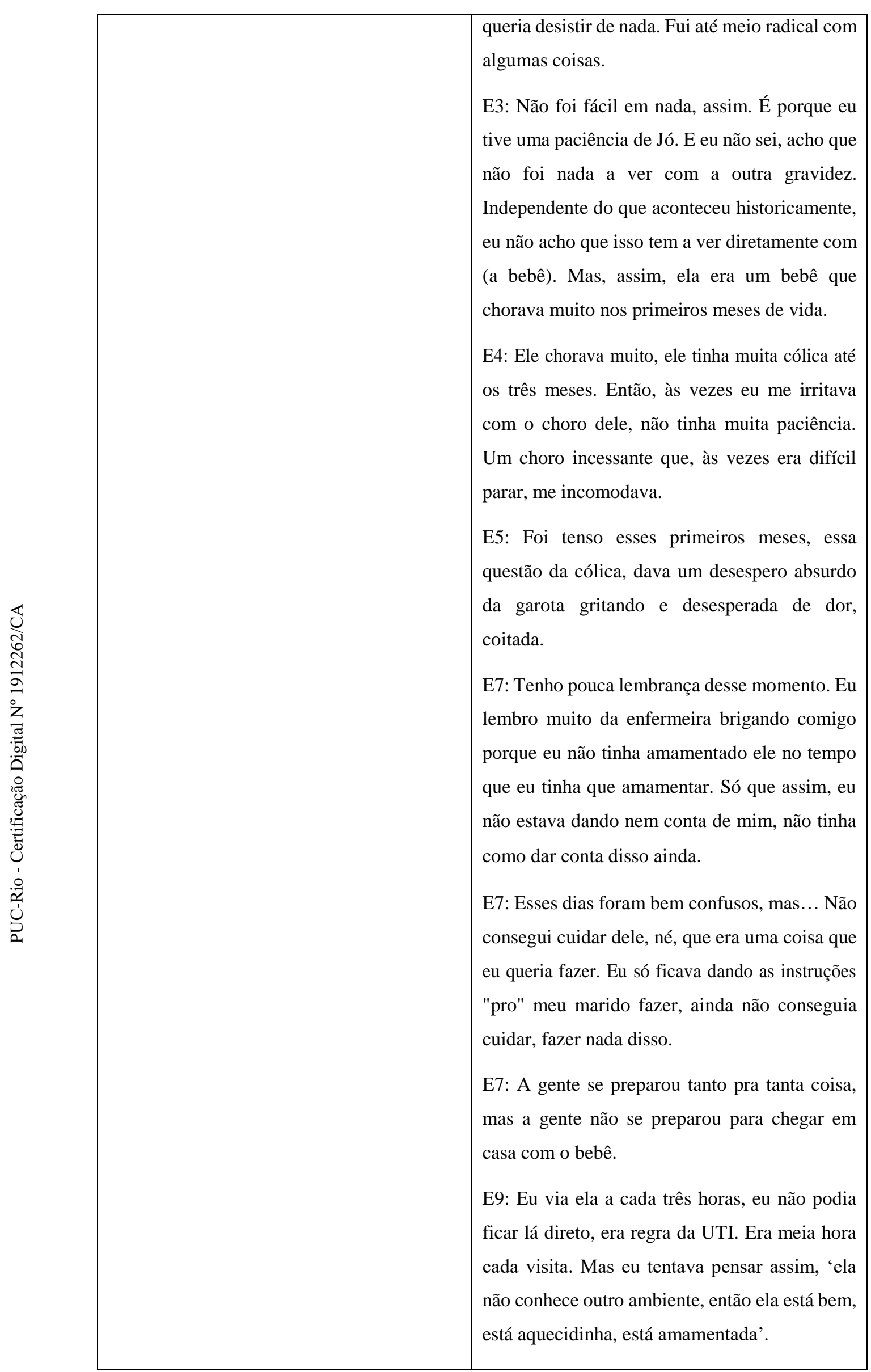




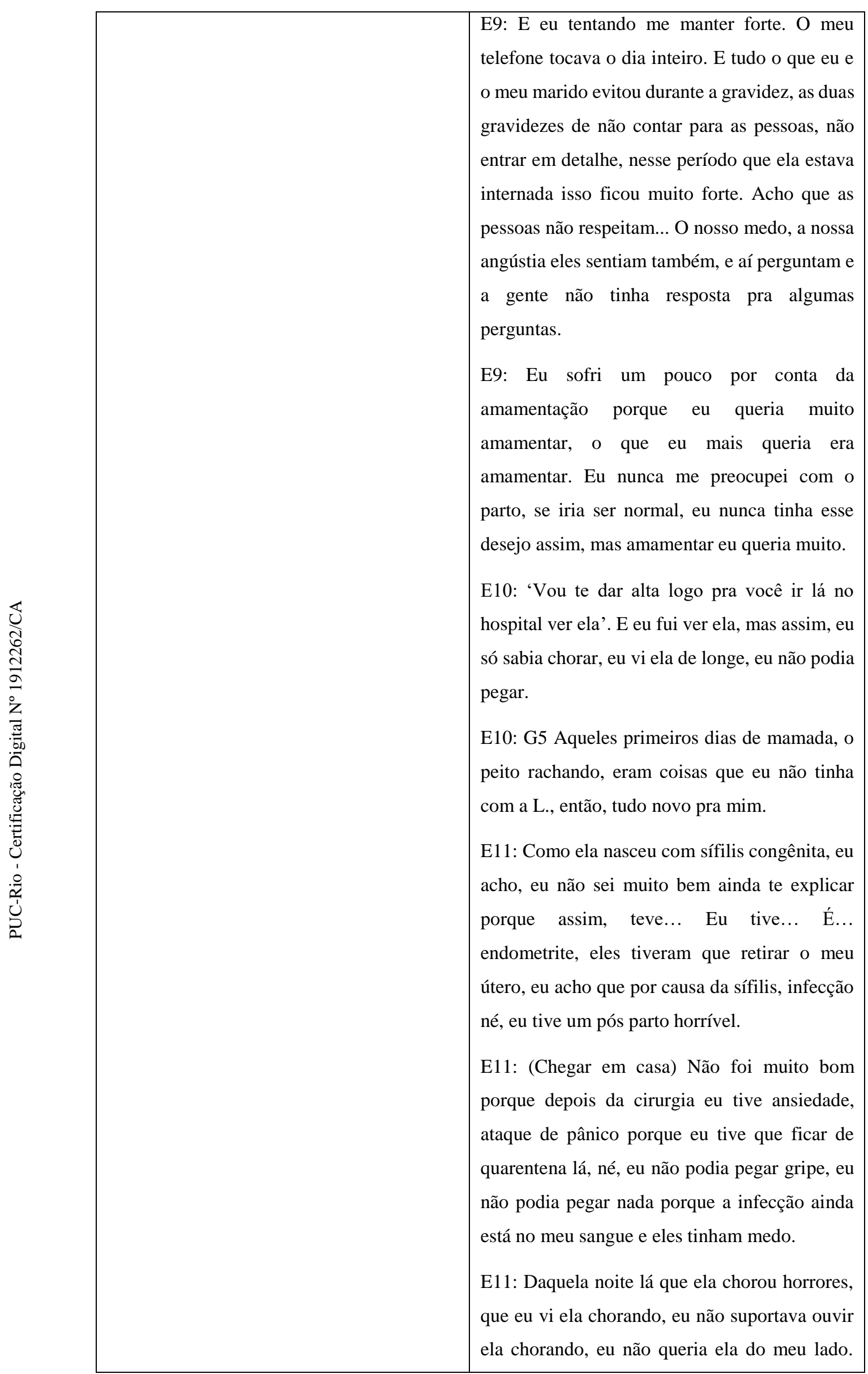




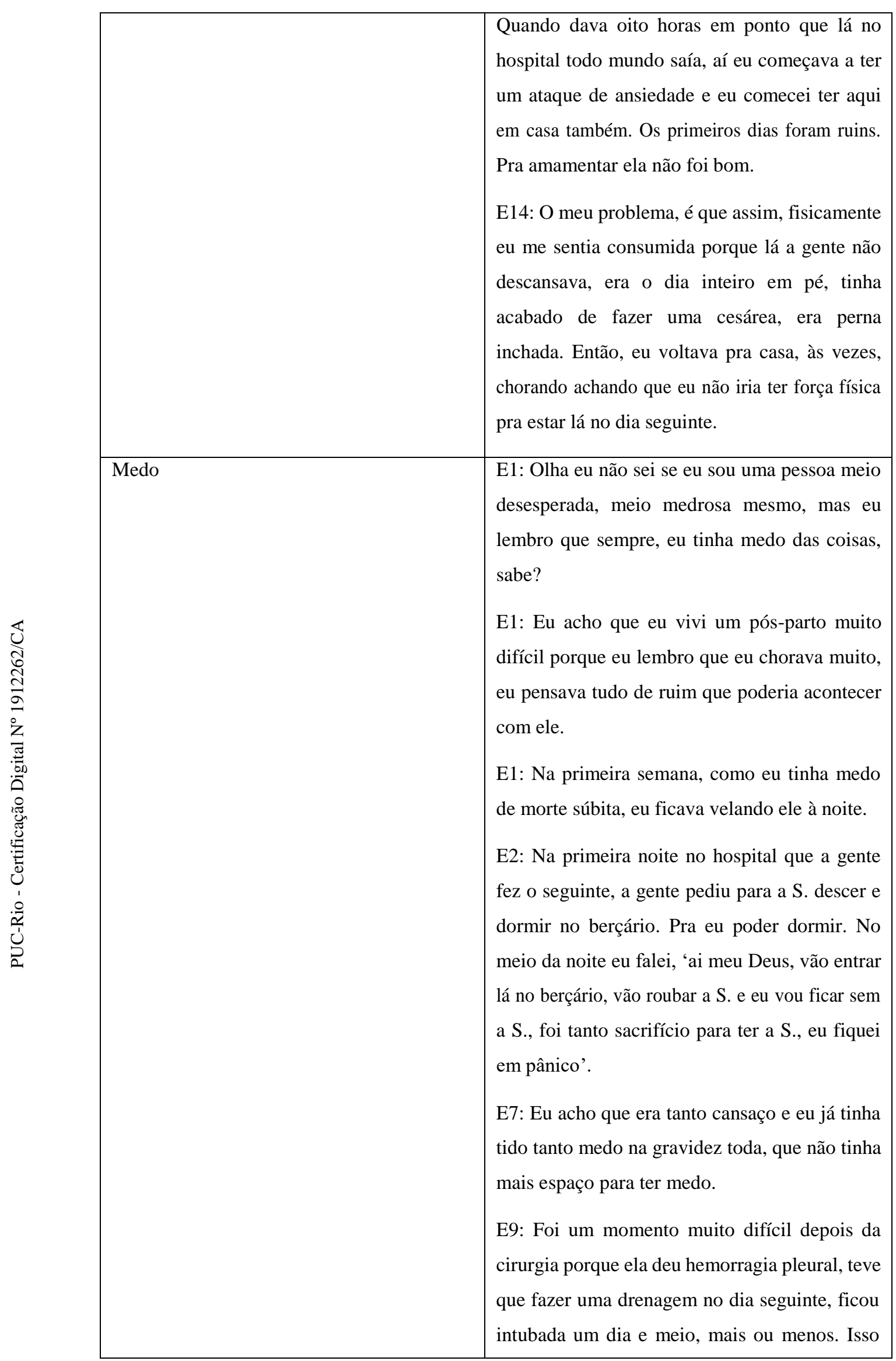




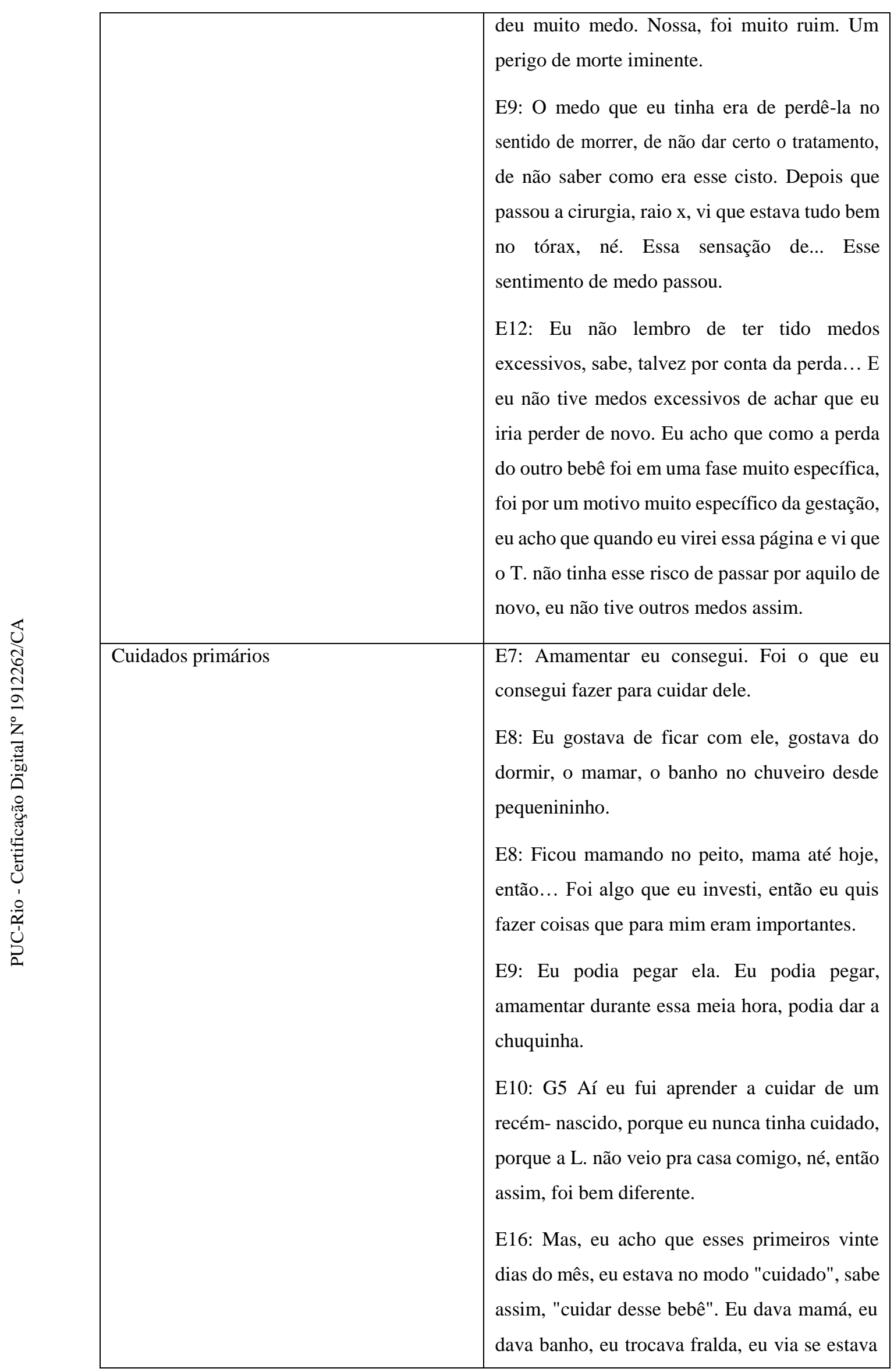




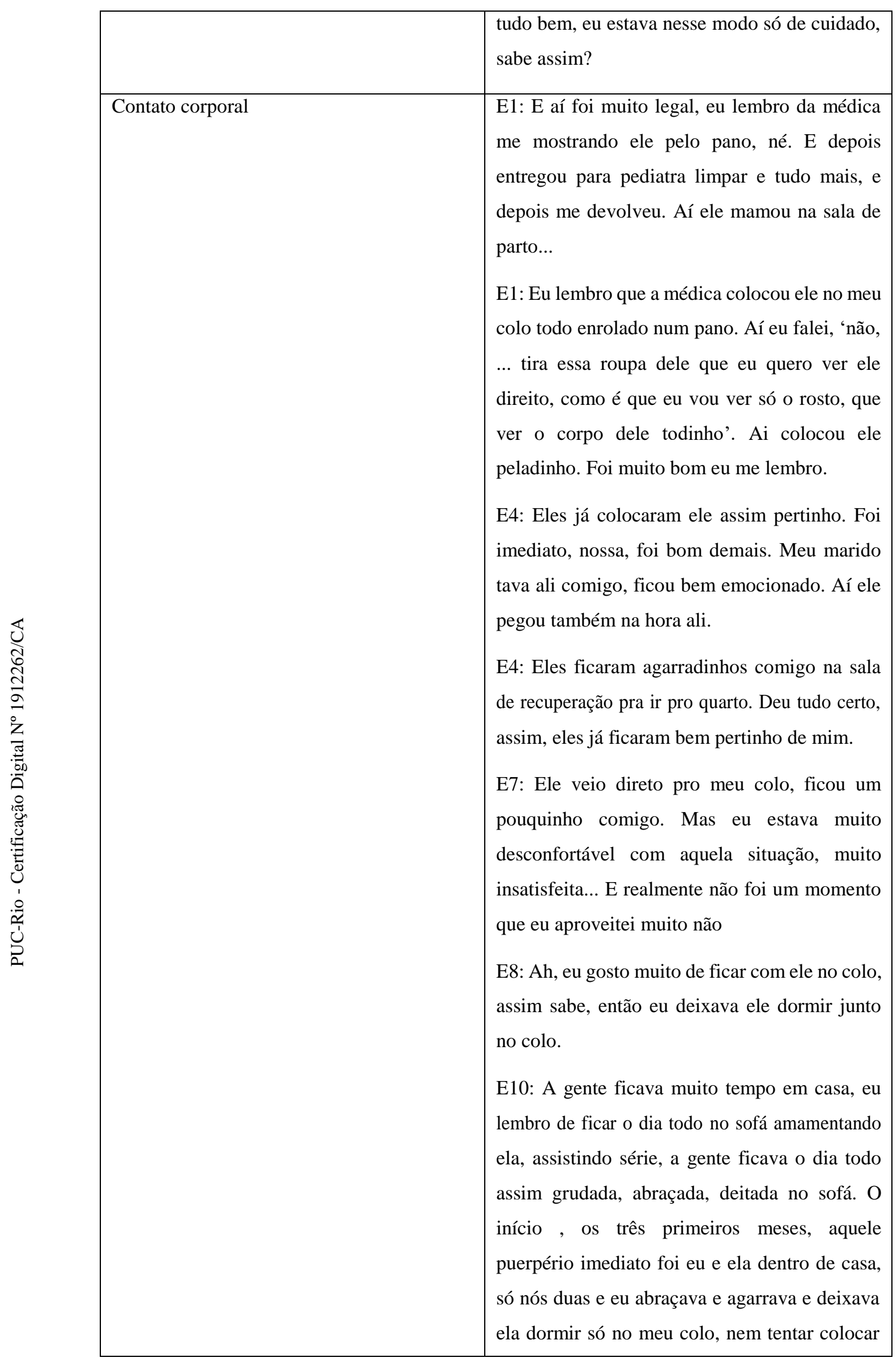




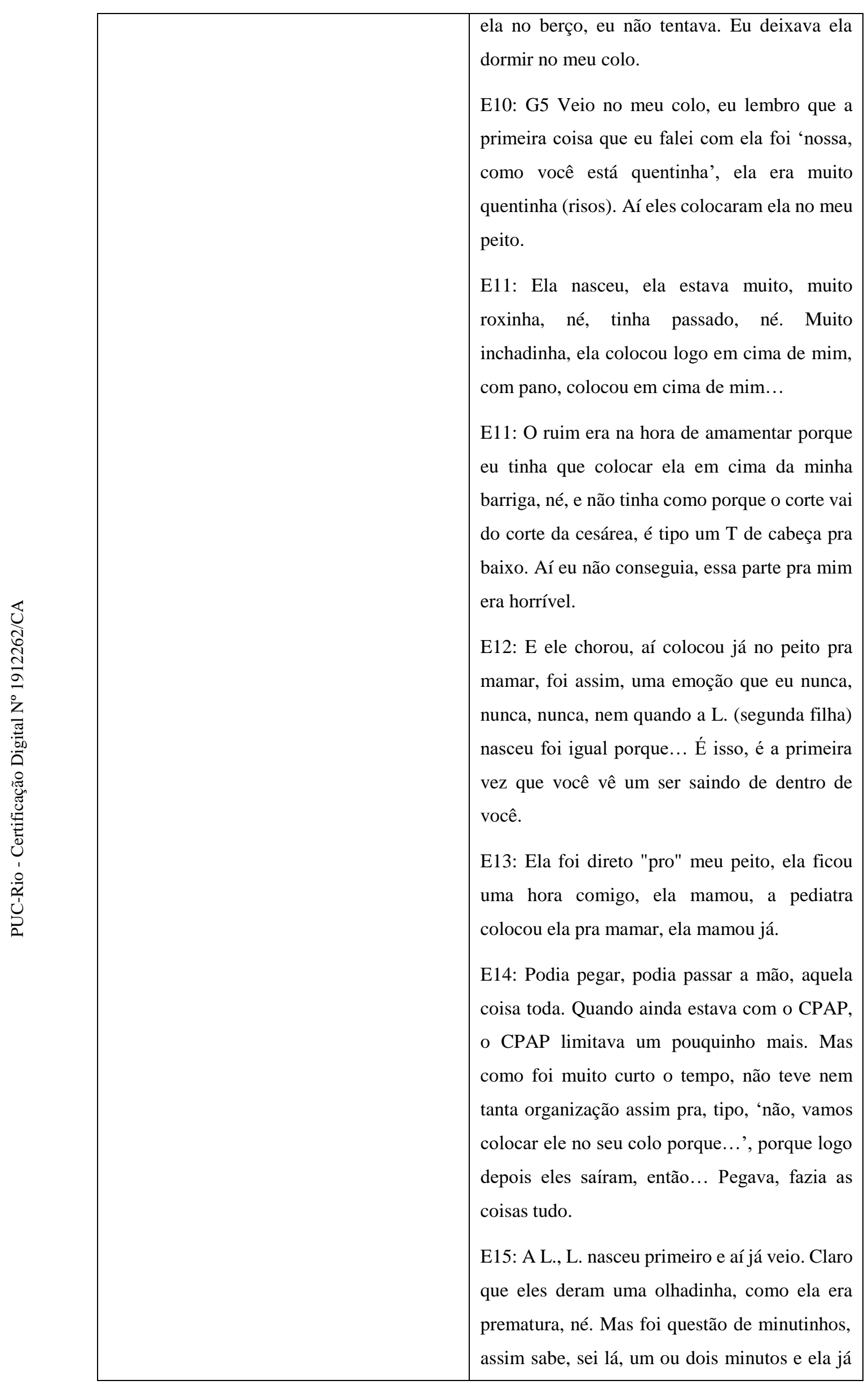




\begin{tabular}{|c|c|}
\hline & $\begin{array}{l}\text { estava comigo. Aí, depois nasceu o F., a mesma } \\
\text { coisa também, respirando, chorou, então não } \\
\text { precisou ser intubado nem nada. } \\
\text { E16: Ela veio para o meu colo, eu fiquei } \\
\text { chorando conversando com ela e aí, ela parou } \\
\text { de chorar ouvindo minha voz. } \\
\text { E17: Ele dormia mamando no meu peito e era } \\
\text { uma delícia. Até hoje ele dorme comigo na } \\
\text { cama, ele até os três meses ele dormia no meu } \\
\text { colo, mamando, assim. Eu dormia no sofá com } \\
\text { ele no meu colo e ele vinha colocava a boquinha } \\
\text { no peito e seguia mamando, era muito } \\
\text { bonitinho. Mas enfim, eu queria ficar muito } \\
\text { grudada nele, acho que é por isso. Ele acordava } \\
\text { muito, eu acordava muito também. Aí, eu falei } \\
\text { "cara, eu vou começar a dormir com ele no meu } \\
\text { colo porque aí quando ele quiser mamar, ele já } \\
\text { desce o rosto para o peito e eu não preciso } \\
\text { acordar" } \\
\text { E17: Eu gosto muito de dar beijinho nele, no } \\
\text { cangote que ele adora, ele dá aquele risinho de } \\
\text { criança. }\end{array}$ \\
\hline Trocas face-a-face & $\begin{array}{l}\text { E4: O momento mais mágico pra mim era a } \\
\text { amamentação, porque eu sempre assim, eu } \\
\text { tenho uma coisa muito do olhar. Então eu } \\
\text { olhava muito. } \\
\text { E5: A questão da amamentação é uma interação } \\
\text { muito forte para mim. Quando a gente começa } \\
\text { a amamentar e vê ela te olhando ali, ela parava, } \\
\text { às vezes, e ficava olhando... Acho que essa } \\
\text { interação foi a mais forte para mim. }\end{array}$ \\
\hline Estimulação por objeto & $\begin{array}{l}\text { E1: Sempre coloquei música } \\
\text { E6: Sempre gostei de nenezinho, assim, pra } \\
\text { mim, até oito, nove meses. Eu tinha todos os } \\
\text { aplicativos que uma mãe pode ter, pode achar } \\
\text { na internet. Então me avisava lá, três semanas, } \\
\text { quatro semanas, cinco semanas, ia falando } \\
\text { como é que tinha que ser, o que tinha que }\end{array}$ \\
\hline
\end{tabular}




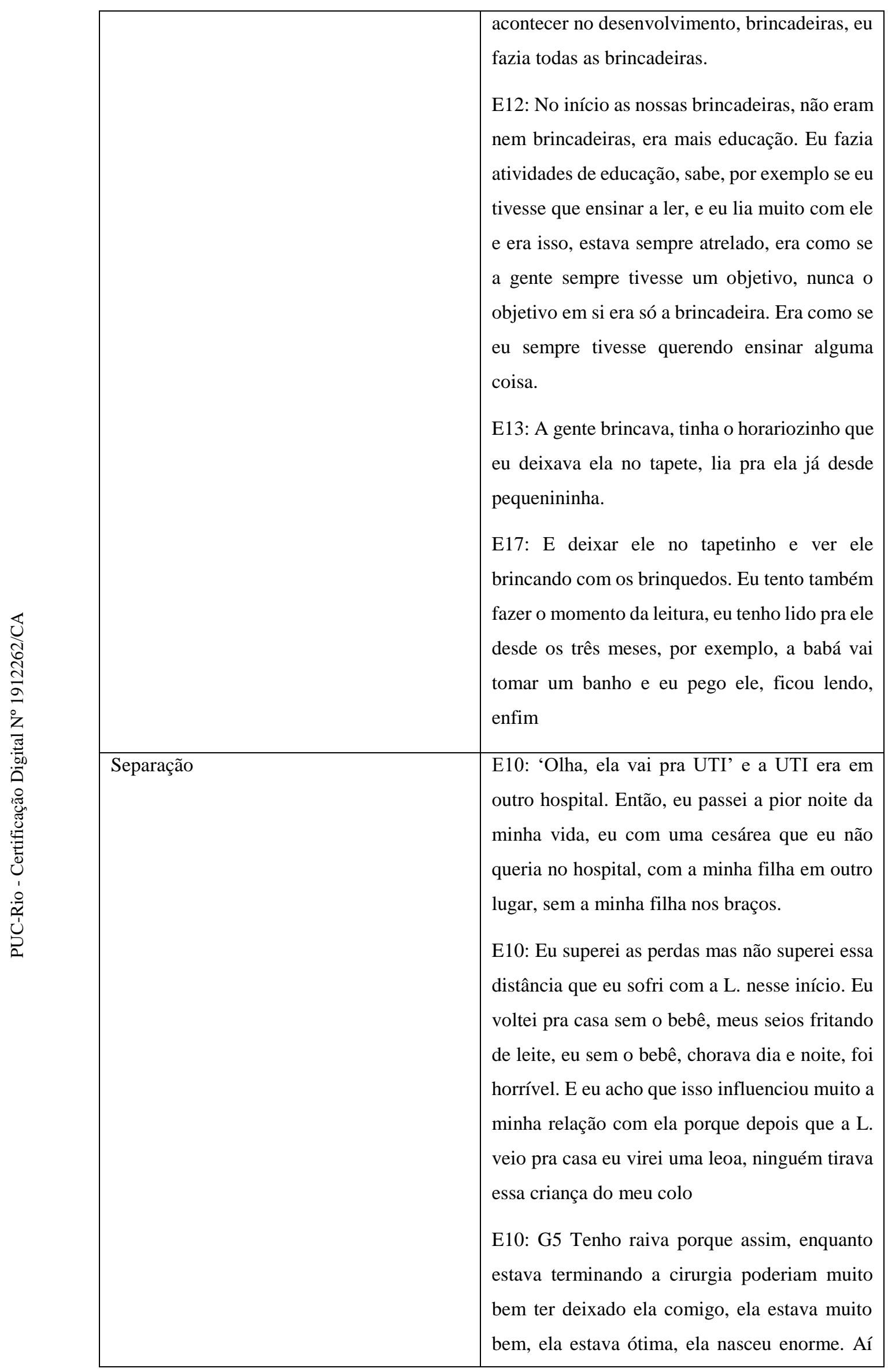




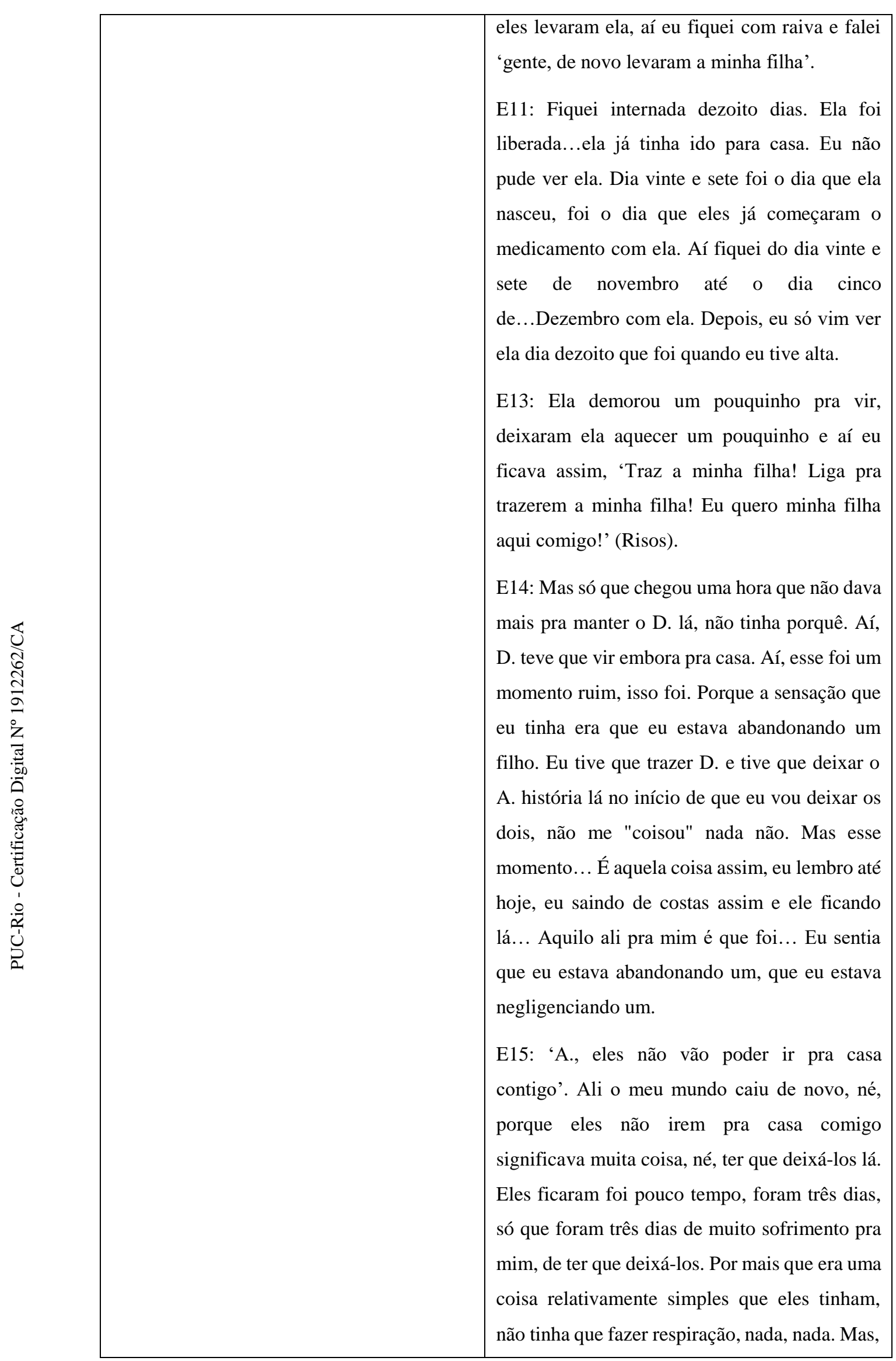




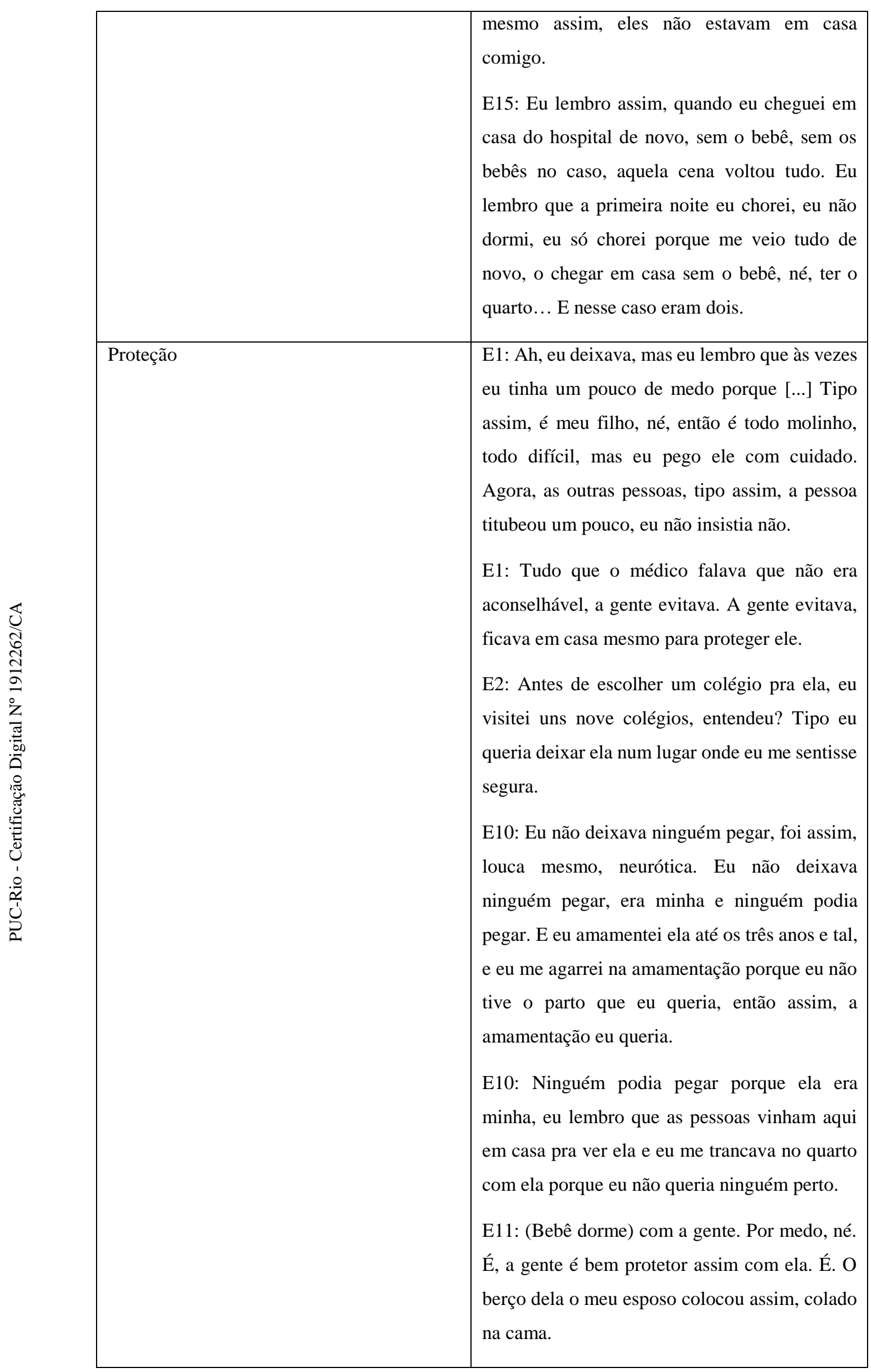




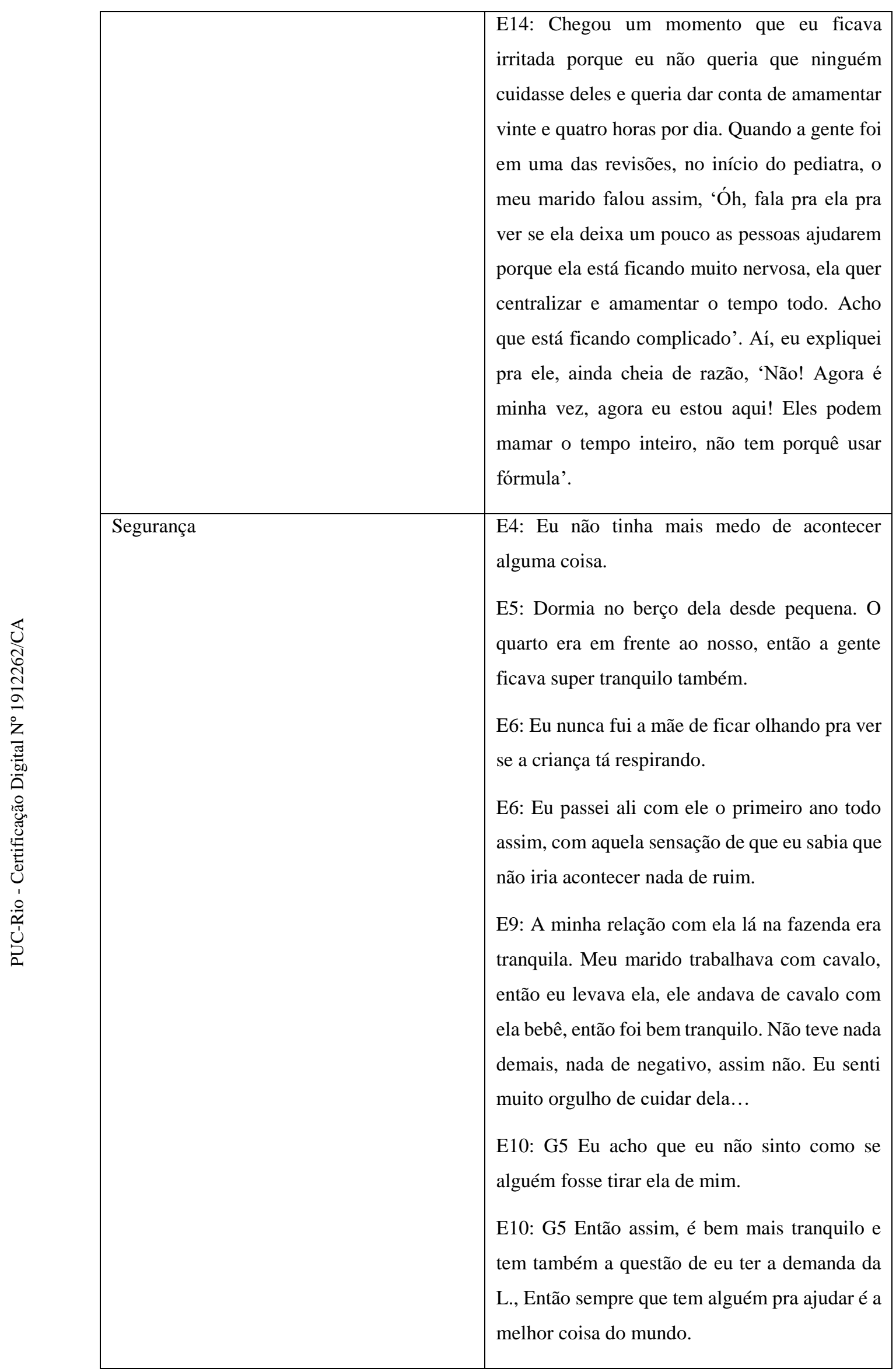




\begin{tabular}{|c|c|}
\hline & $\begin{array}{l}\text { E13: Então, eu não tinha essa coisa de 'Ai, meu } \\
\text { Deus, ela é parte de mim', então ninguém podia } \\
\text { encostar. Eu não tive isso, tanto que na } \\
\text { maternidade ela foi pro colo da minha mãe, foi } \\
\text { pro colo do meu pai, minhas amigas foram } \\
\text { visitar e foi pro colo. } \\
\text { E13: Acho que é importante ela me ter, mas } \\
\text { acho que é também importante ela criar laços } \\
\text { com outras pessoas, acho que é importante ela } \\
\text { ter uma rede. Eu não queria ter essa sensação de } \\
\text { que só eu podia e fazia. } \\
\text { E16: Assim, eu estava muito feliz, muito } \\
\text { realizada. Mas eu acho que eu ainda estava } \\
\text { assimilando tudo, sabe, 'Agora deu certo. Eu } \\
\text { posso me apegar'. }\end{array}$ \\
\hline Insegurança & $\begin{array}{l}\text { E1: Me sentia muito insegura ainda para } \\
\text { algumas coisas. } \\
\text { E2: Eu acho que coisas naturais, mas por } \\
\text { exemplo, eu não deixaria ela com uma babá. } \\
\text { E2: Muito, só eu e ela, só eu e ela. } \\
\text { E5: Eu ficava muito receosa de deixa-la, às } \\
\text { vezes, com meu marido. E olha que ele é super } \\
\text { dedicado, super paizão e tal. Mas tinha muito } \\
\text { essa ligação minha com ela e vice-versa. } \\
\text { E6: Meio dia ele dormiu no quarto dele, no meio } \\
\text { da noite eu peguei. A gente botou um berço lá } \\
\text { do lado da cama da gente. } \\
\text { E7: Eu não saía sozinha, eu tinha medo de sair } \\
\text { sozinha porque justamente por estar um tempo } \\
\text { assim em casa, eu não me sentia segura. Parece } \\
\text { que a minha cabeça não funcionava direito. } \\
\text { E9: Ela nunca foi de acordar a noite, nunca me } \\
\text { deu trabalho, acordava uma vez só pra mamar. } \\
\text { Mas ela mexia, aí eu olhava pro lado, via se ela } \\
\text { estava precisando de alguma coisa. Eu me sentia } \\
\text { mais segura, eu e meu marido. E aí, até hoje ela } \\
\text { dorme no berço ao lado da nossa cama. }\end{array}$ \\
\hline
\end{tabular}




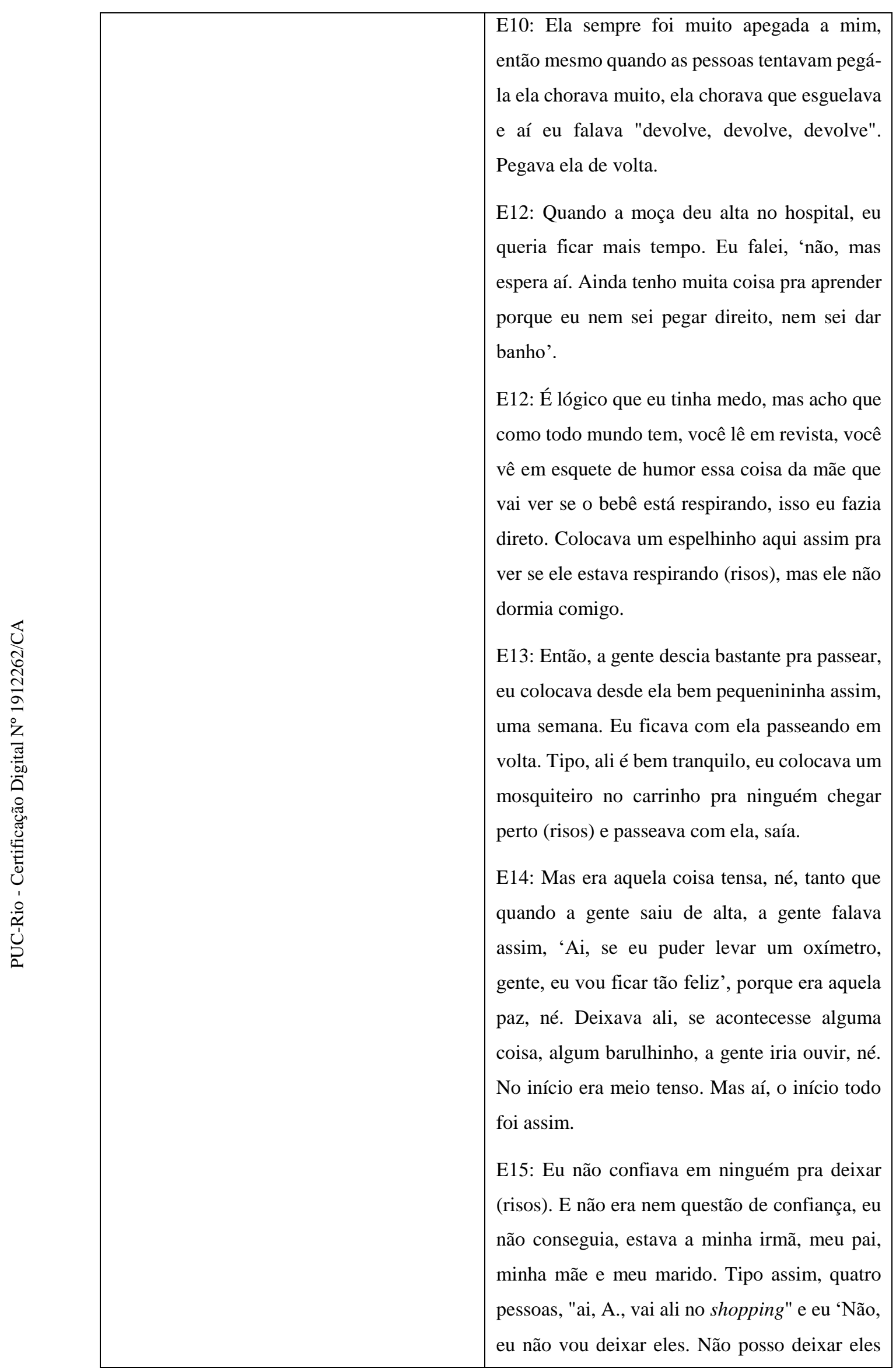




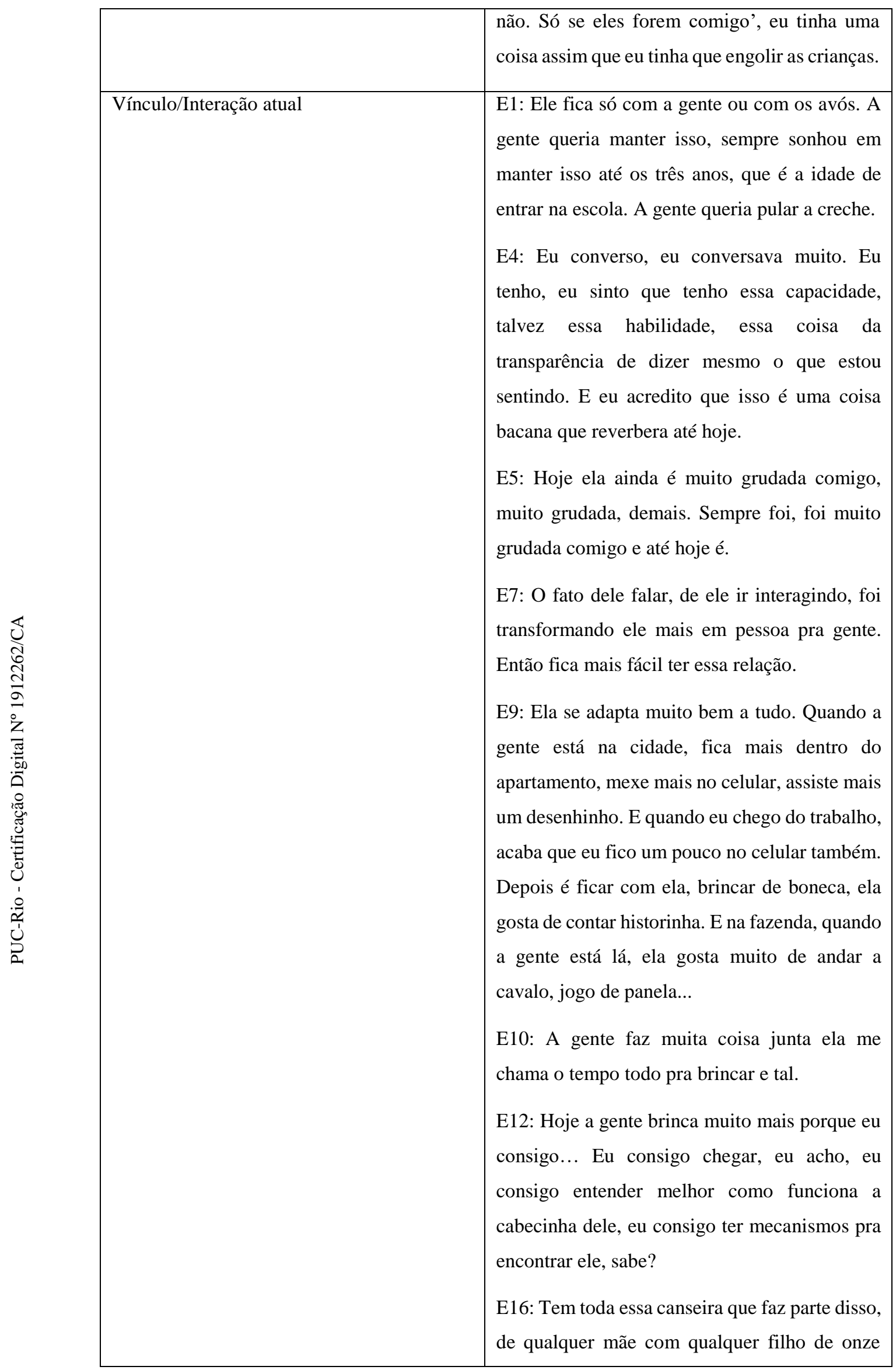




\begin{tabular}{|l|l|}
\hline & $\begin{array}{l}\text { meses. Mas eu não vejo que eu amo menos ela } \\
\text { ou que eu tenho medo de amar. }\end{array}$ \\
\hline
\end{tabular}

Ao descreverem as expectativas e primeiras interações com os bebês no momento do nascimento, o medo seguia presente. "No dia do parto eu tremia tanto que falei, "ela vai nascer morta, vai acontecer alguma coisa" (E2). "Eu estava com tanto medo por estar em uma cirurgia e tão tensa com tudo, que não aconteceu aquela coisa esperada. Eu só consegui perguntar se estava tudo bem, se estava tudo bem comigo, se estava tudo bem com ele" (E7).

E3 descreve o seu receio de trazer a história anterior para a filha que estava nascendo, "Eu fiquei com muito receio de trazer as coisas para cá, pra (bebê), então assim, quando ela nasceu eu falei, 'acabou, é uma outra vida, uma outra pessoa'. Mesmo recém-nascido. Ninguém trazia essa questão e eu acho que as poucas vezes que trouxeram eu cortei. Seria muito ruim vincular uma coisa com a outra. Acho que teria consequências muito graves. De fazer uma transferência qualquer ou de achar que ela não foi querida porque eu deveria ter encerrado a maternidade no outro e não encerrei, sabe? É inconcebível para mim esse tipo de coisa”. O incômodo aqui descrito vai ao encontro da ideia de Rato (1998), que pondera que a experiência de perda de um bebê durante a gravidez ou logo após o parto, poderia trazer como repercussão a projeção de sua sombra sobre o que aconteceria no futuro. Para a autora, a criança que chega após a perda encontra-se em uma situação difícil, uma vez que será confrontada com o bebê imaginário, podendo até ser confundida com o bebê morto. Parece ser isso o que a entrevistada não deseja para sua filha, não quer que as histórias sejam confundidas ou sobrepostas, ressaltando esse ponto para si mesma e para os outros.

Apesar dos relatos de que a chegada do bebê trouxe um profundo alívio para as mães, como descrevem E17 "Foi lindo (voz de choro), nossa... Foi lindo! Ele é perfeito, ele é perfeito! Ai, meu Deus, ele veio e eu nem acreditava. Eu chorava porque eu não acreditava que eu estava de novo conseguindo pegar ele, aí a diferença quando você perguntou, 'você pegou o G.?', eu não peguei o G., né, o E. eu realmente peguei” e E12: "Acho que foi realmente esse nascimento de alívio de concretização. Aquele alívio, aquela felicidade absurda", também houve narrativas de dificuldades nas interações iniciais. Al et al (2016) referem que mães que vivenciam o luto perinatal podem perceber os bebês que chegam após a perda como 
menos ideais do que as mães que não tiveram perda gestacional ou neonatal, assim como também podem identificar mais problemas em relação a questões de sono, choro e alimentação do que mães que não vivenciaram perdas. E3 e E4 falam de suas dificuldades relacionadas ao choro intenso de seus bebês "Ele chorava muito, ele tinha muita cólica até os três meses. Então, às vezes eu me irritava com o choro dele, não tinha muita paciência. Um choro incessante que, às vezes era difícil parar, me incomodava". E3 também destaca a questão do choro, porém salienta que sua falta de paciência não tinha a ver com a gravidez anterior, em que perdeu seu bebê no final da gestação. "Não foi fácil em nada, assim. É porque eu tive uma paciência de Jó. E eu não sei, acho que não foi nada a ver com a outra gravidez. Independente do que aconteceu historicamente, eu não acho que isso tem a ver diretamente com (a bebê). Mas, assim, ela era um bebê que chorava muito nos primeiros meses de vida”. E1 pontua sua dificuldade no processo de amamentação, mas também todo seu investimento: “A amamentação também foi difícil para mim no início, mas eu queria fazer tudo, não queria desistir de nada. Fui até meio radical com algumas coisas'.

Durante as entrevistas, algumas mães referiram comportamentos de superproteção em relação aos seus bebês. Para Al et al (2016), os comportamentos de superproteção podem surgir tanto da Síndrome do Bebê de Substituição, descrita por Cain e Cain (1964) como na Síndrome da Criança Vulnerável, referida por Green e Solnit (1964). E1 afirma que: "Tudo que o médico falava que não era aconselhável, a gente evitava. A gente evitava, ficava em casa mesmo para proteger ele". "Eu não deixava ninguém pegar, foi assim, louca mesmo, neurótica. Eu não deixava ninguém pegar, era minha e ninguém podia pegar. E eu amamentei ela até os três anos e tal, e eu me agarrei na amamentação porque eu não tive o parto que eu queria, então assim, a amamentação eu queria”. (E10). E14 descreve que sua superproteção e presença constantes eram uma tentativa de dar conta de seus bebês gêmeos o dia inteiro: "Chegou um momento que eu ficava irritada porque eu não queria que ninguém cuidasse deles e queria dar conta de amamentar vinte e quatro horas por dia". Na Síndrome do Bebê de Substituição, de acordo com Cain e Cain (1964), a mãe, de maneira inconsciente, idealiza o bebê perdido e faz comparações com o novo bebê. Segundo os autores, os comportamentos controladores são uma tentativa de conter os sentimentos agressivos. Na Síndrome da Criança Vulnerável (Green e Solnit, 1964) os comportamentos de controle da mãe estão possivelmente 
relacionados à percepção da criança como mais frágil à preocupação da mãe com relação a possíveis doenças futuras e morte. E11: “(Bebê dorme) com a gente. Por medo, né. É, a gente é bem protetor assim com ela. É. O berço dela o meu esposo colocou assim, colado na cama".

Nos discursos das mães, a insegurança em relação à maternidade, a dificuldade de confiar os filhos aos cuidados de outras pessoas e o sentimento de que só elas sabiam cuidar foram frequentes. E15 relata: "Eu não confiava em ninguém pra deixar (risos). E não era nem questão de confiança, eu não conseguia, estava a minha irmã, meu pai, minha mãe e meu marido. Tipo assim, quatro pessoas, 'ai, A., vai ali no shopping' e eu 'Não, eu não vou deixar eles. Não posso deixar eles não. Só se eles forem comigo', eu tinha uma coisa assim que eu tinha que engolir as crianças”. E5, apesar de perceber o marido como bom pai, também tinha dificuldades na separação e acreditava que a filha só ficava bem com ela: "Eu ficava muito receosa de deixá-la, às vezes, com meu marido. E olha que ele é super dedicado, super paizão e tal. Mas tinha muito essa ligação minha com ela e viceversa." E10 descreve a sua ligação com a filha: "Ela sempre foi muito apegada a mim, então mesmo quando as pessoas tentavam pegá-la ela chorava muito, ela chorava que esgoelava e aí eu falava 'devolve, devolve, devolve'. Pegava ela de volta".

A relação de apego é construída a partir dessa interação, que nas falas dessas mães, parece ter pouco espaço para terceiros. De acordo com Bowlby (2002) algumas condições contribuem para o desenvolvimento do apego a uma figura específica, tais como, a sensibilidade dessa figura para responder aos sinais do bebê e a quantidade e natureza das interações entre os componentes dessa dupla. Ao longo do desenvolvimento, é possível perceber que a mãe passa a esperar e perceber, de modo típico, os comportamentos do bebê, assim como a criança também passa a aguardar e receber, de modo típico, as interações com a mãe. Se por um lado a presença constante e dedicada fortalece o vínculo, por outro, pode haver pouco espaço para a presença de terceiros e para um maior movimento exploratório do bebê. Compreende-se que a mãe é figura principal nas interações iniciais, porém, cabe aqui pontuar que a experiência prévia de perda parece influenciar no comportamento de cuidar da mãe.

O medo intenso esteve presente em diversos momentos nas narrativas das mães sobre as interações iniciais, não apenas no momento do nascimento dos bebês. 
"Eu acho que eu vivi um pós-parto muito difícil porque eu lembro que eu chorava muito, eu pensava tudo de ruim que poderia acontecer com ele" (E1); "No meio da noite eu falei, 'ai meu Deus, vão entrar lá no berçário, vão roubar a S. e eu vou ficar sem a S., foi tanto sacrifício para ter a S., eu fiquei em pânico"” (E2); "Foi um momento muito difícil depois da cirurgia porque ela deu hemorragia pleural, teve que fazer uma drenagem no dia seguinte, ficou intubada um dia e meio, mais ou menos. Isso deu muito medo. Nossa, foi muito ruim. Um perigo de morte iminente" (E9).

Algumas mães referiram as preocupações e inseguranças do marido em relação ao bebê. E14, relata que, após a alta de seus bebês da UTI neonatal, ela e o marido sentiam-se muito alertas a qualquer ameaça: "Mas era aquela coisa tensa, né, tanto que quando a gente saiu de alta, a gente falava assim, 'Ai, se eu puder levar um oxímetro, gente, eu vou ficar tão feliz', porque era aquela paz, né. Deixava ali, se acontecesse alguma coisa, algum barulhinho, a gente iria ouvir, né. No início era meio tenso. Mas aí, o início todo foi assim”. E6 descreve que ela e o marido não conseguiram dormir afastados do filho: "Meio dia ele dormiu no quarto dele, no meio da noite eu peguei. A gente botou um berço lá do lado da cama da gente.” E9 também fala sobre a dificuldade do casal de se afastar da filha à noite, mesmo que não houvesse qualquer necessidade específica de proximidade. "Ela nunca foi de acordar à noite, nunca me deu trabalho, acordava uma vez só pra mamar. Mas ela mexia, aí eu olhava pro lado, via se ela estava precisando de alguma coisa. Eu me sentia mais segura, eu e meu marido. E aí, até hoje ela (próximo de completar 2 anos) dorme no berço ao lado da nossa cama."

Apesar de as questões acerca da construção de vínculo e das interações sociais serem ainda hoje muito focadas na mãe, Bussab (2000) menciona que autores da teoria do desenvolvimento evolucionista têm abordado a importância da convivência e não só do parentesco como propiciador de vinculações afetuosas e significativas entre os pais e seus bebês. E13 fala da conexão entre pai e bebê desde o primeiro exame de imagem: “Assim, no minuto que a gente viu o palitinho, ele já estava conectado, assim, com ela. Já estava presente mesmo longe (pai estava morando em outra cidade). A gente fazia face time e ele falava comigo no viva-voz e ela mexia toda na barriga, assim sabe? Então assim, já era uma coisa muito forte entre os dois, sabe?". E3, por outro lado, fala da dificuldade nas interações iniciais entre pai e filha, por conta do processo de luto vivenciado por ele: "Eu era a pessoa 
mais próxima dela porque o meu marido teve dificuldade de interagir muito com ela no começo". De acordo com Nunes, Fernandes e Vieira (2007), a participação dos pais é muito significativa nos cuidados parentais não só na relação direta com o bebê, mas também como suporte para a mãe exercer a maternagem. Bowlby (1988) enfatiza que cuidar de bebês e crianças pequenas não é tarefa para uma pessoa só. O trabalho pode até ser bem feito por uma pessoa só, mas esse cuidador principal ficará exausto e precisará de assistência.

Quando nascem, mesmo que a termo, os bebês humanos são considerados prematuros e necessitam de um investimento de cuidados significativo. De acordo com Keller (2002), os bebês têm um repertório de comportamentos que aciona no outro o cuidado, assim como os cuidadores também possuem predisposições que possibilitam a interação e o cuidado dos bebês. Bowlby (2002) também aborda a questão da interrelação entre os comportamentos da mãe e da criança. O bebê responde à forma como a mãe interage com ele, responde ao seu contato, mas a mãe também é afetada pela forma como o bebê interage com ela. A narrativa de E16 exemplifica a construção do vínculo afetivo com o bebê baseada no cuidado e no atendimento às necessidades do recém-nascido "No começo eu não senti aquele amor incondicional que todo mundo fala que sente. (...) E depois, com o passar do tempo que eu fui criando um vínculo mais afetivo e tudo. Eu cuidava, não tive rejeição, não tive nada por ela. Cuidava, me envolvia com ela e tudo, só que o meu vínculo com ela foi sendo construído com o passar dos dias... Sabe assim?”. O comportamento do bebê aciona na mãe enlutada o comportamento de cuidar e pode ser motor para a construção do vínculo afetivo. Bowlby (2002) destaca como característica essencial das interações iniciais a capacidade de estabelecer uma harmonia ou adaptação mútua entre os ritmos de comportamento, além da regulação da atenção conjunta.

Diferentes modos de interagir foram identificados nos discursos das mães. De acordo com Keller (2002), a parentalidade acontece através dessa interação e compreende a motivação para os cuidados com o bebê através de atenção específica, consolo e conforto em momentos de maior desgaste. Além disso, a parentalidade tem como objetivo responder adequadamente aos sinais de comunicação, além de estimular o crescimento e o desenvolvimento. A autora descreve cinco sistemas parentais que organizam a parentalidade em conjuntos de 
comportamentos: "cuidados primários", "contato corporal”, "estimulação corporal", "estimulação por objeto" e "trocas face-a-face".

Os "cuidados primários" caracterizam-se pelo provimento das necessidades básicas do bebê (comida, abrigo, higiene) e representam a forma mais antiga de cuidados parentais e sua principal função é reduzir o estresse, mais do que dividir momentos agradáveis com o bebê. "Eu gostava de ficar com ele, gostava do dormir, o mamar, o banho no chuveiro desde pequenininho" (E8). Logo após o nascimento, a filha de E9 precisou ficar internada para se submeter a uma cirurgia e sentia que alimentá-la era o que podia fazer naquele primeiro momento "Eu podia pegar ela. Eu podia pegar, amamentar durante essa meia hora, podia dar a chuquinha”. E16 relata que nos primeiros dias de sua filha, sentia que só conseguia se dedicar a ela através de cuidados primários: "Mas, eu acho que esses primeiros vinte dias do mês, eu estava no modo 'cuidado', sabe assim, 'cuidar desse bebê'. Eu dava mamá, eu dava banho, eu trocava fralda, eu via se estava tudo bem, eu estava nesse modo só de cuidado, sabe assim?".

As entrevistas revelaram o "contato corporal" como principal sistema parental no cuidado com esses bebês nascidos após perdas perinatais. A importância desse contato foi narrada por algumas mães ao descreverem a interação logo após o nascimento. Eu lembro que a médica colocou ele no meu colo todo enrolado num pano. Aí eu falei, 'não... tira essa roupa dele que eu quero ver ele direito, como é que eu vou ver só o rosto, que ver o corpo dele todinho'. Aí colocou ele peladinho. Foi muito bom eu me lembro" (E1). "Eles já colocaram ele assim pertinho. Foi imediato, nossa, foi bom demais. (...) Eles ficaram agarradinhos comigo na sala de recuperação pra ir pro quarto. Deu tudo certo, assim, eles já ficaram bem pertinho de mim" (E4). "Ela veio para o meu colo, eu fiquei chorando conversando com ela e aí, ela parou de chorar ouvindo minha voz". A função psicológica do contato corporal consiste, segundo Keller (2002) na experiência do calor emocional e parece ser possível inferir que o contato corporal com o corpo vivo e quente do bebê foi muito significativo para essas mães. E10 descreve o primeiro contato com a filha: "Veio no meu colo, eu lembro que a primeira coisa que eu falei com ela foi 'nossa, como você está quentinha', ela era muito quentinha (risos). Aí eles colocaram ela no meu peito". E10 também descreve a interação com a filha em casa: "A gente ficava muito tempo em casa, eu lembro de ficar o dia todo no sofá amamentando ela, assistindo série, a gente ficava o dia todo assim grudada, 
abraçada, deitada no sofá. O início, os três primeiros meses, aquele puerpério imediato foi eu e ela dentro de casa, só nós duas e eu abraçava e agarrava e deixava ela dormir só no meu colo, nem tentar colocar ela no berço, eu não tentava". Ainda segundo Keller (2002), carregar o bebê junto ao corpo é, em muitas culturas, uma estratégia de proteção frente aos perigos e ameaças do ambiente. Para algumas entrevistadas, ao terem seus bebês vivos em seus braços, o que mais desejavam era protegê-los de toda e qualquer ameaça. E17 descreve momentos de amamentação, mas o que parece mais primordial é o contato corporal com o bebê: "Ele dormia mamando no meu peito e era uma delícia. Até hoje ele dorme comigo na cama, ele até os três meses ele dormia no meu colo, mamando, assim. Eu dormia no sofá com ele no meu colo e ele vinha colocava a boquinha no peito e seguia mamando, era muito bonitinho. Mas enfim, eu queria ficar muito grudada nele”. Uma das mães, apesar da ansiedade e expectativa pelo nascimento de seu bebê vivo para poder segurá-lo no colo e cuidar, sentiu-se tão frustrada em relação ao parto que não conseguiu aproveitar os primeiros momentos de contato físico: "Ele veio direto pro meu colo, ficou um pouquinho comigo. Mas eu estava muito desconfortável com aquela situação, muito insatisfeita... E realmente não foi um momento que eu aproveitei muito não” (E7).

Diferentes formas de "estimulação por objetos" foram referidas pelas mães, desde colocar música até utilizar todos os aplicativos disponíveis para saber qual era a melhor maneira de interagir com o bebê. "Eu tinha todos os aplicativos que uma mãe pode ter, pode achar na internet. Então me avisava lá, três semanas, quatro semanas, cinco semanas, ia falando como é que tinha que ser, o que tinha que acontecer no desenvolvimento, brincadeiras, eu fazia todas as brincadeiras" (E6). Para duas mães, tapetinho e livros foram identificados como objetos importantes na interação e estimulação: “A gente brincava, tinha o horariozinho que eu deixava ela no tapete, lia pra ela já desde pequenininha (E13); "Deixar ele no tapetinho e ver ele brincando com os brinquedos. Eu tento também fazer o momento da leitura, eu tenho lido pra ele desde os três meses, por exemplo, a babá vai tomar um banho e eu pego ele, ficou lendo, enfim" (E17). A estimulação por objeto está muito relacionada a atividades exploratórias e tem como função psicológica nutrir o sistema cognitivo, além de desengajar o bebê da dependência de relacionamentos sociais (Keller, 2002). E12 descreve as primeiras interações como momentos de aprendizagem de estímulo cognitivo: "No início as nossas brincadeiras, não eram 
nem brincadeiras, era mais educação. Eu fazia atividades de educação, sabe, era como se a gente sempre tivesse um objetivo, nunca o objetivo em si era só a brincadeira. Era como se eu sempre tivesse querendo ensinar alguma coisa".

Duas mães descreveram as "trocas face-a-face" como os momentos mais significativos da interação com seus bebês. Nas duas narrativas, o contato ocular mútuo estava atrelado à amamentação. "O momento mais mágico pra mim era a amamentação, porque eu sempre assim, eu tenho uma coisa muito do olhar. Então eu olhava muito" (E4).

“A questão da amamentação é uma interação muito forte para mim. Quando a gente começa a amamentar e vê ela te olhando ali, ela parava, às vezes, e ficava olhando... Acho que essa interação foi a mais forte para mim". Para Keller (2002), as trocas face-a-face são capazes de proporcionar ao bebê o sentimento de ser único e especial para aquele cuidador, além de também ser uma forma de compartilhar emoções positivas e se sentir relacionado a alguém.

\begin{tabular}{|c|c|}
\hline $\begin{array}{lccc}\text { Categorias de } & \text { Análises } & - \\
\text { TRANSFORMAÇÃO NA VIDA } & \end{array}$ & Informações obtidas \\
\hline & $\begin{array}{l}\text { E1: Eu acho que me tornei uma pessoa } \\
\text { totalmente diferente em vários aspectos, eu } \\
\text { consigo ser mais objetiva, eu tenho outro } \\
\text { objetivo de vida é outra prioridade. Minha } \\
\text { vontade é sempre voltar para casa pra estar com } \\
\text { ele, cuidar dele, ver se ele ficou bem. Eu fico } \\
\text { nervosa quando ele fica com alguém que não é } \\
\text { meu marido ou eu. }\end{array}$ \\
\hline & $\begin{array}{l}\text { E2: Primeiro, que ela só trouxe alegria pra gente. } \\
\text { Eu mudei completamente em relação ao meu } \\
\text { jeito de ser, eu sou muito mais tranquila. Eu era } \\
\text { uma pessoa que trabalhava que nem uma louca. } \\
\text { Hoje eu trabalho por freela, eu, eu, eu estudo o } \\
\text { que vou trabalhar. Eu penso se vai fazer sentido } \\
\text { pra mim aquilo. }\end{array}$ \\
\hline & $\begin{array}{l}\text { E3: Teve transformação com a maternidade em } \\
\text { si. O que ela me ensinou é que cada filho é um } \\
\text { filho. Eu entendo que (a bebê) foi a próxima que } \\
\text { nasceu depois dessa situação, mas sinceramente, } \\
\text { eu não acho que eu tenho nenhum }\end{array}$ \\
\hline
\end{tabular}




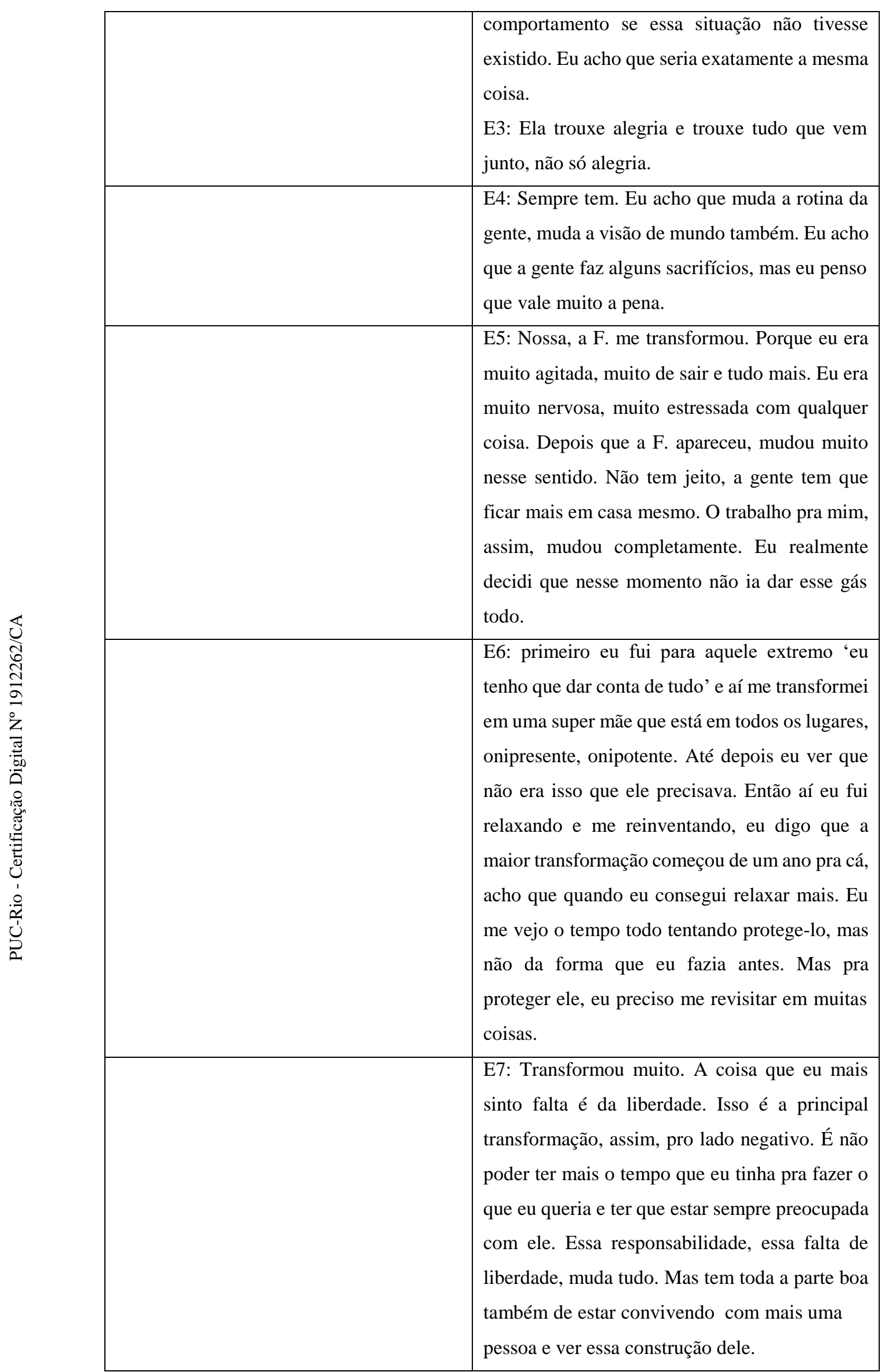




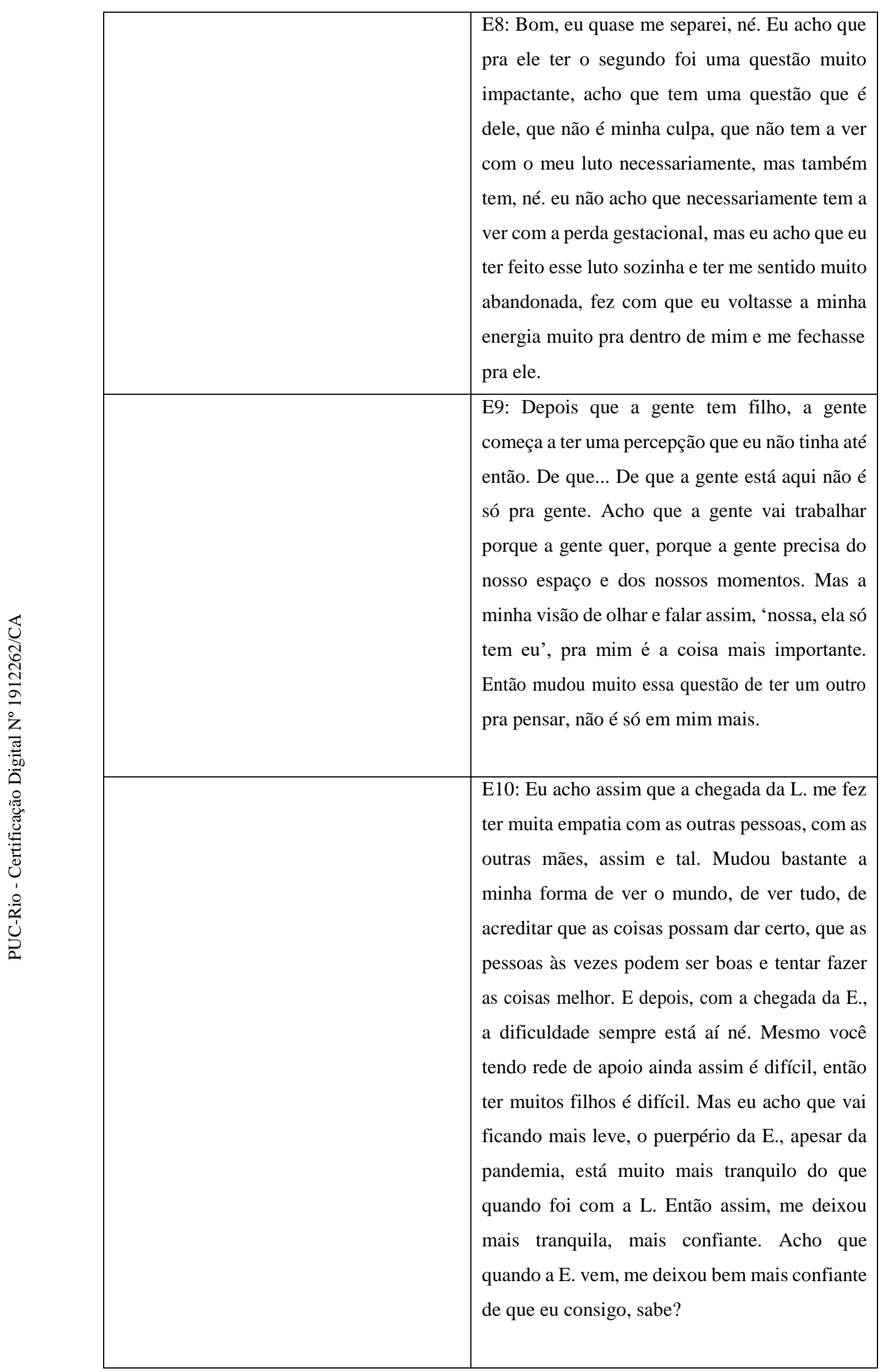




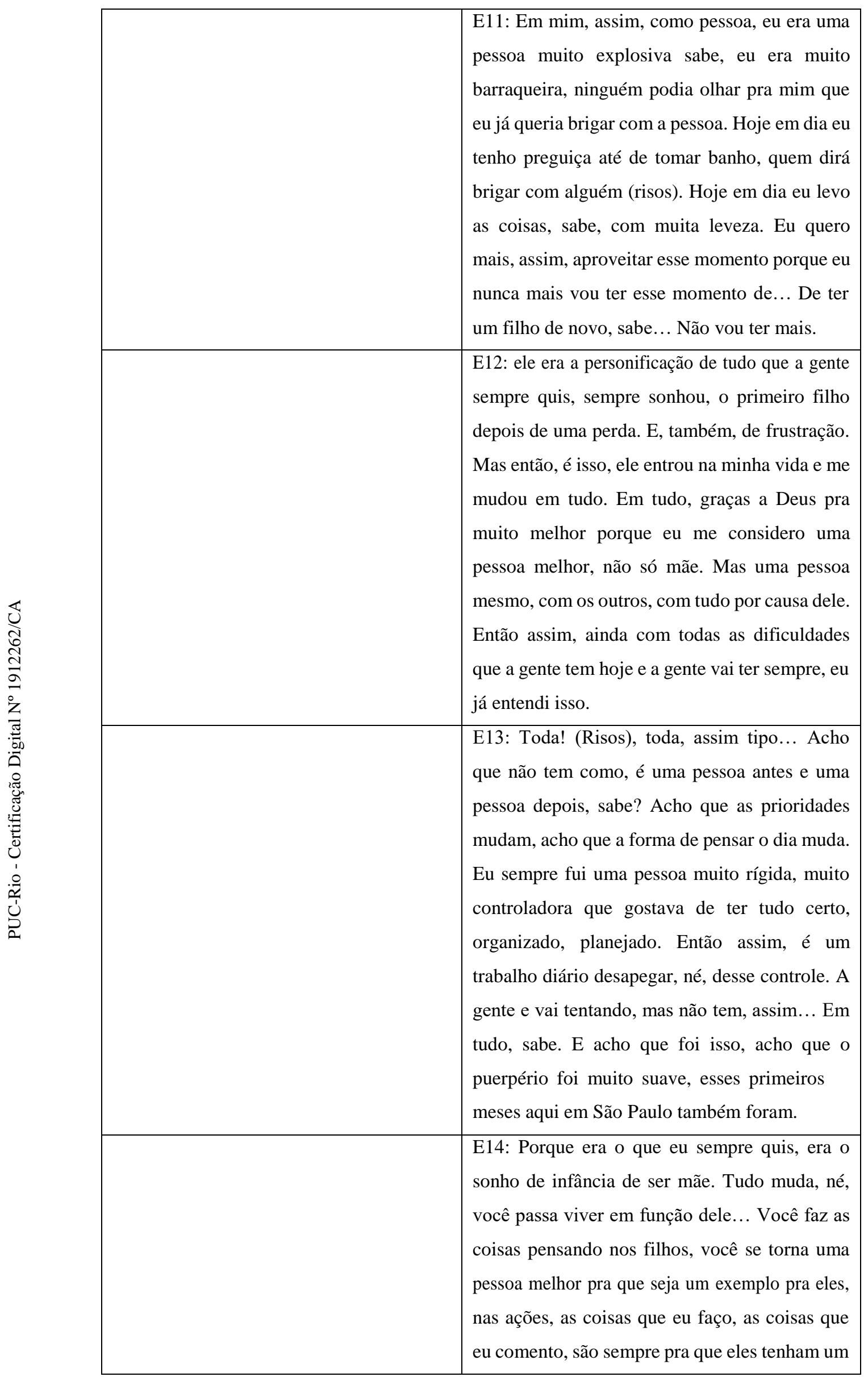




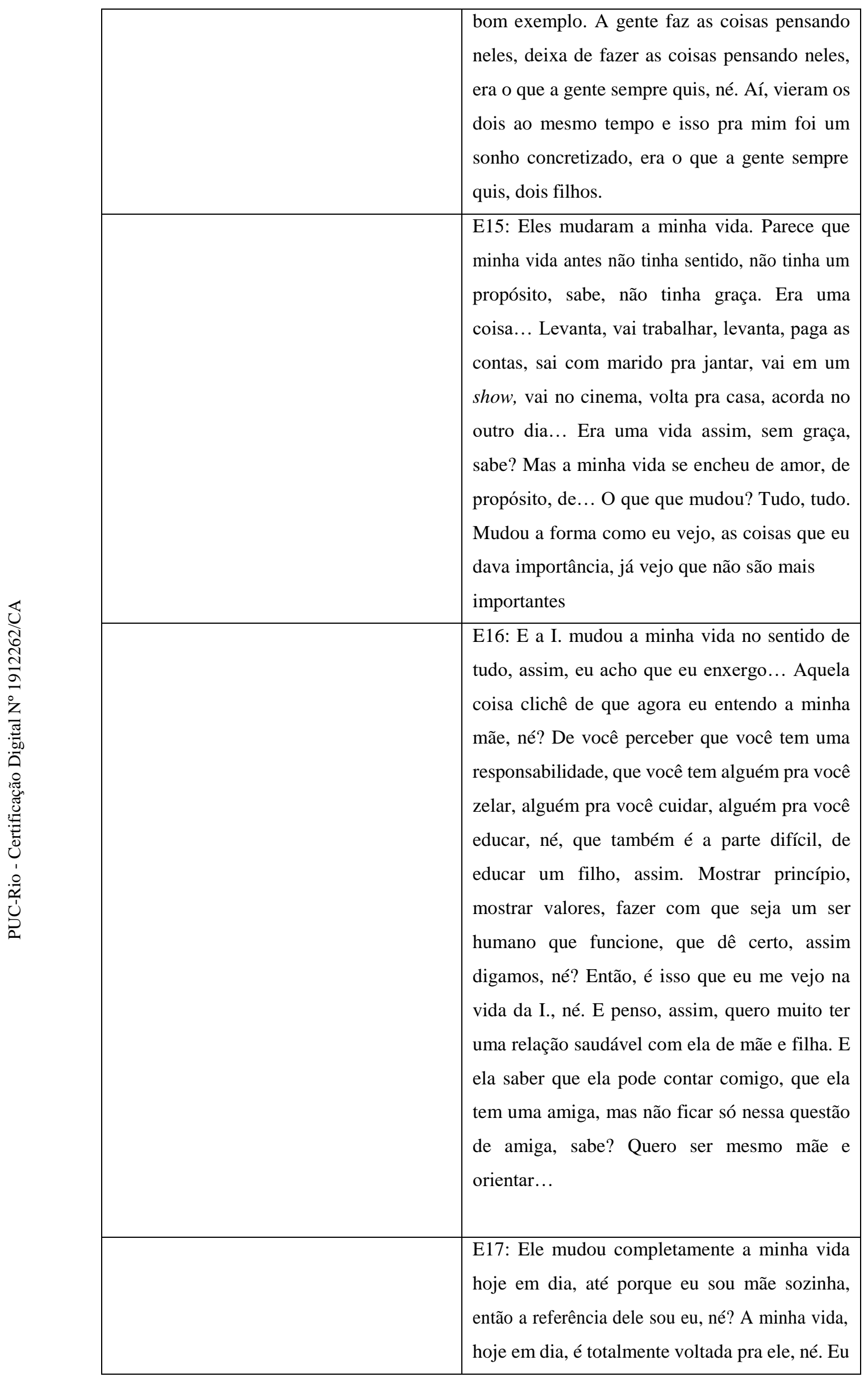




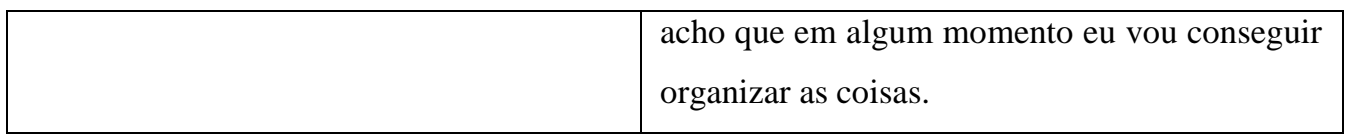

A chegada do novo bebê trouxe mudanças significativas na vida dessas mães. E17, mãe que decidiu, após a perda, ter uma produção independente, relata que "Ele mudou completamente a minha vida, hoje em dia, até porque eu sou mãe sozinha, então a referência dele sou eu, né? A minha vida, hoje em dia, é totalmente voltada pra ele, né. Eu acho que em algum momento eu vou conseguir organizar as coisas". A questão da responsabilidade da maternidade, foi referida por muitas mães como importante transformação. "Perceber que você tem uma responsabilidade, que você tem alguém pra você zelar, alguém pra você cuidar, alguém pra você educar, né, que também é a parte difícil, de educar um filho, assim. Mostrar princípio, mostrar valores, fazer com que seja um ser humano que funcione, que dê certo" (E16). "Tudo muda, né, você passa viver em função dele... Você faz as coisas pensando nos filhos, você se torna uma pessoa melhor pra que seja um exemplo pra eles, nas ações, as coisas que eu faço, as coisas que eu comento, são sempre pra que eles tenham um bom exemplo". (E15). "Mas a minha visão de olhar e falar assim, 'nossa, ela só tem eu', pra mim é a coisa mais importante. Então mudou muito essa questão de ter um outro pra pensar, não é só em mim mais" (E9). A questão da responsabilidade versus perda da liberdade é abordada por E7 "É não poder ter mais o tempo que eu tinha pra fazer o que eu queria e ter que estar sempre preocupada com ele. Essa responsabilidade, essa falta de liberdade, muda tudo. Mas tem toda a parte boa também de estar convivendo com mais uma pessoa e ver essa construção dele".

E12 refere que "ele era a personificação de tudo que a gente sempre quis, sempre sonhou, o primeiro filho depois de uma perda. E, também, de frustração. Mas então, é isso, ele entrou na minha vida e me mudou em tudo", assinalando que, apesar da profunda transformação, a chegada de um filho muito esperado também traz frustrações.

Também foi mencionada a mudança na personalidade a partir da chegada do filho. E11, que depois do nascimento de sua filha precisou retirar o útero relata que "Em mim, assim, como pessoa, eu era uma pessoa muito explosiva sabe, eu era muito barraqueira, ninguém podia olhar pra mim que eu já queria brigar com a pessoa. Hoje em dia eu levo as coisas, sabe, com muita leveza. Eu quero mais, 
assim, aproveitar esse momento porque eu nunca mais vou ter esse momento de... De ter um filho de novo, sabe... Não vou ter mais". A chegada de sua filha também impossibilita a chegada de outros filhos, o que para, para uma mulher jovem, tem repercussões importantes.

A superproteção e a o desejo de dar conta de tudo foram mencionados como mudanças trazidas pela chegada do filho "Primeiro eu fui para aquele extremo 'eu tenho que dar conta de tudo' e aí me transformei em uma super mãe que está em todos os lugares, onipresente, onipotente. Até depois eu ver que não era isso que ele precisava" (E6).

Em relação ao bebê arco-íris, foram poucas as menções ao termo. E15, ao contar sobre a descoberta da gravidez após a perda relata: "Eu perdi a N. em janeiro e em agosto eu já descubro uma nova gravidez. E, na semana do Dia dos Pais, eu vou fazer a primeira eco, o R. vai comigo e a gente descobre que são gêmeos! Dois bebês! E aí, eu fui do céu ao inferno, do inferno ao céu. Não sei te descrever o que eu senti na hora porque eram dois bebês arco-íris chegando!”. E10, após a realização da entrevista, envia para a pesquisadora uma foto da tatuagem com um arco-íris simbolizando o nascimento de seus bebês. E3, em contrapartida, questiona o conceito e diz que não concorda com sua utilização. "Tem esse conceito, né, baby rainbow. Eu não gosto do conceito porque ele amarra a criança ao histórico do que aconteceu, entendeu? Eu acho que cada um tem a sua história. Então ela não é rainbow baby porque teve uma perda antes, foge da história dela, entendeu? Acho que os caminhos são muito separados e eu prefiro que seja assim. Acho ruim vincular ao que aconteceu". Essa passagem vai ao encontro dos achados na pesquisa de Lee, Mc-Kenzie-McHarg e Horsch (2013), que apontam para a necessidade de muitas mães marcarem que o novo bebê não é um substituto do bebê morto. 


\section{9 \\ Considerações Finais}

Os filhos existem antes mesmo de sua chegada na vida das famílias. São a combinação de desejos e planos futuros, assim como desejo de continuidade dos pais. Quando ocorre uma perda gestacional ou neonatal, algo dos pais também é perdido, mesmo que não reconheçam. Perde-se um filho, mas também são perdidos desejos e expectativas.

Se antes acreditavam que engravidar e gestar era algo natural, a realização de um sonho, depois da perda esse processo passa a ser vivido com medo intenso e ansiedade, acompanhados pela sensação de constante ameaça. A maneira de lidar com a gravidez subsequente a uma (ou mais perdas) é muito diferente - inocência e idealização já não existem mais. Há o medo do que pode vir a acontecer e, consequentemente, o medo de se vincular e perder. Será que é possível escolher não se vincular? Somos seres relacionais, propensos a construirmos ligações afetivas fortes com outros específicos (Bowlby, 2006) e necessitarmos delas do berço ao túmulo (Bowlby, 2002). É a partir das interações, antes mesmo do nascimento, que os vínculos começam a ser construídos. No desenvolvimento pré-natal, o bebê, ao fazer (ou não fazer) movimentos dentro do útero da mãe, já tem suas ações interpretadas por ela. Em contrapartida, o bebê também parece ser capaz de responder a alterações emocionais da mãe. Regulam-se assim, mãe e bebê, mesmo antes do nascimento. (Seidl-de Moura, 2009)

Perdas gestacionais e neonatais são comuns e frequentes, entretanto, o impacto na vida das famílias é sempre singular. Esse tipo de luto é, muitas vezes, vivido de maneira silenciosa pelas famílias que acabam não recebendo o suporte adequado, por não reconhecerem o tamanho e o significado da própria perda ou por uma não-validação da sociedade. Cala-se o luto de alguém que precisa vivê-lo para seguir.

Um dado importante da pesquisa foram as queixas e questionamentos em relação às instituições e equipes de saúde após a perda. A falta de empatia e acolhimento foram catalisadores de uma dor intensa. Por outro lado, o cuidado e a acolhida das equipes foram sentidos como extremamente significativos. Cabe, 
então, destacar a importância do treinamento das equipes e instituições não apenas em relação à estruturação e implementação de protocolos de comunicação, mas, especialmente, à sensibilização de todos em relação à necessidade de um cuidado compassivo que não cala, mas acolhe e respeita.

Algumas narrativas expressaram sentimento de incompetência, incapacidade e culpa. A culpa é uma resposta característica do luto e pode vir atrelada a pensamentos contrafactuais, sendo muito comuns os questionamentos e "e se". Tais pensamentos podem seguir por dois caminhos: possibilidade de construção de sentido e significado ou ruminação, que aponta para possíveis complicações do luto. Os pensamentos ruminatórios podem paralisar o enlutado e impedir o movimento oscilatório característico do luto propriamente dito.

Uma percepção importante durante a realização das entrevistas foi que as mães dedicaram a maior parte do tempo para falar sobre a perda e descrever os detalhes desse processo, assim como falar dos sentimentos e reações ligados à perda e ao luto. Parecia haver a necessidade de dar sentido ao vivido, mesmo quando a experiência havia ocorrido há muitos anos. Algumas disseram que nunca haviam falado de maneira tão organizada, apesar do contato com lembranças e sentimentos difíceis, sobre esse assunto. A dor que muitas vezes é silenciada não deixa de existir.

Por outro lado, as narrativas sobre as interações iniciais e construção de vínculo foram mais simplificadas e os relatos seguiam tendo o medo como característica importante. Medo do que poderia acontecer no momento do nascimento, medo de uma nova perda, medo de se separar do bebê... A dificuldade de se afastar do bebê ou de confiar no cuidado de outras pessoas foi mencionada diversas vezes durante as entrevistas. Dentre os sistemas parentais de Keller (2002), o contato corporal foi o mais mencionado pelas mães, que ressaltaram a importância de ter seus bebês junto a seus corpos como forma de proteção e cuidado, mas também como realização e concretização da existência dos filhos vivos.

Por fim, é importante destacar que o estudo não demonstrou que a chegada de um novo bebê "resolve" o processo de luto. O termo bebê arco-íris não apareceu de maneira significativa durante as entrevistas, o que reflete o desejo dos pais de darem um novo lugar para esses filhos. $\mathrm{O}$ medo foi um sentimento muito presente nas entrevistas e está evidenciado, pelos discursos, que não seria possível excluí-lo da relações mãe-bebê, especialmente após uma perda. É fundamental, entretanto, 
que o luto e suas respostas sejam integrados ao processo de vinculação de maneira que não impeçam a relação espontânea em que se confia na disponibilidade do outro em momentos de ameaça e medo, mas que também fomenta e possibilita a capacidade exploratória do indivíduo.

As limitações do estudo apontam para uma análise com mães em diferentes momentos, algumas já com bastante tempo transcorrido desde o nascimento do bebê após a perda. Outra limitação diz respeito a uma amostra composta em sua ampla maioria por mulheres em condições socioeconômicas semelhantes e com ensino superior completo. $\mathrm{O}$ fato de a pesquisa ter sido realizada durante a pandemia pela COVID-19 também pode ser considerado um elemento que limitou a investigação, especialmente pelo fato de nenhuma das entrevistas ter sido realizada presencialmente.

Acredita-se que o trabalho possa contribuir para demonstrar a importância da legitimação e do reconhecimento do luto por perda gestacional e neonatal pelos próprios enlutados, mas, especialmente, pela sociedade como um todo, para que as famílias recebam o cuidado adequado e, dessa forma, possam refletir com maior autonomia sobre a chegada de um novo bebê e sobre o papel desse filho em suas vidas. O vínculo entre cuidador primário e criança é fundamental para a sobrevivência física e emocional e, portanto, a atenção às interações iniciais é essencial no contexto das perdas perinatais. Sugere-se, ainda, que mais estudos sobre o tema sejam realizados para que medidas de intervenção e profilaxia possam ser implementadas. 


\section{Referências}

Ainsworth, M. (2015) Patterns of attachment: a psychological study of the strange situation. Nova York: Psychology Press.

Al, M. D. Y., Abujaradeh, H., Mahmoud, K. F., \& Jarrad, R. A. (2016). Maternal Grieving and the Perception of and Attachment to Children Born Subsequent to a Perinatal Loss. Infant Mental Health Journal, 37(4),411423. https://doi.org/10.1002/imhj.21570

Armstrong, D.S. (2002). Emotional distress and prenatal attachment in pregnancy after perinatal loss. Journal of Nursing Scholarship 34 (4), 339-345.

Attig, T. (2011) How we grieve - relearning the world. Nova York: Oxford University Press.)

Barbosa, A. (2016) Fazer o luto. Lisboa: Faculdade de Medicina da Universidade de Lisboa.

Bardin, L. (1977) Análise de conteúdo. Lisboa: Edições 70 Ltda.

Bowlby, J. (1944). Forty-five juvenile thieves: Their characters and home life. International Journal of Psycho-Analysis 21, 1-25.

Bowlby, J. (1988). A secure base: parent-child attachment and healthy human development. New York: Basic Books.

Bowlby, J. (2002). Apego e perda: apego (vol.1). São Paulo: Martins Fontes.

Bowlby, J. (2004). Apego e perda: perda (vol.3). São Paulo: Martins Fontes.

Bowlby, J. (2006). Formação e rompimento dos laços afetivos. São Paulo: Martins Fontes.

Bowlby, J., \& Parkes, C. M. (1970) Separation and loss within the family. In E. J. Anthony \& C. Koupernik (Eds.), The child in his family: International Yearbook of Child Psychiatry and Allied Professions (pp. 197-216). New York: Wiley.

Bussab, V.S.R. (2000) A família humana vista da perspectiva etológica: natureza ou cultura? Interação em Psicologia 4, 9-22.

Cain, A.C., \& Cain, B.S. (1964). On replacing a child. Journal of the American Academy of Child Psychiatry, 3, 443-456.

Camargo, B. V. \& Justo, A.M. (2013). IRAMUTEQ: um software gratuito para análise de dados textuais. Temas em Psicologia 21(2),513-518.

Casellato, G. (2015). Luto não reconhecido: o fracasso da empatia nos tempos modernos. In. Casellato, G. (Org.) O resgate da empatia: suporte psicológico ao luto não reconhecido. São Paulo: Summus.

Cassaday, T.M. (2018). Impact of pregnancy loss on psychological functioning and grief outcomes. Obstetrics and Gynecology Clinics of North America 45(3), 525-533. 
Cassidy, J. (2008) The nature of the child's tie. Em: Cassidy, J. e Shaver, P.R. (Eds.) Handbook of attachment: theory, research and clinical applications (pp. 222). Nova York: The Guilford Press.

Doka, K. J. (1989). Disenfranchised grief: recognizing hidden sorrow. Lexington: Lexington.

Doka, K.J. (2006) Thinking and planning for end of life: Rituals - How we cope with death and life. Exceptional Parent 36(7), 69-69.

Doka, K.J. (2008). Disenfranchised grief in historical and cultural perspective. In: Stroebe, M.S., Hansson, R.O., Schut, H. e Stroebe W. Handbook of bereavement research and practice: advances in theory and intervention (pp. 223-240). Washington: American Psychological Association.

Doka, K.J. (2016) Grief is a journey: finding your path through loss. Nova York: Atria Paperback.

Eisma, M., Epstude, K., Schut, H.A.W., Stroebe, M.S., Simion, A. \& Boelen, P.A. (2019) Upward and downward counterfactual thought after loss: a multiwave controlled longitudinal study. Behavior Therapy. Disponível em: https://doi.org/10.1016/j.beth.2020.07.007

Franco, M.H.P. (2010a). Famílias vivem seus lutos. In: L.A.B. Trad (Org.) Família contemporânea e saúde: significados, práticas e políticas públicas (pp. 371379). Rio de Janeiro: Ed. Fiocruz.

Franco, M.H.P. (2010b). Apresentação. In: Franco, M.H.P. (Org.) Formação e rompimento de vínculos: o dilema das perdas na atualidade (pp. 17-42). São Paulo: Summus.

Freud, E.L. (org.). (1982). Sigmund Freud: Correspondências de amor e outras cartas (1873-1939). Rio de Janeiro: Nova Fronteira.

Freud, S. (1996). Conferências introdutórias sobre psicanálise (Parte III). In: Edição Standard Brasileira das Obras Psicológicas Completas de Sigmund Freud (J. Salomão, trad., vol. XVI). Rio de Janeiro: Imago. (Trabalho original publicado em 1916).

Freud, S. (1996) Luto e Melancolia. In: Edição Standard Brasileira das Obras Psicológicas Completas de Sigmund Freud (J. Salomão, trad., vol. XV). Rio de Janeiro: Imago. (Trabalho original publicado em 1917).

Freud, S. (1996) Inibição, sintoma e angústia. In: Edição Standard Brasileira das Obras Psicológicas Completas de Sigmund Freud (J. Salomão, trad., vol. XX). Rio de Janeiro: Imago. (Trabalho original publicado em 1926).

Freud, S. (1996) Um esboço de psicanálise. In: Edição Standard Brasileira das Obras Psicológicas Completas de Sigmund Freud (J. Salomão, trad., vol. XXIII). Rio de Janeiro: Imago. (Trabalho original publicado em 1940).

Gaudet, C., Sejourne, N., Camborieux, L., Rogers, R., \& Chabrol, H. (2010). Pregnancy after perinatal loss: Association of grief, anxiety and attachment. Journal of Reproductive and Infant Psychology, 28, 240-251.

Glocker, M. L., Langleben, D.D., Ruparel, K., Loughead, J.W. \& Sachser, N. (2009). Baby Schema in Infant Faces Induces Cuteness Perception and Motivation for Caretaking in Adults. Ethology 115(3), 257-263. 
Green, M., \& Solnit, A.J. (1964). Reactions to the threatened loss of a child: A vulnerable child syndrome. Pediatrics, 34(1), 58-66.

Hughes, P., Turton, P., Hopper, E. \& Evans C.D.H. (2002) Assessment of guidelines for good practice in psychosocial care of mothers after stillbirth: a cohort study. Lancet 360(9327),114-118.

Keller, H. (2002) Development as the interface between biology and culture: a conceptualization of early ontogenetic experience. In Keller, H.; Poortinga, Y.H. \& Schölmerich, A. (Orgs.) Between culture and biology: perspectives on ontogenetic development (pp. 215-240). Cambridge: Cambridge University Press.

Klass, D., Silverman, P.R. \& Nickman, S.L. (Eds.) (1996). Continuing bonds: new understandings of grief. Washington DC: Taylor \& Francis.

Klass, D. \& Steffen, E.M. (Eds.) (2018). Continuing bonds in bereavement: new directions for research and practice. New York: Routledge.

Kübler-Ross, E. (1969). Sobre a morte e o morrer. São Paulo: Martins Fontes.

Lang, A., Fleiszer, A.R., Duhamel, F., Sword, W., Gilbert, K.R. \& Corsini-Munt, S. (2011). Perinatal loss and parental grief: the challenge of ambiguity and disenfranchised grief. Omega 63(2), 183-196.

Lindemann, E. (1944) The symptomatology and management of acute grief. The American Journal of Psychiatry 101(2), 141-148. Recuperado de: https://doi.org/10.1176/ajp.101.2.141

Lee, L., McKenzie-McHarg, K. \& Horsch, A. (2017) The impact of miscarriage and stillbirth on maternal-fetal relationships: an integrative review. Journal of Reproductive and Infant Psychology, 35(1), 32-52.

Lee, L., McKenzie-McHarg, K., \& Horsch, A. (2013). Women's decision making and experience of subsequent pregnancy following stillbirth. Journal of Midwifery \&Women's Health, 58, 431-439.

Mendonça, C.S.A. (2018). Interrupção espontânea da garvidez, morte fetal e perda perinatal: luto e fatores protetores. Dissertação de Mestrado, Unversidade de Lisboa, Lisboa, Portugal.

Mitima-Verloop, H.B., Mooren, T.T.M. \& Boelen, P.A. (2019). Facilitating grief: na exploration of the function of funerals and rituals in relation to grief reactions. Death Studies, 1-11.

Neimeyer, R.A. (1999). Narrative strategies in grief therapy. Journal of Constructivist Psychology 12, 65-85.

Neimeyer, R.A (2002). Meaning reconstruction and loss. In: Neimeyer, R.A. (ed) Meaning reconstruction and the experience of loss (pp. 1-9). Washington: American Psychological Association.

Neimeyer, R.A, Klass, D. \& Dennis, M.R. (2014). A Social Constructionist Account of Grief: Loss and the Narration of Meaning. Death Studies 38, 485-498.

Oliveira, M.T.S., Oliveira, C.N.T., Marques, L.M. L, Souza, C.L., \& Oliveira, M.V. (2020). Fatores associados ao aborto espontâneo: uma revisão sistemática. Revista Brasileira de Saúde Materno Infantil, 20(2), 361-372 
Parkes, C.M. (1971) Psycho-social transitions: A field for study. Social Science \& Medicine, 5(2), 101-115. Recuperado de: https://doi.org/10.1016/00377856(71)90091-6.

Parkes, C.M. (1998). Luto - estudos sobre a perda na vida adulta. São Paulo: Summus. 1998.

Parkes, C.M. (2009). Amor e perda - as raízes do luto e suas complicações. São Paulo: Summus.

Rato, P. (1998). Ansiedades perinatais em mulheres com gravidez de risco e em mulheres com gravidez normal. Análise Psicológica, 3 (XVI), 405-413.

Reid, M. (2007). The loss of a baby and the birth of the next infant: The mother's experience. Journal of Child Psychoterapy 33 (2), 181-201.

Salgado, H.O \& Polido, C.B.A. (2018). Como lidar luto perinatal: acolhimento em situações de perda gestacional e neonatal. São Paulo: Ema Livros.

Seidl-de-Moura, M.L. (2009). Interações sociais e desenvolvimento. In: Seidl-deMoura, M.L.; Mendes, D.M.L.F.; Pessôa, L.F. (Orgs.) Interação social e desenvolvimento (pp. 19-36). Curitiba: Editora CRV.

Stroebe, M. \& Schut, H. (1999). The dual process model of coping with bereavement: rationale and description. Death Studies 23, 197-224.

Stroebe, M. \& Schut, H. (2001) Meaning making in the dual process model of coping with bereavement. In: Neimeyer, R. (ed.) Meaning reconstruction and the experience of loss (pp. 55-73). Washington: American Psychological Association.

Stroebe, M., Stroebe, W., van de Schoot, R., Schut, H., Abakoumkin, G. \& Li, J. (2014) Guilt in Bereavement: The Role of Self-Blame and Regret in Coping with Loss. PLoS One 9(5), 1-9.

Tavares, A.C.S. (2013) Lutos gestacional e neonatal: vivência subjectiva materna da perda. Dissertação de Mestrado. ISPA - Instituto Universitário, Lisboa, Portugal.

Theut, S.K., Pedersen, F.A., Zaslow, M.J., Cain, R.L., Rabinovich, B.A. \& Morihisa, J.M. (1989). Perinatal loss and parental bereavement. American Journal of Psychiatry 146, 635-639.

Üstündağ-Budak A.M., Larkin, M., Harris, G. \& Blissett, J. (2015) Mothers' accounts of their stillbirth experiences and of their subsequent relationships with their living infant: na interpretative phenomenological analysis. $B M C$ Pregnancy and Childbirth 152(263), 1-14.

Vicente, C.C. (2009). Apego e desenvolvimento. In: Seidl-de-Moura, M.L.; Mendes, D.M.L.F.; Pessôa, L.F. (Orgs.) Interação social e desenvolvimento (pp.87-100). Curitiba: Editora CRV.

Volkmer V.P. (2016). Trajetórias interrompidas: perdas gestacionais, luto e reparação. Salvador: EDUFBA.

Volkmer, V. P. (2009). Significados de maternidade para mulheres com trajetória reprodutiva marcada por perdas gestacionais recorrentes. Dissertação de Mestrado. Universidade Federal da Bahia, Salvador, BA. 
Walsh, F. \& McGoldrick, M. (1998). Morte na família: Sobrevivendo às perdas. Porto Alegre: Artes Médicas.

Worden, J.W. (2013). Terapia no luto e na perda: um manual para profissionais de saúde mental. São Paulo: Roca. 


\section{Anexo I}

\section{Roteiro semiestruturado de entrevista}

1. Como aconteceu a perda do seu bebê?

2. Como você vivenciou o seu processo de luto?

3. Quando você começou a pensar em engravidar novamente?

4. Como foi receber a notícia de que você estava grávida?

5. Como foi o seu período de gestação do novo bebê?

6. Como foi o nascimento e os primeiros meses desse bebê?

7. Como foram as primeiras interações estabelecidas com o seu bebê?

8. Houve alguma transformação na sua vida após a chegada do bebê?

9. Como tem sido a sua rotina atual com seu filho (a)? 


\section{Anexo II}

\section{TERMO DE CONSENTIMENTO LIVRE E ESCLARECIDO}

TÍTULO: Perda gestacional e neonatal: um estudo sobre luto e vínculo.

OBJETIVOS DO ESTUDO: Investigar as repercussões da perda gestacional ou neonatal prévia no processo de construção do vínculo da mãe com o bebê que nasce durante o processo de luto.

ALTERNATIVA PARA PARTICIPAÇÃO NO ESTUDO: Para participar do estudo você não terá nenhum custo, nem receberá qualquer vantagem financeira. Você tem plena liberdade de recusar-se a participar da pesquisa, em qualquer fase, sem necessidade de comunicado prévio. A sua participação é voluntária e a recusa em participar não acarretará qualquer penalidade ou modificação na forma como você é atendido pela pesquisadora. Os resultados da pesquisa estarão à sua disposição quando finalizada. Você não será identificado(a) em nenhuma publicação em que possa resultar o estudo. Seu nome ou o material que indique sua participação não serão liberados sem a sua permissão.

PROCEDIMENTO DO ESTUDO: Se você decidir participar deste estudo, você responderá a uma entrevista, presencialmente, no local em que se sentir mais confortável, ou por Skype, com duração de aproximadamente 30 minutos. Os resultados obtidos serão sempre apresentados como um todo, sem revelar sua identidade ou qualquer informação que esteja relacionada à sua privacidade.

RISCOS: Você pode achar que algumas informações são pessoais, caso ocorra você poderá escolher não responder. Esta pesquisa envolve riscos mínimos de acordo com a resolução 510/16. Caso você sinta desconforto, você poderá solicitar ajuda e será acolhido(a) pela pesquisadora e, se houver necessidade, poderá ser encaminhado à profissionais adequados.

BENEFÍCIOS: Ao participar desta pesquisa você estará colaborando com um estudo sobre a compreensão dos impactos do luto advindo de perda gestacional ou neonatal sobre a mãe e suas repercussões no desenvolvimento do vínculo com o novo bebê, além de possibilitar a construção e implementação de estratégias que possam prevenir possíveis complicações e que promovam saúde na relação mãebebê. 
CONFIDENCIALIDADE: Como foi dito acima, seu nome não aparecerá em nenhum formulário a ser preenchido pela pesquisadora. Nenhuma publicação partindo destas entrevistas revelará os nomes de quaisquer participantes da pesquisa. A pesquisadora não divulgará nenhum dado de pesquisa no qual você seja identificado(a), utilizando as informações somente para fins científicos.

No caso do não cumprimento, há liberdade de retirar esta anuência a qualquer momento sem incorrer em penalização alguma.

DÚVIDAS E RECLAMAÇÕES: Esta pesquisa possui vínculo com a Pontifícia Universidade Católica do Rio de Janeiro através do Programa de Pós-Graduação em Psicologia, sendo Cecilia Rezende da Silva Cunha a pesquisadora principal, sob a orientação da $\operatorname{Prof}^{a}$ Luciana Fontes Pessôa, contatos: e-mail: luciana_pessoa@puc-rio.br e telefone: 3527-1183. A pesquisadora está disponível para responder a qualquer dúvida que você tenha. Caso seja necessário, contate-a no telefone (21) 982039357 ou e-mail rezende.cecilia@gmail.com. Você também poderá contatar o Comitê de ética em pesquisa da Pontifícia Universidade Católica do Rio de Janeiro através do telefone: (21) 3527.1618 e do endereço: Rua Marquês de São Vicente, 225 - Edifício Kennedy, $2^{\circ}$ andar. Gávea, Rio de Janeiro, RJ. CEP: 22453-900.

FONTE DE FINANCIAMENTO: A fonte de financiamento da pesquisa é a bolsa oferecida pela Vice-Reitoria Acadêmica da Pontifícia Universidade Católica do Rio de Janeiro.

Esse termo de consentimento deverá ser assinado em duas vias. Você receberá uma via deste consentimento para guardar com você. Você fornecerá nome, endereço e telefone de contato apenas para que a equipe do estudo possa lhe contatar, em caso de necessidade. 
$\mathrm{Eu}$, concordo em participar deste estudo.

Assinatura:

Data:

Endereço:

Telefone

de

contato:

Assinatura

(Pesquisadora):

Nome:

Data:

1 1

Departamento de Psicologia

Rua Marquês de São Vicente, 225, Sala 201L - Gávea - CEP· 22543-900

Rio de Janeiro - RJ - Tel. (021) / 3527.1001 / 3527.2286

E-mail:psipos@puc-rio.br 